Andrews University

Digital Commons @ Andrews University

2014

\title{
Mentoring and Discipling the Early Adolescents of the Kitchener- Waterloo Seventh-day Adventist Church
}

Jiwan S. Moon

Andrews University

Follow this and additional works at: https://digitalcommons.andrews.edu/dmin

Part of the Practical Theology Commons

\section{Recommended Citation}

Moon, Jiwan S., "Mentoring and Discipling the Early Adolescents of the Kitchener-Waterloo Seventh-day Adventist Church" (2014). Professional Dissertations DMin. 87.

https://dx.doi.org/10.32597/dmin/87

https://digitalcommons.andrews.edu/dmin/87

This Project Report is brought to you for free and open access by the Graduate Research at Digital Commons @ Andrews University. It has been accepted for inclusion in Professional Dissertations DMin by an authorized administrator of Digital Commons @ Andrews University. For more information, please contact repository@andrews.edu. 


\begin{abstract}
MENTORING AND DISCIPLING THE EARLY ADOLESCENTS OF THE KITCHENER-WATERLOO SEVENTH-DAY ADVENTIST CHURCH
\end{abstract}

by

Jiwan Stefan Moon

Adviser: Barry Gane 


\section{ABSTRACT OF GRADUATE STUDENT RESEARCH \\ Project Document}

Andrews University

Seventh-day Adventist Theological Seminary

Title: MENTORING AND DISCIPLING THE EARLY ADOLESCENTS OF THE KITCHENER-WATERLOO SEVENTH-DAY ADVENTIST CHURCH

Name of researcher: Jiwan Stefan Moon

Name and degree of adviser: Alva Barry Gane, PhD

Date Completed: April 2014

\section{Problem}

From 1951 to 2001, at the Kitchener-Waterloo Seventh-day Adventist Church, only one family from the founding generation has its children and grandchildren attending and active in the church. Most of the second and third generation members of the church who once attended, no longer practice their inherited Adventist religious beliefs. As the church membership was aging, the church was dying and membership continued to decrease, especially the number of young people. It was becoming evident that the church needed intervention to prevent continuous loss of members. In order to prevent a repeat of history, there was a need for an intentional mentoring and discipleship program/process for young people in the church, especially the early adolescents. 


\section{Method}

After four years of intentional ministry for the young people of the church from September 2002 to December 2005 in laying the foundation for successful children's ministries and youth and young adult ministry, both long-term ( 7 years) and short-term ( 7 months) mentoring and discipleship program/process were introduced and implemented from 2006 to 2012 and from March to September 2013. The mentoring and discipleship program/process involved the early adolescents in service and mission projects and church events, in the regular presence of a mentor (the researcher) who, modeled the Christian identity, living Christ's self-renouncing and self-sacrificing love by teaching them the missionary spirit of selfless Christian service for God and others.

\section{Results}

The overall retention rate of the young people of the church since the mentoring program/process began is $90 \%$, and the retention rate of the young people who were involved and participated in at least three of the six mission trips of the last 6 years and who have gone through over 3 years of a seven-year intentional mentoring and discipleship program/process during their adolescence is $100 \%$. These adolescents are all attending the church faithfully and are actively serving in different ministries of the church.

\section{Conclusion}

The influence of a Christian mentor who teaches and exhibits true Christ-like character is essential in an early adolescent's faith development. 
Mentoring and discipleship of early adolescents is necessary to keep young people in the church and to help them become proactive in their Christian faith, living a life of selfrenouncing and self-sacrificing love, resulting in selfless Christian service. 
Andrews University

Seventh-day Adventist Theological Seminary

MENTORING AND DISCIPLING THE EARLY ADOLESCENTS OF THE KITCHENER-WATERLOO SEVENTH-DAY ADVENTIST CHURCH

\author{
A Project Document \\ Presented in Partial Fulfillment \\ of the Requirements for the Degree \\ Doctor of Ministry
}

by

Jiwan S. Moon

April 2014 
(C) Copyright by Jiwan S. Moon 2014 All Rights Reserved 
MENTORING AND DISCIPLING THE EARLY ADOLESCENTS OF THE

\title{
KITCHENER-WATERLOO SEVENTH-DAY ADVENTIST CHURCH
}

\author{
A project document \\ presented in partial fulfillment \\ of the requirements for the degree \\ Doctor of Ministry
}

by

Jiwan S. Moon

APPROVAL BY THE COMMITTEE:
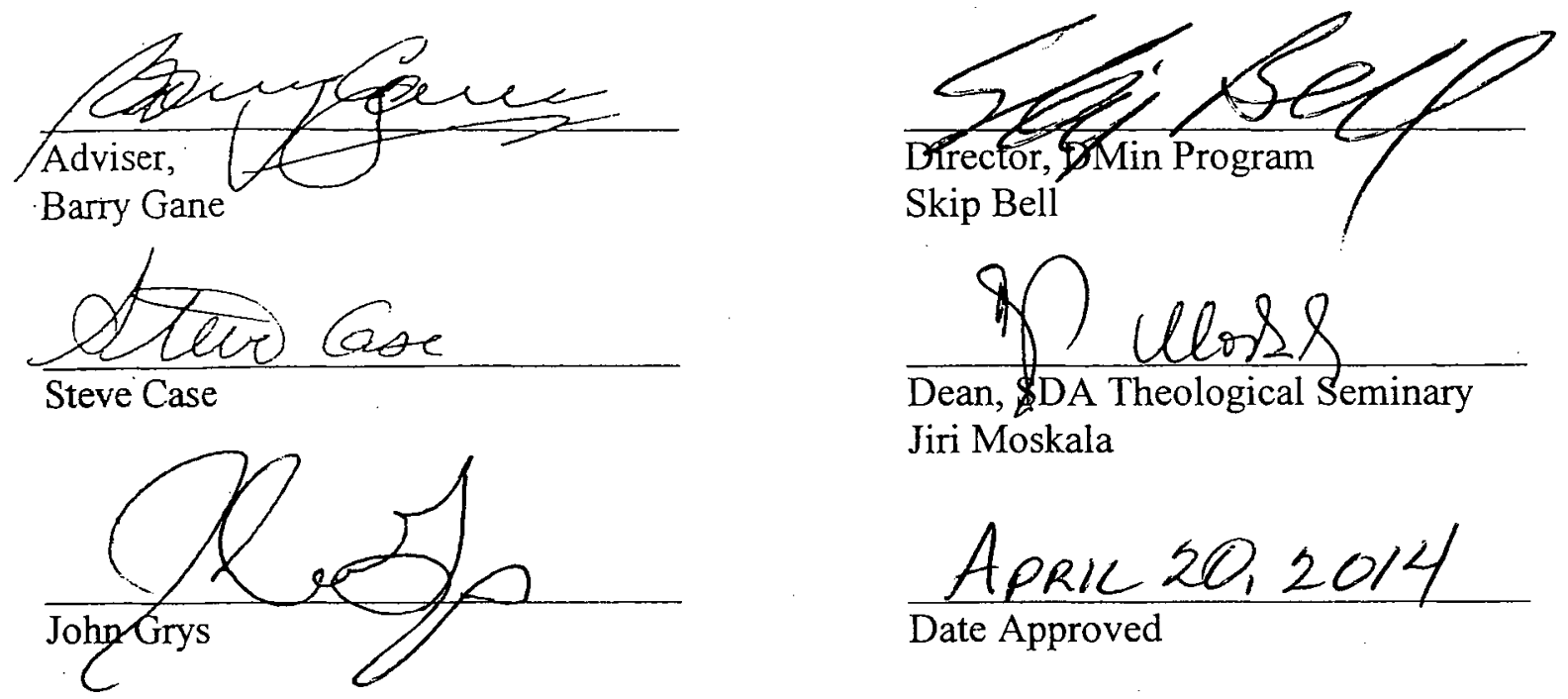

Jiri Moskala

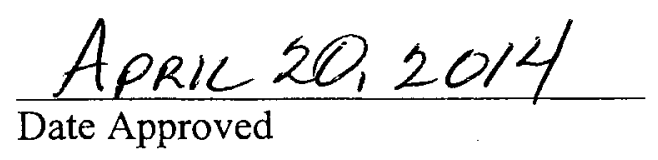




\section{DEDICATION}

\section{Dedicated to}

my father Dr. Young Suk Moon for being the mentor of my life/ministry; to my mother Chul Joo Moon for praying for me without ceasing;

to Dr. Barry Gane for his 15 years of mentoring;

to my most precious daughters

Hannah Moon,

Rebecca Anna Moon, and Isabella Jinah Moon;

to my beloved wife Jessica Moon

who fills all that I lack and completes me.

Without you, I would not have been able to finish

this journey that helped me to realize even more the importance of mentoring and discipling young people for Christ. 


\section{TABLE OF CONTENTS}

LIST OF ABBREVIATIONS ...................................................................... xi

ACKNOWLEDGEMENTS ..................................................................... xii

\section{Chapter}

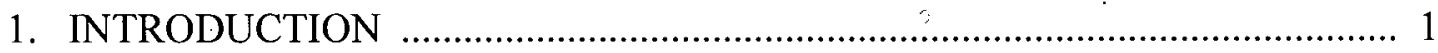

Description of the Ministry Context ………………..................................... 1

Statement of the Problem ............................................................................. 1

Statement of the Task ..................................................................................... 2

Expectations From the Project .................................................................... 3

Significance of the Project .............................................................................. 3

Description of the Project Process .................................................................... 4

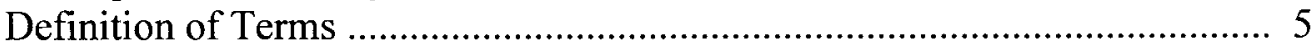

\section{A THEOLOGICAL BASIS FOR EARLY ADOLESCENT} MENTORING AND DISCIPLESHIP .................................................... 7

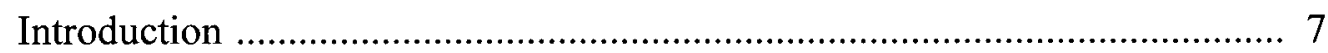

Early Adolescents in the Bible ..................................................................... 7

A Scriptural View of Childhood and Adolescence ……......................... 8

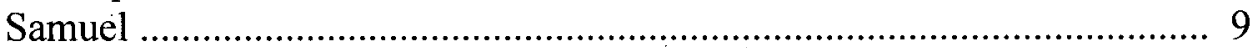

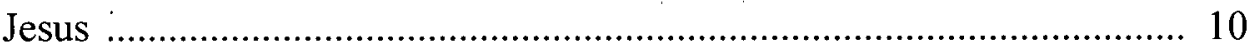

Theological Foundation for Mentoring and Discipleship .............................' 11

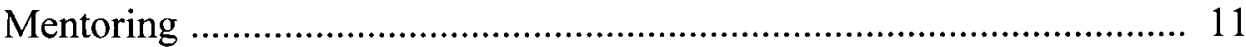

Definitions of Mentor and Mentoring ………………...................... 11

A Biblical Definition .................................................................... 12

Discipleship .................................................................................. 13

"Come, Follow Me"-Jesus' Model of Mentoring and Discipleship .... 14

Historical and Cultural Background ................................................. 14

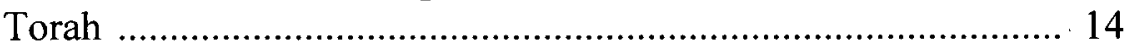

Bet Sefer and Bet Talmud .................................................... 15

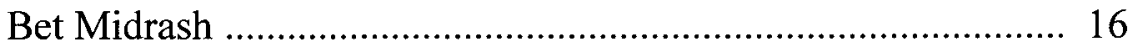

Rabbi Jesus_Jesus the Teacher ............................................... 17

Adolescent Identity ................................................................. 19

The Biblical Mentor and Discipler .................................................. 21

Jesus the Mentor and the Discipler of Adolescents ......................... 23 
Come, Follow Me —Jesus' Mentoring and Discipleship ....................... 25

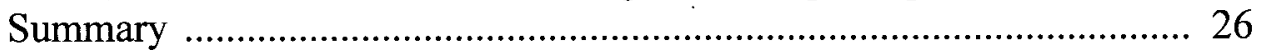

Biblical Examples for Mentoring/Discipleship ............................................. 27

Old Testament Examples of Mentoring/Discipleship ............................ 27

Jethro and Moses .......................................................................... 27

Moses, Joshua and Caleb ............................................................ 27

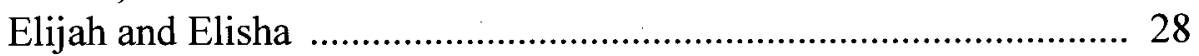

New Testament Examples of Mentoring/Discipleship ........................... 29

Barnabas and Paul .................................................................... 29

Priscilla, Aquila and Apollos ...................................................... 30

Paul, Timothy and Titus ............................................................ 30

Jesus, the Disciples and Mary Magdalene ………………………... 31

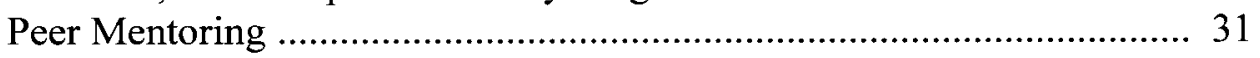

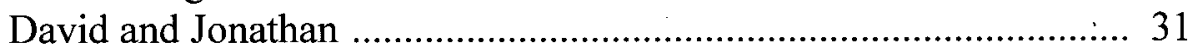

Biblical Examples for Early Adolescent Mentoring and Discipleship ......... 32

Jochebed and Moses ............................................................................. 32

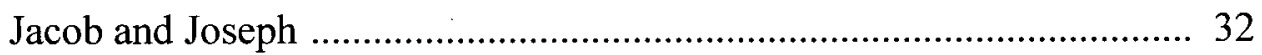

Samuel and Eli ................................................................................ 33

Elijah and the Widow's son .............................................................. 34

Elisha and the Shunammite's son ...................................................... 34

Lois and Eunice with Timothy ................................................................ 35

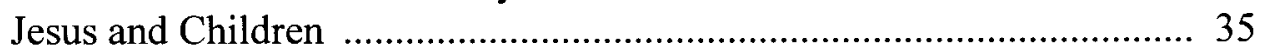

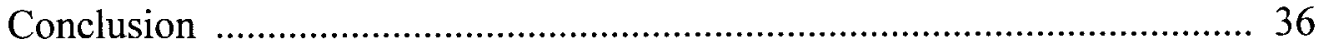

\section{LITERATURE REVIEW ON EARLY ADOLESCENT}

MENTORING AND DISCIPLESHIP ................................................ 38

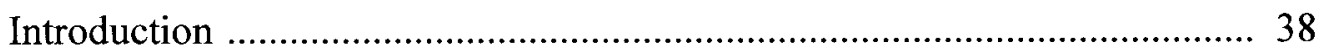

Early Adolescence ……………………………….............................. 39

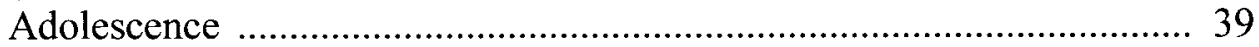

Early Adolescent Years ......................................................................... 40

When Does Early Adolescence Begin? ........................................... 40

When Does Early Adolescence End? ………………….................. 42

Changes and Transitions in Early Adolescence ...................................... 42

Biological and Physiological Changes

and Physical Development-Puberty ........................................... 43

Puberty .............................................................................. 43

Brain Development ............................................................... 44

Academic Changes and Transitions ................................................ 45

Social, Sexual and Psychological Changes ...................................... 46

Cognitive Development .............................................................. 47

Spiritual Development ............................................................... 48

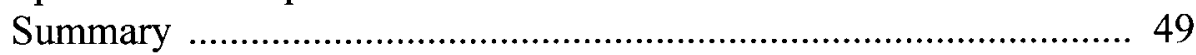

Early Adolescence Theories and Spirituality ................................................ 49

Developmental Theories of Early Adolescence ..................................... 50

Piaget's Stages of Cognitive Development Theory .......................... 50 
Vygotsky's Sociocultural Theory …………………..................... 52

Information-Processing Theories .................................................... 55

Anna Freud's Psychological Theory ................................................. 56

Piaget's Moral Development Theory ............................................. 57

Kohlberg's Moral Development Theory ........................................ 58

Gilligan's Theory of Gender Differences in Morality Reasoning .... 60

Kegan's Constructive Development Theory ....................................... 61

Erikson's Theory—Identity and Period of Moratorium ................... 62

James Marcia's Identity Status Theory ………………...................... 65

James Fowler's Theory—Stages of Faith ………………………..... 65

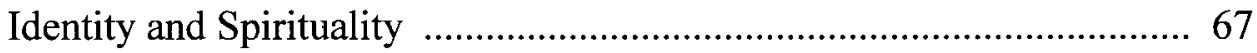

Early Adolescence Mentoring and Discipleship ........................................... 68

Parent Mentoring ……................................................................. 70

Non-Parent Mentoring/Discipleship .................................................. 72

Peer Mentoring ……..................................................................... 75

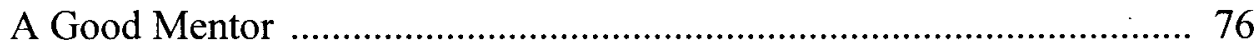

Early Adolescents Mentoring and Discipleship …………….................. 77

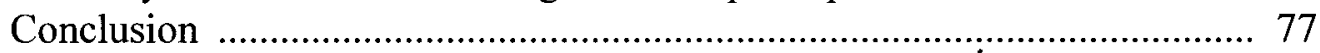

\section{PROJECT DEVELOPMENT AND NARRATIVE}

OF PROJECT IMPLEMENTATION _.................................................... 79

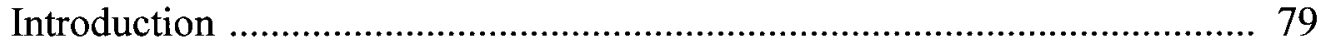

Kitchener-Waterloo Seventh-day Adventist Church ................................... 80

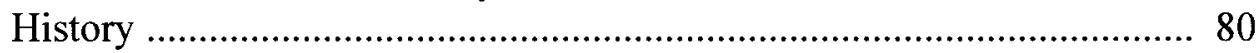

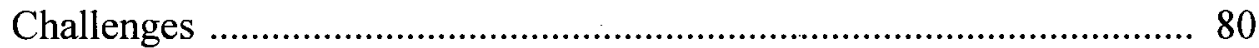

Change in Youth Ministry Approach .................................................. 81

Observation and Intervention-Laying the Youth Ministry Foundation ..... 82

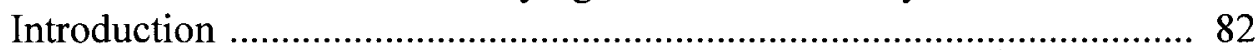

First Year of Intentional Ministry ................................................... 83

September 2002-December 2002 .............................................. 83

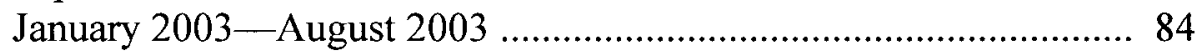

Second Year of Intentional Ministry .................................................... 84

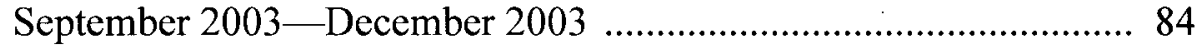

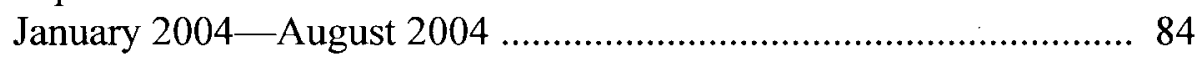

Third Year of Intentional Ministry ………………………………….... 86

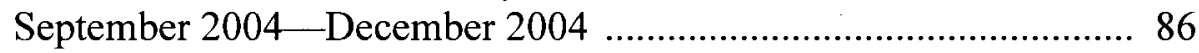

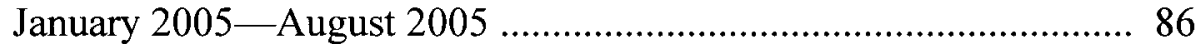

Fourth Year of Intentional Ministry ...................................................... 87

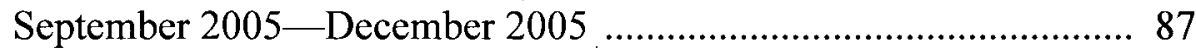

Evaluation and Implementation - Mentoring and Discipleship ................... 88

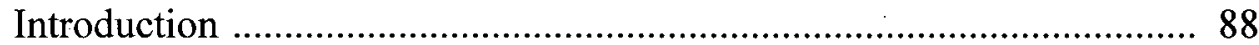

First Year of Intentional Mentoring and Discipleship - Year 2006 ....... 89

Objectives for Early Adolescent Mentoring and Discipleship ......... 89

Continuing Active Youth and Young Adult Ministry ..................... 90

Second Year of Intentional Mentoring and Discipleship_-Year 2007 ... 91 
Major Challenge Faced-Cultural Conflict and Clash ........................... 91

Cultivating Missionary Spirit and the Missionaries .......................... 92

Children's Evangelistic Series ........................................................ 93

Third Year of Intentional Mentoring and Discipleship_-Year 2008 ...... 95

Mentoring and Discipleship for Evangelism and Witnessing ........... 95

Peer Mentoring-FNL (Friday Night Live) .................................... 96

Empowered to Serve and Evangelize ..................................................... 97

Fourth Year of Intentional Mentoring and Discipleship — Year 2009 .... 97

Instilling the True Christian Identity-

Living Self-Sacrificing Love ......................................................... 97

ROCMM-Reach-Out \& Care Missionary Movement .................... 97

Building Partnership with Other Mentors ...................................... 98

Essence of Early Adolescent Mentoring and Discipleship .............. 98

Fifth Year of Intentional Mentoring and Discipleship-Year 2010 ...... 99

Identity Installation and Preservation ............................................ 99

Pathfinders and Adventist Identity ................................................ 99

Positive Peer Influence ............................................................. 100

Practicing Jesus Christ's Self-Renouncing

and Self-Sacrificing Love ....................................................... 100

Sixth Year of Intentional Mentoring and Discipleship_-Year $2011 \quad \ldots \quad 101$

Living the Missionary Spirit ......................................................... 101

Youth Missionaries Being Mentored

and Mentoring Other Youths ...................................................... 101

Keeping the Missionary Spirit Afresh and Alive ............................ 102

Project/Seventh Year of Intentional Mentoring

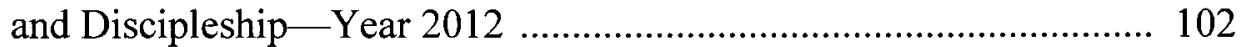

Objectives for the Short-term Project ......................................... 102

Rationale and Preparation for Early Adolescent

Mentoring and Discipleship ........................................................ 103

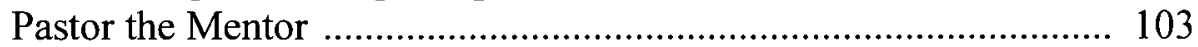

Project Implementation .............................................................. 104

Follow Me Adventist Movement Facebook Group ....................... 104

Follow Me Silent Service Flash Mob ........................................... 105

ROCMM Mission Trip to Lindsay ............................................... 105

“Once a Missionary, Always a Missionary!" ................................. 106

Mentor's Presence ................................................................... 106

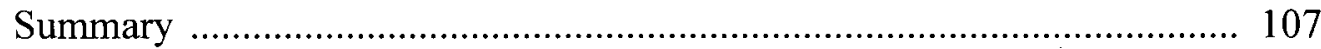

5. EVALUATION AND OUTCOMES …...................................................... 108

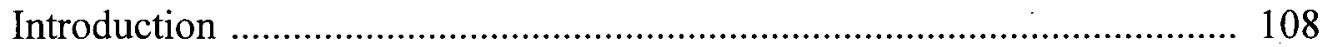

Adolescent Choices and Decisions ........................................................ 108

Early Adolescent Choices and Decisions ........................................ 109

Early and Middle Adolescents Choices and Decisions ....................... 109

Late Adolescents Choices and Decisions ........................................... 110

Group Observation ..................................................................... 110 
Early Adolescent Choices and Decisions .................................................. 111

Early Adolescent Boys Choices/Decisions .......................................... 111

Early Adolescent Girls Choices/Decisions ........................................... 112

Secrets of Adolescents and Perception of Early Adolescents' Parents ....... 112

Early Adolescents' Response .......................................................... 113

Perception of Early Adolescents' Parents ........................................... 113

Summary ....................................................................................... 114

Challenges of Mentoring/Parenting Early Adolescent ............................. 115

Parents' Perspective of Early Adolescents' Choices and Decisions ..... 115

Parents' Challenges With Early Adolescent Behaviors ......................... 116

Choices and Decisions for Early Adolescents' Spiritual Growth ............... 116

Positive Choices/Decisions for Early Adolescents' Spirituality ........... 116

Choices/Decisions Positively Impacted

Early Adolescents' Spirituality …………………........................... 117

An Observation ......................................................................... 117

Intentional Early Adolescent Ministry That Made a Difference ................ 117

Parents' Evaluations and Observations .............................................. 118

Early Adolescents' Responses/Reflections and Observations .............. 118

Reflection Questions ................................................................ 119

Early Adolescents' Response and Reflections .............................. 119

Secrecy and Privacy of Early Adolescents .............................. 119

Early Adolescents' Sense of Closeness to God,

Before and After the Short-Term Project ................................ 120

Mission Trip, FNL, Pathfinder Club, and Bible Classes .......... 121

Individual Experiences and Personal Responses ........................... 122

Early Adolescents' Suggestions to the Church

To Help Them Feel Closer to God ............................................... 123

Go-To-People for Early Adolescents of the Church ....................... 124

Go-To-People for Early Adolescents Other Than Parents .............. 125

Who can Early Adolescents go to? ………………….................... 125

Personal Observations .............................................................. 126

Intended Objectives for Intentional Ministry

and Mentoring and Discipleship .......................................................... 127

Notable Findings and Outcomes ........................................................... 128

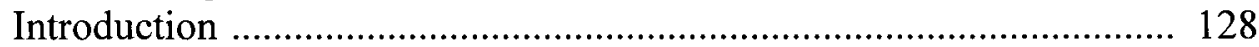

Early Adolescents are Making Serious Life Choices Early on ............ 129

Making Positive Choices Resulted in Spiritual Growth ....................... 130

Early Adolescents Noticed and Felt Mentor's Presence ....................... 131

Adolescents and Early Adolescents Need

Both Mentors and Peer-Mentors .................................................... 131

Mentoring and Discipleship are Processes not Events ........................ 133

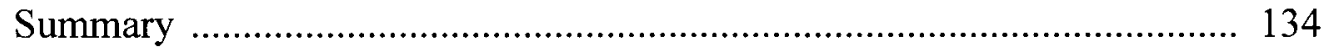

6. SUMMARY, CONCLUSION, AND RECOMMENDATION ....................... 138

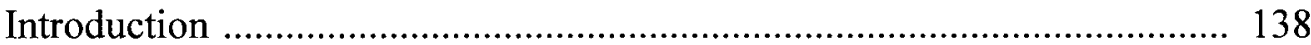




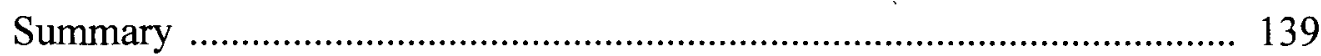

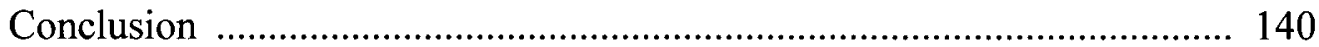

Rethinking Youth Ministry ….......................................................... 141

When Does Youth Ministry Begin? ............................................... 141

New Trend in Youth Ministry ............................................................ 141

The Beginning of Youth Ministry Overlaps

With the end of Children's Ministries .............................................. 142

The Continuum of Youth Ministry ..................................................... 143

Importance of Early Adolescent Mentoring and Discipleship .............. 144

The FOLLOW ME_Jesus' Mentoring and Discipleship Model ........ 144

Five Adolescent Faith/Spiritual Developmental Stages ....................... 144

Stage 1-Passive/Inactive Faith Stage ........................................... 145

Stage 2-Reactive Faith Stage ..................................................... 145

Stage 3-Reflective Faith Stage ………………….................... 145

Stage 4-Active Faith Stage ....................................................... 146

Stage 5-Proactive Faith Stage …………………….................... 146

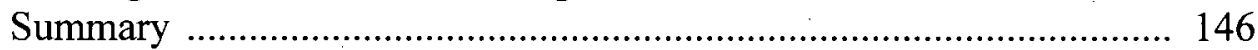

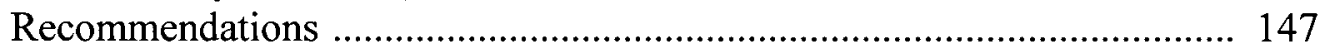

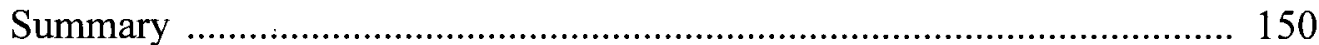

Appendix

A. THE FOLLOW ME JESUS' MENTORING \& DISCIPLESHIP MODEL ..... 154

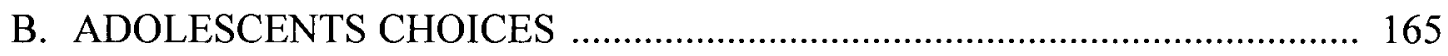

C. EARLY ADOLESCENT MALES' CHOICES ………………..................... 166

D. EARLY ADOLESCENT FEMALES' CHOICES ……………...................... 167

E. EARLY ADOLESCENT FEMALES' PARENTS' RESPONSES ................... 1.68

F. EARLY ADOLESCENTS' \& ADOLESCENT'S PARENTS' RESPONSES

G. EARLY ADOLESCENT MALES' PARENTS' RESPONSES ….................. 170

H. MOON'S FAITH DEVELOPMENTAL STAGES ...................................... 171

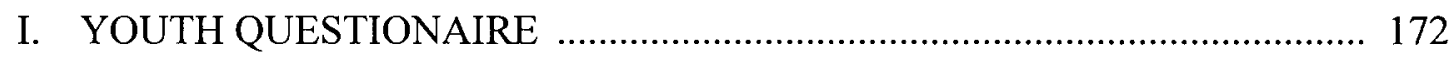

J. INFORMED ASSENT/CONSENT FOR PARTICIPATION IN RESEARCH PROJECT ................................................................ 173

K. FOLLOW ME ADVENTIST MOVEMENT ………………........................ 175 
REFERENCE LIST

VITA 


\section{LIST OF ABBREVIATIONS}

ADRA

AMiCUS

AY

CYMAC

FMAM

FMSSFM

FNL

JAY

K-WAY

KWSDAC

NMSA

ROCMM

ROMM

SDA

SDACC

VBS

WACA
Adventist Development and Relief Agency

Adventist Ministry to College and University Students Adventist Youth

Children and Youth Ministry Advisory Committee

Follow Me Adventist Movement

Follow Me Silent Service Flash Mob

Friday Night Live

Junior Adventist Youth

Kitchener-Waterloo Adventist Youth

Kitchener-Waterloo Seventh-day Adventist Church

National Middle School Association

Reach-Out \& Care Missionary Movement

Reach-Out Missionary Movement

Seventh-day Adventist Church

Seventh-day Adventist Church in Canada

Vacation Bible School

Waterloo Adventist Christians Association 


\section{ACKNOWLEDGEMENTS}

I thank Dr. Barry Gane, my adviser who always encouraged, motivated, and mentored me when I needed him the most. Without his understanding, encouragement and support, I would not have been able to finish my study.

I thank Dr. Steve Case for his mentoring and his insightful suggestions that improved my project document. His expertise in youth and young adult ministry not only challenged me to work extra hard for this project, but provided some resources that enriched my study.

I thank the Kitchener-Waterloo Seventh-day Adventist Church Family for their love and care extended to me and my family. The last 11 years have been the best part of our lives.

I thank the youths and the young adults of the Kitchener-Waterloo Seventh-day Adventist Church who are the reason for my decade long period of mentorship and discipleship.

I thank God and give Him all the glory and honor for He is good and merciful and His love endures forever!

I thank Jesus for His amazing grace, His self-renouncing and self-sacrificing love, and His selfless service and sacrifice that inspire me every moment of my life!

Thank you Jesus for being the Mentor of my life! 


\section{CHAPTER 1}

\section{INTRODUCTION}

\section{Description of the Ministry Context}

Many churches are feeling the effects of what some call "The Silent Exodus," that is, young people leaving the church almost imperceptibly, while at the same time the churches are struggling to keep their doors open due to an aging population and decreasing membership that contribute to declining financial stability. As churches continue to face challenges in retaining their members, especially young people, future prospects of the churches are bleak, thus threatening the effectiveness of the Gospel ministry. This project will address one of the main challenges of churches, the disappearance of the youth. It will introduce information and resources that will help enhance youth and young adult ministry and provide effective ways to not only retain the young people, but also help them to become proactive Christians. Also presented are intentional thinking and approaches in youth ministry that will give notice that youth ministry really begins when their (the youth) involvement in children's ministry is coming to an end, which is much sooner than we think.

\section{Statement of the Problem}

From 1951 to 2001, at the Kitchener-Waterloo Seventh-day Adventist Church (KWSDAC), only one family from the founding generation has its children and 
grandchildren attending and active in the church. Most of the second and third generation members of the church, who once attended, no longer do and neither do they practice their inherited Adventist religious beliefs. One of the reasons for this is due to a lack of a mentoring and discipleship program for early adolescents in our churches that will help to bridge the gap and provide nurturing and stability during the adolescent years, the time of great searching in their lives. We watch carefully over our toddlers and adventurers, but we tend to lose touch with our adolescents as they leave our churches in scores.

Nevertheless, from 2002 to 2013, KWSDAC effected a reversal in this trend and caused an increase in the attendance of young families at the church, resulting in the swell of young children, youth and young adults. In order to prevent a return to this situation, there is a need for an intentional mentoring and discipleship program for current young adolescents in the church.

\section{Statement of the Task}

The task of this project is to develop and implement a mentoring and discipleship program/process for early adolescents in the Kitchener-Waterloo Seventh-day Adventist Church. The project will be evaluated to determine the impact of the intentional mentoring and discipleship program on the early adolescents by measuring the increase in the level of their involvement in service activities and also by measuring their perceived closeness to God through a questionnaire survey. 


\section{Expectations From the Project}

This project should increase the early adolescents' level of involvement in service activities and their perceived closeness to God. It also should increase awareness of the importance of early adolescent mentoring and discipleship and early adolescent ministry.

Furthermore, it should provide another youth ministry model for early adolescent ministry and should provide relevant information and resources to educate and equip youth and young adult ministry professionals as well as leaders, administrators, and workers at all levels of the General Conference of the Seventh-day Adventist Church, so that they will create a similar adolescent ministry in their respective organizations, fields, and local churches.

\section{Significance of the Project}

Given the fact that youth ministry traditionally has focused more on high school students and older, there has not been much research or study done targeting and focusing solely on younger youth, specifically, early adolescents between the ages 10 to 15 . In the Adventist Church, it is a recent phenomenon that there is some interest and study done on early adolescents exclusively; however, this project will enhance the knowledge and information needed to continue to develop and build a ministry specifically designed for early adolescents. In addition, another significant aspect of this project is that it is a process-focused youth ministry rather than an event-oriented youth ministry. It emphasizes the importance of building mentoring and discipleship relationships with early adolescents. 


\section{Description of the Project Process}

A theological basis for this project will include an examination of biblical examples and teaching on mentoring and discipling of early adolescents. The writings of Ellen White will also be consulted; current literature will be reviewed, which will include books and articles on early adolescence, their spirituality, and ministry to and for them.

The early adolescents of the church will be introduced to both long-term and short-term mentoring and discipleship programs which will be developed and implemented as a part of a youth and young adult ministry program/strategy of the church. To accomplish this, four steps will be taken: (a) church will take an action to develop and implement the early adolescent mentoring and discipleship program for a seven month period; (b) in partnership with parents, a discipleship group of early adolescents will be formed; (c) early adolescent-oriented events, activities, and a long term service project will be developed and implemented; and (d) three to five hours per week of pastoral mentoring and discipleship will be provided for the discipleship group. The early adolescents will be aware that they are being mentored and the terms mentor and mentee will be used frequently during the mentoring and discipleship program/process.

These early adolescents will be asked to keep journals to record their thoughts and experiences during the process, and after being reviewed by their parents, their journals will be used in evaluating the effectiveness of the mentoring and discipleship program. They will also participate in Friday youth vesper services/meetings where they will be given a chance to describe and reflect on their experiences in participating in a mentoring and discipleship program. Parents' observations and comments may also be used in 
evaluating the program. For the evaluations, two aspects will be explored: (a) How both seven years of long-term and seven months of short-term mentoring and discipleship relationship impacted the early adolescents? (b) Did the level of involvement in service activities by early adolescents increase?

\section{Definition of Terms}

Christian Identity: The identity Christians associate to that of Jesus' life and death in all their aspects of living and being.

Discipling: The process of teaching people to become like Jesus, realizing their God-given full potential, by living Jesus' life of service and self-sacrifice. Discipling is interchangeable with the word "mentoring" as they share similar principles and definitions, especially referring to Jesus' earthly ministry. The terms mentoring and discipling will be used interchangeably throughout the project/study to refer to "a dynamic, intentional relationship of trust in which one person enables another to maximize the grace of God in their life and service" (Biehl, 1996, p. 8).

FNL: Friday Night Live youth and young adult vespers service of the KitchenerWaterloo Seventh-day Adventist Church.

FOLLOW ME: Acronym referring to a mentoring and discipleship model introduced in the project.

Mentoring: "Lifelong relationship, in which a member helps a protégé reach her or his God-given potential" (Biehl, 1996, p. 19).

Mentoring and Discipleship Program/Process: Intentional presence, care, nurture, and teaching provided by the researcher [me] during his ministry at the Kitchener- 
Waterloo Seventh-day Adventist Church emphasizing the importance of living Jesus' self-renouncing and self-sacrificing love resulting in giving selfless Christian service.

Millennials: Those who are born in or after 1982 (Howe \& Strauss, 2000) to 2000 or 2001, who are also known as "Generation Y."

Reach-Out Missionary Movement (ROMM): Youth and young adult missionary project of the Kitchener-Waterloo Seventh-day Adventist Church which began in 2007. Reach-Out \& Care Missionary Movement (ROCMM): Youth and young adult missionary project of the Kitchener-Waterloo Seventh-day Adventist Church which began in 2007 with the name of Reach-Out Missionary Movement (ROMM) and later changed to Reach-Out \& Care Missionary Movement (ROCMM).

Talmid: Hebrew word meaning pupil, student or disciple.

Talmidim: Plural of talmid. 


\section{CHAPTER 2}

\section{A THEOLOGICAL BASIS FOR EARLY ADOLESCENT MENTORING AND DISCIPLESHIP}

\section{Introduction}

The first section of this chapter will explore the lives of two adolescents in the Bible, one from the Old Testament and the other from the New Testament, in an attempt to show adolescent behaviors and characteristics from a biblical context. The second section of this chapter will examine the theological foundation for mentoring and discipleship. The third section of this chapter will list and explore the mentoring and discipleship relationships in the Bible, including examples of early adolescents' mentoring and discipleship relationships. Throughout the chapter, the importance of mentoring and discipleship principles in the Bible will be explored. Furthermore, the Scriptures and Ellen G. White's comments will be used to support the importance of early adolescent mentoring and discipleship.

\section{Early Adolescents in the Bible}

The term adolescence is an invention, a byproduct of Western culture which emerged in the beginning of the $20^{\text {th }}$ century. Balswick, King, and Reimer (2005) stated that "Adolescence, as a period of life, has only been recognized in the last century... [and] Hall (1904) was the first person to name the significance of a unique stage of 
development between childhood and adulthood" (p. 168). The term adolescence or "adolescent" does not exist in the Bible. In order to determine who early adolescents in the Bible are, one needs to know the behaviors and characteristics of early adolescence. Early adolescence will be explained in great detail in the next chapter. However, even without any additional information, it is not difficult to find early adolescents in the Bible who held major responsibilities, duties and tasks as they successfully transitioned from childhood to adulthood.

\section{A Scriptural View of Childhood and Adolescence}

Many have suggested varying opinions regarding at what age adolescence begins (Balswick et al., 2005; Dayringer, 2000; Frydenberg, 1997, 2008; Kelcourse, 2004;

McDevitt \& Ormrod, 2004; Steinberg, 1996). However, all agree that adolescence is the period between childhood and adulthood. To determine in the Bible exactly at what age adolescence begins is a challenge, since the word "adolescence" is a Western phenomenon, a cultural byproduct. Because there is no such word as "adolescence" or "adolescent" in the Bible, an understanding of the Scriptures that speak of "child," "youth," "lad," or "young man" in an exegetical context is necessary in order to correctly apply the meaning of the Scriptures. In 1 Sam 2:11, it says that Samuel "the child did minister unto the LORD before Eli the priest." According to the Seventh-day Adventist Bible Commentary, here the word translated "child" is na' ar, meaning "a boy of any age up to maturity" (Nichol, 1978, p. 2:462) and also that "at the age of 17 Joseph is called $n a^{\prime} a r$ (p. 2:462). The word na'ar is also used for Eli's sons in 1 Sam 2:17 as the word is translated as "young men." Therefore, childhood in the Bible should not be understood in the same way it is in the Western world. In 1 Sam 12:2, the word na'uwr was 
translated into "childhood" (KJV) but as "youth" (NASB \& NIV) in other Bible versions. Childhood in the biblical world has a much broader meaning and application than it does today.

Therefore, when using the words adolescence or adolescent in the biblical context, it should be understood as a period when a child begins to exhibit behaviors and characteristics that are more "adult-like" than "childlike," since the period is a transitioning one from childhood into adulthood. Steinberg (1996) stated, "Although it may seem frustrating, determining the beginning and ending of adolescence is more a matter of opinion than absolute fact" (p. 4).

\section{Samuel}

Samuel was brought to the house of the LORD when he was weaned (1 Sam 1:24). Exactly at what age Samuel was weaned is not known, but according to the Seventh-day Adventist Bible Commentary, "it is a common thing in the Orient for a child to continue nursing till he is three years old" (Nichol, 1978, p. 2:457). Hannah brought her young son to Eli and there Samuel worshipped the LORD (1 Sam 24-28) and there he ministered before the LORD (1 Sam 2:11, 18; 3:1). The age at which Samuel regularly "ministered" in the temple is not known, but Nichol estimates the earlier part of Samuel's ministry under Eli's mentorship as between the ages of 3 to 15 (Nichol, 1978, p. 2:462).

Samuel was wearing "a linen ephod" (1 Sam 2:18), "a garment used by the inferior priests and Levites, and, at times, even by eminent persons among the people" (Nichol, 1978, p. 2:463). Samuel wearing a linen ephod suggests that his duties were not menial, but rather, he was attending to sacred duties. 
Here is an example of how a child grew and became an early adolescent, holding important responsibilities at an early age, responsibilities that would have been normally reserved for those who were much older and more mature. White (1890) explains that Samuel ministering at such a young age was not customary, since the Levites entered into their "peculiar services" when they reached 25 years of age. We see here how Samuel went through social transitions, a characteristic of adolescence, and how he performed adult responsibilities.

\section{Jesus}

At the age of 12, Jesus went to the feast in Jerusalem with His parents. When the feast was over, while His parents departed from the city and were heading home, $\mathrm{He}$ stayed behind in the city for three days in the temple courts listening to the teachers and asking them questions (Luke 2:41-52). He was found by His parents among the teachers who were amazed by "his understanding and his answers" (Luke 2:47, NASB). A conversation then ensued between Him and his concerned parents in which they asked Him why He caused them to worry. Their question was met with a volleying question from Jesus, "Why is it that you were looking for Me? Did you not know that I had to be in My Father's house?" (Luke 2:49, NASB).

Here Jesus exhibits clear and typical adolescent behavior and characteristics. On this occasion, Jesus is thinking and reasoning with the teachers, exercising His abstract thinking abilities. He was sharing His ideas in this social interaction, discussing with them and challenging them, including His parents. What McDevitt and Ormrod (2004) observed in early adolescents, that the ability to think abstractly begins at this time, is 
being seen here in Jesus' behavior, indicating that He was an early adolescent when this story unfolded.

\section{Theological Foundation for Mentoring and Discipleship}

What is mentoring and what is discipleship? These two words are closely related, but the origins of these two words are from two very different backgrounds. Mentoring comes from Greek mythology and discipleship from the Greek word disciple in the New Testament.

\section{Mentoring}

Mallison (1998) describes how the word "mentoring" originated:

The word 'mentoring' comes from Greek mythology... In Homer's Odyssey, Mentor was the wise and trusted companion and friend of Ulysses and the guardian of his house during his ten-year absence at the Trojan wars. He acted as teacher and adviser of Ulysses' son Telemachus, helping him to develop sound values, attitudes and behavior so that he would mature to be an upright, wise and courageous adult. (p. 8)

Mentor was the wise and trusted companion and friend of Ulysses who was in charge of Ulysses' son, taking very good care of him, so that he would become a mature, upright, wise and courageous adult. However, presently the word "mentor" is being used to describe someone who provides special care, nurture, attention and assistance to others in order to allow them to reach their maximum potential.

\section{Definitions of Mentor and Mentoring}

Krallmann (2002) describes what a mentor is:

A mentor in the Bible sense establishes a close relationship with a protégé and on that basis through fellowship, modeling, advice, encouragement, correction, practical assistance and prayer support influences his understudy to gain a deeper comprehension of divine truth, lead a godlier life and render more effective service to God. (p. 122) . 
According to Krallman's definition of a mentor, Jesus was a mentor to His disciples. From His first command to His disciples to follow Him, to His last command to go and make disciples, Jesus was there for them, always present, available and ready to serve them and to teach the principles of the heavenly kingdom. This definition allows us to see how mentoring and discipleship are closely linked and related.

There are different definitions to best understand what mentoring is all about. Mallison (1998) defines Christian mentoring in this way: "Christian mentoring is a dynamic, intentional relationship of trust in which one person enables another to maximize the grace of God in their life and service" (p. 8). Biehl (1996) defines mentoring simply as, "Mentoring is a lifelong relationship, in which a member helps a protégé reach her or his God-given potential" (p. 19).

Mallison (1998) also borrows J. Robert Clinton's definition of mentoring of potential leaders:

Mentoring refers to the process in which a person with a serving, giving, encouraging attitude (Mentor), sees the leadership potential in a still to be developed person and is able to prompt or otherwise significantly influence that person along to the realization of his/her potential. (p. 10)

This definition also clearly describes how Jesus, as their Mentor, helped His willing disciples reach their full potential.

\section{A Biblical Definition}

In searching for a biblical definition, Mallison (1998) explained that Bishop John Reid uses Jesus' command to Peter "strengthen thy brethren" (Luke 22:32) as the basis for a biblical definition, as Peter was commissioned to do for his peers what Jesus did for him, enabling him to minister. According to Mallison (1998), Reid states that 
"Mentoring describes an intentional and deliberate attitude to encourage another's life and ministry. It finds its biblical basis in Jesus' words to Peter" (p. 10).

\section{Discipleship}

The term discipleship has been used by many for many years, but when asked, one will notice that people mean different things when they talk about discipleship. Discipleship began when Jesus bade His disciples to "Come, follow Me [Him]" (Matt 4:19; Mark 1:17). However, it is unclear to many whether "following" means to simply enter into a relationship with Jesus, learn from Him, and be content with it or to go further and fulfill Jesus' commission to "make disciples of all nations" (Matt 28:19, NASB). I would suggest that the biblical meaning of discipleship is to fulfill Jesus' command to follow Him, which includes also the commission to make disciples as Jesus did. The command to follow Jesus is a command to be like Him in everything, including giving one's own life for others as Jesus did. Beagles (2009) stated that "at a minimum, both following Christ and making other disciples are involved in the concept of discipleship" (p. 20).

What is the purpose of Christian mentoring and discipleship? I would suggest that it is to allow a new believer to meet and experience Jesus as the followers/disciples of Jesus did. Then, to empower them to introduce others to Jesus allowing them also to meet, learn and experience Jesus for a higher and more meaningful life and finally, to become like Christ. Samra (2003) concluded, "it is best to think of discipleship as the process of becoming like Christ" (p. 220).

The term disciple is often understood to be a follower or a student of a mentor, teacher, or other figure. Bonhoeffer (1963) explained, "Discipleship means adherence to 
Christ, and, because Christ is the object of that adherence, it must take the form of discipleship" (p. 63). What is discipleship? A simple definition I would provide is following Jesus to learn from Him and to become like Him.

“Come, Follow Me"- Jesus' Model of Mentoring and Discipleship When Jesus said, "Come, follow Me" (Matt 4:19; Mark 1:17) to his future disciples, what did that invitation mean? What did it mean to follow Jesus then and what does it mean to follow Him now? In this section, the theology of mentoring and discipleship will be explored as Jesus' model or ministry of mentoring and discipleship will be studied.

\section{Historical and Cultural Background}

As noted, the concept of adolescence was developed in the beginning of the twentieth century in the Western world. To apply the twentieth or twenty-first century Western cultural understanding and findings of adolescence to the first century, the time of Jesus, it would require careful exegetical study of the history and culture known then.

Torah

"In the first-century Jewish society, Torah shared center stage with Jerusalem" (Young, 2007, p. 29), and “the central passion of the people of Jesus' world was teaching, living, and obeying the Torah" (Bell, 2005, p. 123). Neudecker (1999) found that in the disciple-rabbinical relationship in Rabbinic Judaism, "Torah study is considered as a form of the worship of God... [and] it is the very purpose of one's existence... [as they believe that learning much Torah] is the purpose for which you [they] were created" (p. 250). Bell (2005) stated that "[they] believed that the Torah was the way, the truth, and 
the life... [And for them] the best way to live was to live how the Torah said to live" (p. 123). Adults were responsible to guide and nurture children in the "way of the Lord" (Jankiewicz \& Jankiewicz, 2011), and to them, the Torah was "the way."

Education was not seen as a luxury or even as an option, but as the key to survival and "The Torah was seen as so central to life that if you lost it, you lost everything" (Bell, 2005, p. 123). Bell quoted from the first century Jewish historian Josephus, "Above all else, we pride ourselves on the education of our children" pointing out that teaching, learning and applying the Torah was the very essence of Jewish people's survival and existence.

\section{Bet Sefer and Bet Talmud}

When Jewish children were around 6 years old, they attended school, Bet Sefer (which means "House of the Book") for the first time, where they learned and memorized the Torah (Genesis, Exodus, Leviticus, Numbers and Deuteronomy) from their local rabbi of the local synagogue until they were about 10 years old (Bell, 2005). As the rabbis would teach the Torah to the children, they were literally applying the teachings and instructions of the Torah (Gen 18:19; Deut 6:5; Exod 12:26-27; 13:8; Lev 23:43).

By age ten, some students "demonstrate their natural abilities with the scriptures and distance themselves from the others," and went on to the next level of education in Bet Talmud ("House of Learning"), where they learned and memorized the entire Hebrew Scriptures from Genesis to Malachi, while others, who were not as successful in their learning, went back to their homes to learn their family trade (Bell, 2005, p. 125). Bell found that in Bet Talmud, students learn the art of questions, the text, and also "massive oral tradition" which was developed by brilliant minds for thousands of years (p. 126). 
In Bet Talmud, learning was done not by simple "transmission of information" from the rabbi to the students, but rather, the students were encouraged to engage in deep thinking and understanding by dialoguing as the rabbis asked questions while the students were taught to answer by asking questions. These answers in the guise of a question were again met with still more questions. Bell (2005) explained that "In the world of rabbinic education, the focus was on questions, which demonstrated that the student not only understood the information, but could then take the subject to a step further" (p. 127). The process of asking and answering questions was a basic way of learning in ancient Judaism (Young, 2007).

Jesus who was an early adolescent at the age of 12 (by Western understanding and definition of early adolescence), was found in the temple courts, sitting among the teachers, listening to them and asking them questions while everyone who heard Him was amazed at His understanding and His answers (Luke 2:46-47). Jesus exhibited how other Jewish boys would probably engage in further learning of the Scriptures. As a Jewish boy, Jesus was well versed in the Scriptures "because from an early age Jewish people were taking in the words, and they were becoming a part of them" (Bell, 2005, p. 124).

\section{Bet Midrash}

When students come to the end of Bet Talmud at around the age of 14 or 15, "only the best of the best of the best were still studying" as most students by now were also "learning the family business and starting families of their own" (Bell, 2005, p. 127). Tradition would suggest that early adolescent girls got married at 13 years old, "the age Jewish maidens of that time married" (Chilton, 2000, p. 6). Those remaining would seek a well-known rabbi and apply to become that rabbi's talmidim (disciples), and when 
accepted, they would enter the next level of education Bet Midrash ("House of Study") (Bell, 2005, p. 128). When a student presented himself to a well-known rabbi and said, "Rabbi, I want to become one of your disciples," he would be questioned "about Torah, about tradition, about other rabbis... about the prophets and the sages and the oral law...about interpretation and legislation...about words and phrases and passages" (Bell, 2005, p. 128). Bell explained that when a student is questioned and tested by a rabbi to see if worthy of further education, only then the rabbi would say, "Come, follow me" and the student would become one of the rabbi's talmidim. For those who did not pass the test, they would be told to go home and continue learning the family business. Being a disciple of a rabbi was far more than just being a student. "The goal of a disciple wasn't just to know what the rabbi knew, but to be just like the rabbi" (Bell, 2005, p. 127).

\section{Rabbi Jesus-Jesus the Teacher}

Christians are generally unaccustomed to calling Jesus "Rabbi Jesus," but there is a "wide scholarly agreement that 'rabbi' is one of the most adequate ways of designating Jesus' historical role" (Phipps, 1993, p. 57). Phipps observed that in Mark, the earliest Gospel, people addressed "Jesus as rabbi (literally, "my teacher") and $r a b b i$ is used twice in Matthew (Matt 26:25, 49) and eight times in John (John 1:38, 49; 3:2; 4:31; 6:25; 9:2; 11:8; 20:16) (p. 57). Phipps also stated that "Christians frequently overlook the fact that Jesus was most commonly known as a teacher and so emphasize other titles" such as Savior or Redeemer when "Jesus is never directly addressed as 'Savior' in the Gospels" or Redeemer in the New Testament (p. 59).

Culturally in the time of Jesus, the Torah was everything and as Jewish people, the Torah was the central purpose of their existence. They learned and lived Torah and 
the invitation, "Come follow me," is an invitation to prospective students who would go through the process of apprenticeship by a rabbi in order for them to become rabbis themselves one day. The invitation by a rabbi to come follow is an invitation for them to engage in a deeper learning of the Torah, learning to practice and apply the teachings of the Torah which would be given by rabbis, and also to imitate and duplicate the life of the rabbi. According to master-disciple relationship in Rabbinic Judaism when talmidim were asked to follow a rabbi, they were expected to sacrifice everything, pledging their loyalty and allegiance first to their rabbi, then to their parents, to engage in a life of learning and living Torah in order to be able to teach others Torah as rabbis one day. However Jesus' invitation was more than just to learn the information of the Torah or the Talmud, but it was also to properly apply the teachings of the Torah. Jesus said, "Do not think that I came to abolish the Law or the Prophets; I did not come to abolish but to fulfill" (Matt 5:17, NASB).

When Jesus invited to "come, follow Me [Him]" and apprentice with Him, Jesus intended to teach them the true meaning of the Torah. That it was not a self-righteous experience or a legalistic experience, but the experience of fulfilling the self-sacrificing love of God which is the principle of life in the universe. White (1898) states,

It will be seen that the glory shining in the face of Jesus is the glory of self-sacrificing love. In the light from Calvary it will be seen that the law of self-renouncing love is the law of life for earth and heaven; that the love which "seeketh not her own" has its source in the heart of God; and that in the meek and lowly One is manifested the character of Him who dwelleth in the light which no man can approach unto. (p. 19)

Jesus, who was well-versed in the entire Hebrew Scriptures (or Old Testament), wanted to teach His disciples what the law, or Torah meant, and by His personal example of properly applying the principle of Torah, He wanted to teach the disciples the value of caring for others and loving others as Jesus did. The Hebrew nation was appointed to 
communicate this to the world, however, due to a pursuit for self-righteousness and elitism, they failed to recognize their God-given mission. Krallmann (2002) stated, "For a talmid ["disciple" or "student"], his rabbi was not merely an intellectual and theological authority, he served as a living example, too" and "To facilitate this process of imitation a disciple entered into a life-sharing companionship with his rabbi” (p. 33). By living the life of self-renouncing and self-sacrificing love, Jesus taught His talmidim what is the true spirit and message of the Torah and the Talmud, the true identity of the nation: that it is not legalism or self-righteousness, but to transmit God's forgiveness and grace for the redemption of the entire human race.

\section{Adolescent Identity}

As adolescents struggle with their identity, often finding themselves in an identity crisis, Jesus came to provide a true and complete picture of their true God-given identity. The mentoring and discipleship in a biblical sense is to instill in the minds of mentees (sometimes called mentorees) or students or talmidim that their true identity is to live a self-renouncing, self-sacrificing love for God and others (Matt 22:37-40). "Come, follow Me," a profound theological experience of one learning from God Himself, is an invitation for Jesus' disciples to learn His divine identity, the image of God, created at Creation, to restore that broken image of God in His disciples and for them to mimic Jesus' life and do as He did. White talks about Christian education as restoration of the broken image of God, "The true object of education is to restore the image of God in the soul" (White, 1890, p. 595).

Rabbis were served and cared for by their talmidim. However, Jesus in contrast served His own students by washing their feet. This is the evidence that the entire Jewish 
nation was under an identity crisis and Jesus, the Word Himself, came to deal with the moratorium and to establish and instill true Messianic understanding or Christian identity. The purpose of mentoring and discipleship is to introduce this Christ-like identity of selfrenouncing and self-sacrificing love, a life of service, to be taught as the true identity that we Christians, like adolescents, need to master.

It is the duty of those who are in the position of mentoring and discipleship to be like Christ in introducing this identity in order that the students will master Christ's identity of self-sacrificing love of God. The disciples mastered the teachings of Jesus and became true followers of Christ. While earthly rabbis were more interested in their own reputation and their own recognition, often taking advantage of those who gave gifts and offerings to support the rabbis who were esteemed the highest in Judaic society, Rabbi Jesus showed the opposite lifestyle of giving and serving. While the rabbis disseminated information and impressed upon the people the importance of adhering to the law and all the legalistic requirements, Jesus came to teach the essence of the law and practiced service. While the rabbis, talmidim and all the Jewish people considered the Torah to be the way, the truth and the life, Jesus reminded that He is the way, the truth and the life and reminded that Torah is not about them, but Torah is about God and doing His will. The mentoring and discipling of Jesus was more than an intellectual experience. It was a holistic experience, the nature of Christ, penetrating and incarnating the lives of adolescents and young adults as they lived to die for Christ and others.

In His Beatitudes (Matt 5), Jesus challenged the pride and the ostentatious and boisterous spirit of the Jewish nation and He instilled a new, divine and meaningful identity in the disciples. Their changed lives were filled with determination, a clear sense 
of purpose and direction, which changed the world, and as they became a service to others, they ultimately served with their own life. Jesus did all this by being present, being compassionate, being loving; caring, being an educator, a teacher, a master, and a father. His invitation to the children to come to Him was His announcement to the world that He values the simplicity and innocence of children and that the ministry should begin from very young children, being present and assisting them in the process of their simplicity and innocence, being filled with divine character and attributes of their Heavenly Father.

\section{The Biblical Mentor and Discipler}

We do not know what Jesus' life was before He started his rabbinical life as a teacher foremost, and later as a Savior, but from information from Ellen G. White, we are told that as a young child, He influenced and mentored others, including his peers, as $\mathrm{He}$ found favor both in the eyes of others and God. The true theology of mentoring and discipleship is for mentors or disciplers to first become true followers of Christ, emulating the life of Jesus Christ as best as they can live, so that through their Christ-like examples and Christ-like living, they would naturally attract mentees as Jesus attracted children through His gentle, kind, patient, and caring demeanor, while inviting them to become His followers or His disciples. The theology of mentoring and discipleship is, by the initiation, interaction, incarnation and transformational workings of the mentor's influence to ensure, that a student or mentee (sometimes called a mentoree) would learn from the mentor, how to live that same life. This occurs from the step-by-step instructions they received through a hands-on apprenticeship experience. 
The story of Elisha and the Shunammite's son (2 Kgs 4:8-37) illustrates this, as Elisha had a continual influence on the boy through a regular presence at the home. $\mathrm{He}$ was able to mentor the boy by repeatedly, showing his care and concern for him during his visits with him. This mentoring was enough to maintain the relationship, however, when the boy died, a more drastic approach was needed. Elisha had to become one with the dead child, breathing as it were, into him the breath of life through the influence of the Holy Spirit. As he envelops the dead child, the warmth and life of the mentor is transmitted through to the mentee by divine intervention, divine interaction and divine impression, and the boy lives. By the help of the Holy Spirit, mentees will go through the process of life -- of truly becoming one with Jesus -- as they observe the examples of Christ's under shepherds, and Christ's disciples. The Bible shows all aspects of Jesus' mentoring relationship with His disciples --- He forgave them, befriended them, fellowshipped with them, He opened Himself up to them, while encouraging them to be open to Him.

Jesus reminded the disciples of the importance of replicating His life that is, living everything that the rabbi is living. He does not stand in their way or obstruct them, but empowers them and sends them out freely with trust and faith in them. Empowering them to go and give everything they have, including their lives, so that the people in the world, one by one, will learn of the life Jesus lived. As the world is evangelized, the true identity of God will be known, learned and lived. This is the mentoring and discipleship of Jesus Christ. To allow people to become like Jesus will change their lives, will change the lives of their friends, their fellow Christians and their church, and by its influence, the world will be changed. This is the grand ministry of Jesus. The true theology of 
mentoring and discipleship, the true theology of Jesus' command to "Come, follow Me [Him]," become like Him and do what He did, is to love and serve others and make disciples for Him.

\section{Jesus the Mentor and the Discipler of Adolescents}

Jesus' role as mentor and discipler is exemplified in the relationship he had with the disciples. However, even as powerful as His mentorship was, it was made even more significant by the concept that the disciples may have been younger rather than older. In fact, there is evidence to suggest that the disciples may very well have been adolescents under the mentorship of Jesus. There are a few points that suggest this idea. First, as stated in Exodus 30:14-15, the Jewish law stated that every male over the age of 20 was to pay half a shekel as temple tax. In Matthew 17:24-27, as Jesus and the disciples were coming to Capernaum, Jesus instructed Peter to find their portion of the tax inside the mouth of the fish. It was only enough money to pay tax for Jesus and Peter, not the other disciples who were with them. Thus, it is possible that they may not have needed to pay the tax because they were not over 20, or Peter would have found more than one shekel in the mouth of the fish. Secondly, in John 13:33, Jesus calls his disciples "little children," a phrase He would probably not use with grown, mature men, but would more likely use as a rabbi to his adolescent talmidim, when addressing them. Also, the only disciple mentioned in the Bible who was married was Peter, who again seemed like the eldest among the disciples since Jewish men usually married after the age of 18 .

Next, according to the Jewish education system, children would study the Torah and memorize the Old Testament by the age of 15 . If a rabbi decided that the student did 
not demonstrate they were good enough to continue studying, their education would end, and the students would consequently return to their families and begin working in the family trade (Bell, 2005). As we read the stories of Jesus calling His disciples, we find that they were already working in their trade, implying they had finished their education and were rejected for any other formal rabbinical training. Thus, when Rabbi Jesus handpicked them to be His talmidim, they were eager to accept and leave behind their work to become His disciples, since they had already been rejected by the other rabbis. Therefore, it was more likely the disciples were in their adolescence. In addition, the behavior of the disciples is characteristic of the behavior of adolescents. Their overzealous nature, foolishness, and immaturity were typical of adolescence. It was more probable that fear stricken teens woke Jesus up in the middle of a storm for help (Matt 8:23-27; Mark 4:35-41; Luke 8:22-25) and not work-hardened, experienced fisher men. A mother of young teenage boys asking Jesus which of her sons would sit at His right hand is more likely than a mother of older, mature men, and a group of teenagers arguing who would be the greatest in Jesus' kingdom rather than a group of older, adult men.

Jesus' example as a mentor to the disciples exemplifies what a mentor should be, showing how the identity of God lived in us causes us to love and serve others, making them disciples for Christ: However, the fact that it was probably adolescents that Jesus mentored in this powerful and tremendous way, placing the responsibility of learning the character of God and living it on them, makes it so much more significant. Instead of calling older men to mentor and follow Him, commanding them to go and make disciples for His kingdom, to continue the great and mighty work of the Lord, it was young, inexperienced, awkward, immature adolescents whom He called to carry on this 
immensely powerful and important work. Jesus knew the tremendous effects of mentoring adolescents, helping them find their identity in God, making them disciples for His kingdom, empowering them to become so much like Him, that He would commission them to go and make disciples themselves. After Jesus' ascension to heaven, it was a small group of adolescents who, after being mentored so effectually, changed the world, and who eventually became martyrs for the work of the Lord. How powerful a thought, that Jesus chose adolescents to do His work in bringing the character of God to the world when the Jewish nation failed, that if adolescents can be effectively mentored as Jesus did, the overwhelming impact they can have in the work of God. It is inspiring and moving to know that 11 young people changed the world of their day and ten became martyrs for God's work, -- eleven young people who experienced the Pentecost and who were the actual hands of God working in the world. How powerful the thought that this sort of revival and reformation, this sort of spiritual awakening could be brought back into the Laodicean church by none other than effectively mentored adolescents.

\section{Come, Follow Me--Jesus' Mentoring and Discipleship}

In Jesus' invitation "Come, follow Me," there exist many principles of what many understand individually as mentoring and discipleship. Following Jesus' experience encompasses and exceeds many different ideas of mentoring and discipleship. Jesus said, "Follow My teachings and learn from Me" (Matt 11:29, NLT). Characteristics of Christ's mentoring and discipleship include a wide range of elements and intentionality. Jesus' ministry, His mentoring and discipleship, was filled with stories of forgiveness, friendship, fellowship, openness, honesty, sharing, unconditional self-sacrificing love (agapao), lowliness and humility, personal care and acceptance, loyalty, long-suffering 
and patient, expectation for obedience, worship and witnessing, modeling, mentoring and discipling others, service and self-sacrifice, evangelism and more. These are the key attributes of Jesus' mentoring and discipleship.

\section{Summary}

To summarize how Jesus mentored and discipled His followers, White (1911) shares the following:

For three years and a half the disciples were under the instruction of the greatest Teacher the world has ever known. By personal contact and association, Christ trained them for His service. Day by day they walked and talked with Him, hearing His words of cheer to the weary and heavy-laden, and seeing the manifestation of His power in behalf of the sick and the afflicted. Sometimes He taught them, sitting among them on the mountainside; sometimes beside the sea or walking by the way, He revealed the mysteries of the kingdom of God. Wherever hearts were open to receive the divine message, He unfolded the truths of the way of salvation. He did not command the disciples to do this or that, but said, "Follow Me." On His journeys through country and cities, He took them with Him, that they might see how He taught the people. They traveled with Him from place to place. They shared His frugal fare, and like Him were sometimes hungry and often weary. On the crowded streets, by the lakeside, in the lonely desert, they were with Him. They saw Him in every phase of life. (pp. 17-18)

Jesus' earthly ministry should serve as a model for mentoring and discipleship.

The FOLLOW ME model of mentoring and discipleship that will be introduced in the later chapter is especially valuable for early adolescents, given the nature of their characteristics and tendencies. Since early adolescence is a period of major changes in young people's lives, then Jesus' ministry and the FOLLOW ME mentoring and discipleship model should be a profoundly affective and effective experience in their lives. Mentoring and discipleship share common principles and practices and they can be used inclusively in implementing Jesus' ministry model and the FOLLOW ME Mentoring and Discipleship Model which will be introduced and elaborated on further in chapter six. 


\section{Biblical Examples for Mentoring/Discipleship}

There are many examples of mentoring/discipleship in the Scriptures, some more well-known than others. In this section, the better known ones will be used both from the Old Testament and the New Testament.

\section{Old Testament Examples of Mentoring/Discipleship}

Many studied the Scriptures and found the following examples as the biblical examples for mentoring and discipleship (Mallison, 1998). All the examples listed below are being used by more than one author as examples for mentoring and discipleship. I have listed a number of the examples found as the examples for mentoring and discipleship.

\section{Jethro and Moses}

In Exodus 18, we can see how Jethro, Moses' father-in-law mentored Moses. After 40 years of tending Jethro's sheep, Moses had a special relationship with his fatherin-law which allowed Moses to receive counsel from him when he visited. Jethro taught and instructed Moses how to delegate responsibilities (Exod 18:17-23). The Bible says that "So Moses listened to his father-in-law and did all that he had said" (Exod 18:24, NASB). A great leader such as Moses who had a royal upbringing and education also needed a mentor to lead and guide him when he was faced with many challenges due to his taxing leadership role. Moses was mentored by Jethro before he got burned out.

\section{Moses, Joshua and Caleb}

In Deut 31, Moses repeatedly encouraged Joshua to be strong and courageous. Moses summoned Joshua and gave him instructions and revealed to him God's plans for 
him (Deut 31:7). Then, he assured and comforted him by saying that the LORD will never leave him or forsake him (Deut 31:8). The Israelites listened to Joshua because Moses laid his hands on him and he was "filled with the spirit of wisdom" (Deut 34:9, NIV). Moses brought him up mentoring and discipling him. People respected Joshua because of Moses, his mentor, and also what he had become under Moses' mentorship. Not only did Moses have a great influence on Joshua, but also on Caleb. Caleb became a godly leader of Israel and later when he was 85 years old, he shares with Joshua his special experiences and bond he had with Moses (Josh 14:6-15).

\section{Elijah and Elisha}

Elijah called Elisha to become his apprentice to carry on his ministry, simply by putting his cloak around him, and Elisha followed Elijah and became his "assistant" (1 Kings 19:19-21, NLT). When Elisha was called, he requested of Elijah that he be allowed to go back "to kiss my [his] father and mother good-by" (1 Kings 19:20, NIV) and returned abandoning his former trade in order to follow Elijah as his apprentice. He burned the "plowing equipment" (1 Kings 19:21, NIV), a symbolic gesture showing that he is not coming back to his old trade, but starting a new life fully dependent on his teacher. The bond between the two was very strong and Elisha told Elijah three times that as long as the LORD lives and Elijah lives, he will not leave him (2 Kings 1:2, 4, 6). Elijah discipled Elisha until the last day of his life here on earth and there existed a deep connection between the two as a mentor (teacher) and a mentee (student). 


\section{New Testament Examples of Mentoring/Discipleship}

\section{Barnabas and Paul}

The meaning of the name Barnabas is "son of encouragement" (Acts 4:36, NASB) and indeed he was an encouraging mentor of Paul. The Bible tells us that "he was a good man, and full of the Holy Spirit and of faith" (Acts 11:24, NASB). When Paul tried to join the disciples, they were afraid of him, but Barnabas took him in and brought him to the apostles and gave a good report of him resulting him to be able to stay with them and participate in their ministry (Acts 9:26-28).

In referring to the mentoring that Paul received from Barnabas, Mallison (1998)

stated,

The Christian church owes so much to him for his mentoirng of Paul. He recognized the potential in Paul when other believers distanced themselves from him after his conversion (Acts 9:27). He stood by Paul when he most needed a faithful friend (Acts 13:50) and celebrated with him when the church endorsed his ministry (Acts 13:2). (p. 41)

Since then, they worked together and faced challenges together until they had to part. However, Barnabas was still an encouraging mentor. Barnabas mentored John (Mark), who was the cause of the dispute between him (Barnabas) and Paul and took him to Cyprus (Acts 15:39). Mallison (1998) pointed out that "Barnabas stood by John Mark when he faltered, confronting Paul when he felt he was out of God's will in his handling of John Mark" and he "worked with him enabling John Mark to eventually become a great support to Paul, and the one who many believe was the primary author of the gospel of Mark (Acts 15:36-39; 2 Tim 4:11)" (p. 41). 


\section{Priscilla, Aquila and Apollos}

Priscilla was one of the most notable fellow workers of Paul, perhaps more distinguished than her husband Aquila. Both of them mentored and discipled Apollos explaining and teaching him "the way of God more accurately" (Acts 18:24-26, NASB). It was more than parenting as they taught Apollos how to preach about Jesus more accurately as they encouraged and supported Apollos. Priscilla and Aquila, using their knowledge of the Scriptures and their "wise and patient counsel," guided and helped Apollos in his "preaching methods and content, because of his weakness in these areas" attributing to Apollos' success as "a mighty spokesperson for the gospel" who "was called an apostle" (Mallison, 1998, p. 42).

\section{Paul, Timothy and Titus}

Paul calls Timothy "my beloved and faithful child in the Lord" (1 Cor 4:17), "my true child in the faith" (1 Tim 1:2, NASB) and "my beloved son" (2 Tim 1:2, NASB). Timothy was converted when he was very young and the two often worked closely together (Acts 18:5; 19:22; 2 Cor 1:1; Phil 1:1; Col 1:1; 1 Thess $1: 1,2 ; 2$ Thess $1: 1$ ). There is further evidence of Timothy's service with Paul (1 Cor 4:17; 16:10-11), where Paul calls him "my fellow worker" (Rom 16:21, NASB). As Timothy's mentor, Paul gave counsel to Timothy and also affirmed him (2 Tim 3:10-15). Paul also had a special relationship with Titus. He calls Titus "my true child in a common faith" (Titus 1:4, NASB) and supported and commanded him (2 Cor 12:14-18). Paul invited Titus to his ministry and also sent him to difficult assignments (Gal 2:1-5; Titus 3:12; 2 Tim 4:10). 


\section{Jesus, the Disciples and Mary Magdalene}

Throughout the Gospel books, Jesus mentored and discipled His followers to become "fishers of men" (Matt 4:19, NIV) and when they devoted to the teaching and to the fellowship, to the breaking of bread and to prayer, many people were saved through the ministries of the followers of Jesus (Acts 2:42-47). Indeed they became fishers of men. One of the followers of Jesus was Mary Magdalene, who followed Jesus along with His twelve disciples (Luke 8:1-3). Since the time Jesus drove out seven demons from her, she followed Jesus and had the privilege to announce first that Jesus had risen (Matt 28:1-8; Mark 16:1-11). Her love for Jesus shows how much she appreciated His company and His mentoring and discipleship.

\section{Peer Mentoring}

In the Bible there is also evidence of peer mentoring, such as how people of similar backgrounds influenced one another, both positively and negatively. Mallison (1998) described peer mentoring which he also refers to as "co-mentoring," as an equal relationship where both parties are giving and receiving. This kind of peer influencing is also called peer pressure and we can see how negative peer pressure can cause destruction in the story of the jeering youths (2 Kings 2:23-25).

\section{David and Jonathan}

Jonathan, as son of the king, would have become king if it had not been for David. Yet, they had such a deep friendship and camaraderie, love, respect, and care for one another. Jonathan loved David, as he loved himself, and gave him his robe and his sword (1 Sam 18:1-4) willing to pledge his loyalty to David more so than to his own 
father, King Saul. Jonathan protected David from his father Saul who was trying to kill him (1 Sam 19:1-7; 20:1-42). There existed between David and Jonathan a deep friendship and loyalty to each other. Their peer mentoring or co-mentoring was evident in the Scriptures as they developed a very special self-renouncing relationship, positively influencing each other.

\section{Biblical Examples of Early Adolescent Mentoring and Discipleship}

Jochebed and Moses

Moses was under the care of his mother Jochebed until he was about 12 years old (Nichol, 1978, p. 1:503). Throughout his childhood and into adolescence, his mother intentionally mentored, discipled, and instilled in him his true identity.

White (1988) shows how Jochebed mentored and discipled her son when she states,

Knowing that her child must soon pass beyond her care, to the guardianship of those who knew not God, she the more earnestly endeavored to link his soul with heaven. She sought to implant in his heart love and loyalty to God. And faithfully was the work accomplished. (p. 353).

Jochebed was a mother who understood her responsibilities and she purposefully, diligently, and successfully groomed her child to honor and respect God while preparing for his God given task of delivering the Israelites from slavery.

\section{Jacob and Joseph}

The Scriptures show how much Jacob (Israel) loved his son Joseph and how much Joseph loved his father in return (Gen 37:3, 34, 35; 46:28-30).

White (1954) gives an insightful account of what Jacob did for his son Joseph, 
The lessons given Joseph in his youth by Jacob in expressing his firm trust in God and relating to him again and again the precious evidences of His loving-kindness and unceasing care were the very lessons he needed in his exile among an idolatrous people. In the testing time he put these lessons to a practical use. When under the severest trial, he looked to his heavenly Father, whom he had learned to trust. Had the precepts and example of the father of Joseph been of an opposite character, the pen of inspiration would never have traced upon the pages of sacred history the story of integrity and virtue that shines forth in the character of Joseph. The early impressions made upon his mind garrisoned his heart in the hour of fierce temptation and led him to exclaim, "How can I do this great wickedness, and sin against God?" (p. 197)

It is undeniable that Jacob's early mentoring and discipleship prepared Joseph to be able to endure all the trials he was to face when he was sold as a slave at the age of 17 .

\section{Samuel and Eli}

Samuel was brought to Eli when he was weaned at a young age (1 Sam 1:24) perhaps between the ages of three and five. However, so much was done during his first few years before he was brought to Eli. White (1954) describes, "During the first three years of the life of Samuel the prophet, his mother carefully taught him to distinguish between good and evil. By every familiar object surrounding him she sought to lead his thoughts up to the Creator" (p. 197). She (White, 1954) further describes that to fulfill her vow to God, "with great self-denial she placed him under the care of Eli the high priest, to be trained for service in the house of God" (p. 197). White (1954) states that "His early training led him to maintain his Christian integrity" (p. 197).

After leaving his mother, Samuel was placed under the care, mentoring and discipleship of Eli; and the old priest extended his warm affection towards him. White (1893) describes the special relationship that existed between Eli and Samuel, "no father even loved his child more tenderly than did Eli this youth (Samuel)" (p. 216). Eli treated Samuel like his own son (1 Sam 3:16). 
Samuel trusted Eli and was always ready to attend to Eli, be instructed by him and also render his affectionate care and services to the priest. Each time God called Samuel, he went to Eli and said, "Here I am, you called me" (1 Sam 3:5, 6, 8). This shows the close mentoring and discipleship relationship and "warm friendship" (White, 1990, p. 50) that existed between an early adolescent Samuel and the high priest Eli.

Elijah and the Widow's son

To a desperate widow who was thinking of dying with her son due to her helpless condition (1 Kings 17:12), Jesus sent Elijah (1 Kings 17:9) to bring assistance to her and her son. To a fatherless child, to have a man of God as a surrogate father would have been very encouraging. When the son died, Elijah took the dead child and laid him on his bed and stretched himself out on the boy three times and pleaded with God for the boy's life to be returned to him (1 Kings 17:19-21). An intimate and personal relationship would have been developed between Elijah and the widow's son. Elijah could have become the father figure that the widow's son was lacking and seeking.

\section{Elisha and the Shunammite's son}

There is another mentoring/discipleship relationship that developed between Elisha and the Shunammite's son. The family made a small room in their home for Elisha so that he could always rest there as he travelled the country. In his gratitude, Elisha pronounced a blessing on her so that she would have a son. Unfortunately, later the Shunammite's son died and the Shunammite woman went to Elisha at once for his assistance (2 Kings 4:18-27) asking him in her bitterness, “Didn't I tell you, Don't raise my hopes?" (2 Kings 4:28, NIV). Elisha's intervention was swift, sincere, and personal 
as he sent his servant Gehazi with his staff and with specific instructions (2 Kings 4:29). However, his first attempt at resuscitation didn't work and that pushed Elisha into using another intervention method. He got up on the bed and laid upon the body, "mouth to mouth, eyes to eyes, hands to hands" twice and revived the boy (2 Kings 4:32-35).

The story of Elijah reviving the widow's son and the story of Elisha reviving the Shunammite's son are almost identical. Both mentors showed great interest in the welfare of their young charges, who were most likely adolescents. Elisha was mentored by Elijah and when he (Elisha) was in a similar situation as his teacher was once in, he did what his teacher had done. Both leaders intervened, and had life saving and life altering relationships with their mentees.

\section{Lois and Eunice with Timothy}

Paul affirmed what Lois, Timothy's grandmother, and Eunice, Timothy's mother did for Timothy when he was young (2 Tim 1:5). He gave credit for Timothy's sincere faith to the work of his grandmother and mother. Paul was very impressed with this young man, and seeing his strong faith, requested that he join him in his missionary work. White (1970) states that "Timothy learned from the lips of his grandmother Lois, and his mother Eunice, the truths of Holy Writ" (p. 345).

\section{Jesus and Children}

Jesus said, "Anyone who welcomes a little child like this on my behalf welcomes me" (Mark 9:37, NLT). He also said, "unless you are converted and become like children, you shall not enter the kingdom of heaven" (Matt 18:3, NASB). From these two statements, one can clearly see that not only did Jesus show his affection for 
children, He appreciated them. Jesus saw something very special in them and He wanted His disciples to see the value in caring and learning from children. When the disciples did not learn what Jesus was trying to teach them and saw them rebuking those who were bringing children to Jesus, Jesus was greatly offended and commanded them to leave the children alone and let the children come to Him (Matt 19:13, 14). He then placed His hands on them and blessed them (Matt 19:15). Jesus showed His deep love, care, and concern for children as He taught the lesson that "the simplicity, the self-forgetfulness, and the confiding love of a little child are the attributes that Heaven values" and "these are the characteristics of real greatness" (White, 1898, p. 437).

White (1898) describes how Jesus gently and carefully treated the children, "Calling a little child to Him, Jesus set him in the midst of them; then tenderly folding the little one in His arms" (p. 437). Here, Jesus the Master Teacher, Mentor and Discipler, mentored and discipled the children (Matt 19:13-15). What an experience it would have been for the children to be held in the arms of Jesus as He affirmed them in front of all the disciples and their parents.

\section{Conclusion}

Why is it so important that we understand the theology of mentoring and discipleship to children and early adolescents? It is because Jesus expects us to take care of our young people just as He took care of them. Jesus values their innocence, purity, simplicity and sincerity and He wants us to take care of them, mentoring and discipling them so that they may grow to become godly men and women, prepared for the kingdom of Heaven. Jesus reminded Peter repeatedly that he "Tend My [His] lambs" (John 21:15, NASB), "Shepherd My [His] sheep" (John 21:16, NASB), and "Tend My [His] sheep" 
(John 21:17, NASB) repeatedly stating the importance of mentoring and discipling others as Jesus commanded. In spite of Peter's denials and betrayal, Jesus' first invitation and command to His disciples to "Follow Me [Him] (Come here after Me)" (Matt 4:19, NASB) to be sent out "to fish for people" (Matt 4:19, NIV) never changed, showing clearly that Jesus called His disciples to learn from the Master Teacher how to practice self-renouncing and self-sacrificing love, caring, nurturing, mentoring and discipling others for His sake. Jesus taught His disciples to mentor and disciple others, and these behaviors are what define Jesus' ministry here on earth. 


\section{CHAPTER 3}

\section{LITERATURE REVIEW ON EARLY ADOLESCENT \\ MENTORING AND DISCIPLESHIP}

\section{Introduction}

Early adolescence is a time of many changes, a challenging time, a period of stress and turmoil for many young people (Brinthaupt \& Lipka, 2002; Parrott, 2000). It is "a potentially stressful period of life," when adolescents explore different identities and "search for self," as they experience "a large variety of life changes" that "involves more acute problems and daily difficulties" (Brinthaupt \& Lipka, 2002, p. 29). However, Brinthaupt and Lipka (2002) also stated that early adolescence is "a time of maximal opportunity" when youths between the ages 10 to 15 years can also be positively influenced (p. 30). Early adolescence, which is feared by both parents and their children, should not be understood merely as a time of struggle and difficulties for everyone involved, but as a time of opportunities and possibilities for them to accomplish together something amazing and great. In this chapter, I will explore early adolescence, its characteristics and tendencies, and show how mentoring and discipleship is crucial for the growth of early adolescents in all aspects of their lives. The importance of mentoring and discipleship will also be examined in this chapter. 


\section{Early Adolescence}

Early adolescence is the starting point of adolescence and it is quite distinguishable from middle and late adolescence (Steinberg, 1996). There have been many different views on what age early adolescence actually begins, but there is no dispute that early adolescence is the beginning of one's growth process into becoming an adult, marking the start of adolescence.

\section{Adolescence}

Between the end of childhood and the beginning of adulthood or "womanhood" or "manhood" is that "ambiguous time of life we have come to refer to as adolescence" (Kaplan, 1984, p. 27). Lerner (2002) stated, "Adolescence may be described as a phase of life beginning in biology and ending in society" underscoring the idea that, "whereas pubertal changes may be the most visible and universal features of this period, the social and cultural context within which youth develop textures this phase of life" (p. 5). Much of adolescence is about "a child becoming his or her own unique person" (Balswick et al., 2005, p. 178), becoming more independent, autonomous, different and distinct.

The concept of adolescence was developed by G. Stanley Hall, "the father of adolescent psychology" (Dacey \& Travers, 2004, p. 277), when he published the twovolume book on Adolescence when he was 60 years old (Capps, 2008). The term adolescence comes from the Latin verb adolescere, which means "to grow up" or "to grow to maturity" or "to grow into adulthood" or "still growing", referring to the transitional period between childhood and adulthood (Dusek, 1991; Gumbiner, 2003; Steinberg, 1996). However, adolescence is a byproduct of a culture, a Western phenomenon, a social construction which does not exist in other cultures or in other 
countries outside the West (Hine, 1999; Kelcourse, 2004). . The existence of adolescence as a period of development is an invention of society (Fasick, 1994).

\section{Early Adolescent Years}

It was stated earlier that when using the words "adolescence" or "adolescent" in the biblical context, it should be understood as a period when a child begins to exhibit behaviors and characteristics that are more "adult-like" than "childlike." Early adolescent years are when those changes are most visible. However, to anticipate exactly at what age adult-like behaviors and characteristics will show in preadolescents is impossible as culture and society play a major role in children's individual growth.

\section{When Does Early Adolescence Begin?}

Dayringer (2000) stated that in the early 1900s, the term adolescence referred to "the age span of 13 to $20 "$ " p. 91), marking the beginning of early adolescence at the age of 13 . Since then, there have been many different views on what age early adolescence actually begins. Some say that early adolescence begins at the age of 12 (Feldmeier, 2007; Gumbiner, 2003; Kelcourse, 2004) or at the age of 12 for boys and 11 for girls (Dacey \& Travers, 2004). Others say that early adolescence begins at the age of 11 (Capps, 2008; Steinberg, 1996) while still others say it begins at 10 (Berger, 1988; Brinthaupt \& Lipka, 2002; McDevitt \& Ormrod, 2004). Balswick et al. (2005) stated, "Consequently, adolescence in the Western world is now recognized as beginning between the ages of 9 and 10" (p. 168). In Australia, according to the Department of Education and Training (Government of Western Australia), early adolescence begins as 
early as 8 years old making it much more difficult to pinpoint exactly at what age early adolescence really begins.

This change is due to children starting their puberty much earlier in the twentieth century than 100 years ago due to complex social and biological changes and factors (Balswick et al., 2005; Dusek, 1991; Mortimer \& Larson, 2002). Dusek (1991) suggested that age does not define adolescence and stated that adolescence should be defined as "a stage beginning with the onset of puberty" (p. 6). Guest (2009) agreed that "Adolescence is a distinctive stage in the lifespan because it is marked by a clear biological change: puberty" (p. 205). Puberty is one of the "transition-linked turning points" (Graber, Brooks-Gunn, \& Petersen, 1996) that marks the beginning of early adolescence. Even though puberty is one of the "transition-linked turning points" and often used as the beginning of early adolescence, and since adolescence is "the period as being composed of a series of passages—biological, psychological, social, and economic-from immaturity into maturity" (Steinberg, 1996, p. 6), the beginning of early adolescence should not be determined solely by the start of puberty. Identifying the age or event at which early adolescence begins or ends is not a simple matter given that it all depends on the boundaries one uses to define the period (Dacey \& Travers, 2004; Steinberg, 1996). Since society groups young people in educational institutions (Steinberg, 1996) and the U. S. Department of Education uses the age of 10 as the beginning of early adolescence, for the sake of the project and this paper, I will use the age of 10 as the beginning of early adolescence. 


\section{When Does Early Adolescence End?}

Some have stated that early adolescence ends at the age of 15 (Brinthaupt \& Lipka, 2002; Kelcourse, 2004) while others have claimed it ends at 14 (Capps, 2008; McDevitt \& Ormrod, 2004; Steinberg, 1985, 1996). According to Feldmeier (2007, p. 109), some even suggested that early adolescence ends at 18 , to be followed by late adolescence which ends at 23. As stated earlier, determining the beginning and ending of early adolescence is more of a matter of one's opinion than absolute fact as "adolescence has undergone a social, evolutionary transition throughout recorded history" (Dusek, 1991, p. 6) and has evolved in the Western world and culture over a century. For the sake of the project and this paper, I will use the age of 15 as the ending of early adolescence. Brinthaupt and Lipka (2002) also used the ages 10 to 15 as the early adolescent ages.

Changes and Transitions in Early Adolescence

Early adolescence is from the ages of 10 to 15 as suggested, but it is important to note that some preadolescents may reach early adolescence earlier than 10 since "adolescence in the Western world is now recognized as beginning between the ages of 9 and 10" (Balswick et al., 2005, p. 168). Lerner (2002) described, "Adolescence is a period of dramatic challenge, one requiring adjustment to changes in the self, family, and peer group...[and] institutional changes as well" (p. 5). During early adolescence, there are many changes and developments, including: biological and physical changes and physical development, emotional changes, academic changes and transitions, social and sexual and psychological changes, cognitive development, and spiritual development (Brinthaupt \& Lipka, 2002; Feldmeier, 2007; McDevitt \& Ormrod, 2004). 
When discussing the changes in early adolescence, Brinthaupt and Lipka (2002)

stated,

Early adolescence, ages 10 to 15 years, is a time of drastic and superimposed changes in all spheres of functioning (biological, social, and academic). As such it is a time of maximal discontinuity with the past. Therefore, it represents the developmental period of highest stress and challenges but also a time of maximal opportunity. It is a time of heightened susceptibility to influence and there are possibilities for better or for worse...." (p. 30)

\section{Biological and Physiological Changes and Physical Development-Puberty}

In early adolescence, children slowly lose their childlike bodies and make strides towards reproductive maturation, going through the process of puberty and faced with the need to revise their sense of self in relation to a body that is sexually maturing (Dacey \& Travers, 2004; Kelcourse, 2004; McDevitt \& Ormrod, 2004). Early adolescence is the period in life where biological changes are most intense and evident as the human organism becomes reproductively mature and capable of reproduction (Brinthaupt \& Lipka, 2002; Steinberg, 1996). Biological changes occur earlier than social or intellectual changes in adolescents, and consequently, "early physical maturers" are often treated as more socially and emotionally mature than they are, which may have lasting effects on personality development (Dusek, 1991, pp. 10-11).

Puberty

The onset of puberty occurs during early adolescence where significant growth spurts happen as early adolescents first become noticeably heavier and then later grow taller, growing between 6 and $12 \mathrm{~cm}$ in one year (Berger, 1988; Brinthaupt $\&$ Lipka, 2002; McDevitt \& Ormrod, 2004; Steinberg, 1996). Although its timing can vary 
greatly, it was stated that girls reach the onset of menarche on average around 13 to 14 , while some girls experience menarche as early as 9 (Brinthaupt \& Lipka, 2002; Kelcourse, 2004). Today, society would agree that girls reach the onset of menarche much sooner than ever before, on average, around 11 to 12 .

Balswick et al. (2005) found that during puberty, the activation of hormones responsible for pubertal development prompts a significant growth spurt and other biological changes resulting in "the onset of fertility and the experience of increased sexual libido" (p. 171). It has been studied that hormonal changes occurring in early adolescence affects changes in behavior commonly associated with adolescence (Adams, Montemayor, \& Gullotta, 1989; Balswick et al., 2005; Caspi, Lynam, Moffitt, \& Silva, 1993): The physical changes of puberty are orderly and predictable, but early adolescents often experience them as puzzling and disconcerting, looking and feeling awkward (McDevitt \& Ormrod, 2004, p. 21). Brinthaupt and Lipka (2002) summarized, "biological changes in adolescence are not a single event but indicate a complex and long-lasting process that physically transforms the child into an adult" (p. 31).

Hormonal changes and fluctuations in early adolescence affect adolescents' emotions and make them have mood swings (McDevitt \& Ormrod, 2004). Early adolescents also go through negative life events and situational changes because they are associated with adolescent moodiness due to hormonal changes (Berk, 1998). Brinthaupt and Lipka (2002) refer to early adolescence as a "period of social turmoil" (p. 33).

\section{Brain development}

In addition to biological changes, "new research has revealed that the brain undergoes important growth and changes during adolescence" contrary to how it "has 
typically been understood to be completed within the early years of life" (Balswick et al., 2005, p. 172). The brain continues to grow and develop during adolescence. Balswick et al. (2005) noted, "Neurologists think that the frontal lobes of the brain, the part of the brain responsible for functions such as self-control, judgment, emotional regulation, organization and planning may undergo the most significant amount of change during adolescence" (p. 172). Continued development in the front part of the cortex enables adolescents to be able to think about the future, and make rational judgments, have new passions, imagine the future, and temper impulses with thoughts of long-term consequences (McDevitt \& Ormrod, 2004). Killgore, Oki, and Yurgelun-Todd (2001) found that adolescents become increasingly able to analyze emotions at higher levels of the brain, in the cortex, rather than responding to emotions more spontaneously. The significance of these research findings is that the development of the brain, especially the frontal lobes, in early adolescence can potentially affect moral, spiritual and social outcomes among early adolescents.

\section{Academic Changes and Transitions}

During early adolescence, adolescents go through many school transitions. Children move up from elementary school to junior high school or high school. These school changes and transitions place serious stress and anxiety on early adolescents. As early adolescents move from elementary school classrooms to junior high school classrooms or high school classrooms, they find their new environment less personal and their teachers less friendly, less supportive, and less caring than teachers of the previous year in elementary school as their teachers are addressing them as a whole, rather than as small groups or individuals (Brinthaupt \& Lipka, 2002). When early adolescence begins, 
there is an increased need for close relationships and friendships as early adolescents become more socially aware. However, the changing school environment can have a negative impact on early adolescents because students do not have the opportunity to form close friendships or relationships with friends or teachers as they did in elementary schools, since they may find themselves in an unfamiliar environment with unfamiliar people (McDevitt \& Ormrod, 2004, p. 397). Therefore, academic problems often become more pronounced during early adolescence and those who encounter frequent failure become less engaged in school activities (McDevitt \& Ormrod, 2004).

\section{Social, Sexual and Psychological Changes}

When children reach early adolescence, they go through many social changes. One of the most important changes is how much their friends and peers mean to them, and building relationships with them becomes very important to early adolescents. They spend more time with their friends and peers than being with their families, their parents in particular (Larson \& Richards, 1991). Berk (1998) stated, "Puberty is accompanied by psychological distancing between parent and child" (p. 384). Puberty is accompanied by major physical and emotional changes that alter an adolescent's relationship and patterns of interaction with others (Grenell, 2007). Social relationships outside the family become more important, including romantic and sexual relationships, as early adolescents seek social recognition and approval by others, wanting to belong to a popular group, because they are a major concern for them (Brinthaupt \& Lipka, 2002).

As preadolescents reach adolescence, they have distinct beliefs about themselves in at least eight domains: cognitive competence, behavioral conduct, physical appearance, romantic appeal, regard from peers, relationships with close friends, athletic competence, 
and job performance (Harter, Whitesell, \& Junkin, 1998). Dayringer (2000) stated that before early adolescence, preadolescents are egocentric and self-centered, and when they enter early adolescence, their sense of self-centeredness slowly evolves into an interest in developing relationships with others than with just their parents. They become more aware of themselves as social beings, often imagining that everyone is watching them and judging them and that they are the center of everyone's attention (McDevitt \& Ormrod, 2004). McDevitt and Ormrod (2004) called this self-centered aspect of the adolescent self-concept as "the imaginary audience" (p. 398).

Another noteworthy phenomenon in early adolescence is called the personal fable, when they "feel invulnerable and immortal, believing that they are not susceptible to the normal dangers of life" (McDevitt \& Ormrod, 2004, p. 398). This is why early adolescents engage in risky behaviors such as experimenting with drugs, doing dares that compromise their safety, having unprotected sex, and more. There are positive aspects to the personal fable because this sense of invulnerability may encourage young people to venture out into the world and try new things (Bjorklund \& Green, 1992; Lapsley, 1993).

\section{Cognitive Development}

Kelcourse (2004) stated, "The early adolescent is becoming a person who is capable of increasing level of abstraction (Piaget's formal operational thinking), able to get and ponder and critically reflect on the cognitive construct we call an idea" (p. 210). There are a number of studies on cognitive development in early adolescence, and the early adolescent's ability to do abstract thinking (formal operations) was found to be the most significant cognitive development in early adolescence (Balswick et al., 2005; Berger, 1988; Berk, 1998; Bornstein \& Lamb, 1999; Brinthaupt \& Lipka, 2002; 
Dayringer, 2000; Feldmeier, 2007; Gumbiner, 2003; McDevitt \& Ormrod, 2004;

Steinberg, 1996). According to Berger (1988), Jean Piaget, the first theorist recognized what many psychologists now consider the distinguishing feature of adolescent thought, the ability to think abstractly, as "the capacity to think in terms of possibility rather than merely concrete reality (Inhelder \& Piaget, 1958)" (p. 339).

Colarusso (1992) pointed out that early adolescents are now able to reflectcritical assessment and logical evaluation—on the ideas and beliefs of others, especially parents and friends, so as to decide what is "me" and what is "not me".

Balswick et al. (2005) explained abstract thinking in the following,

Abstract thinking includes being able to think hypothetically as well as consider the real and actual, to process information in a sophisticated and complex manner, to consider multiple dimensions of a problem at once, to take other people's perspective and to reflect on oneself. Such abstract thinking is the cornerstone of Piaget's formal operational thought, assumed to begin during adolescence. (p. 172)

\section{Spiritual Development}

Dayringer (2000) observed that adolescents begin to be able to think about "the possible, not just the actual; to reason abstractly about love, religion, and meaning of life" as many become idealists (p. 91). Most teens say that they like church and would attend even it were only up to them. Theologian and psychologist Benedict Groeschel described early and late adolescence as being times of particular importance for religious development (Feldmeier, 2007, p. 118). During teens, it is a time of strong positive or negative feelings about faith and it is marked by profound conversion. The spirituality of early adolescence will be further discussed in the early adolescence spirituality section. 


\section{Summary}

Early adolescence can be summarized as a time of major changes, transitions and possibilities. It is clear that early adolescents experience major changes physically, emotionally, intellectually, socially, sexually, psychologically and spiritually. As early adolescents go through these changes, they are led "inevitably to the desire to function independently of the control of others and to the need to exercise self-governance" (Capps, 2008, p. 29), and "they seek more independence and autonomy" (Balswick et al., 2005 , p. 175). Due to all the changes and transitions early adolescents go through, early adolescence can be a time of surprise, confusion, stress, and challenges. However, the stress and turmoil of this ever-changing period need not be considered as a negative experience. The changes that are ever present in adolescence may actually be considered positively, as a gift of God that should be accepted, cherished and nurtured. Peterson (1994) made a poignant point, "But adolescence is a gift, God's gift, and it must not be squandered in complaints or stoic resistance" and suggested that adolescence should not be reduced to "a problem that must be solved" (p. 5).

\section{Early Adolescence Theories and Spirituality}

As early adolescents transition from childhood to adulthood, they wrestle with the questions of who they are and why they do what they do. They question almost everything in an attempt to find out who they are; as people, as Christians, and as individuals in their own world. They also question how they fit into the adult world and the adult faith. This is the time they grow in their spirituality, if they understand why they do what they do, and begin to understand and comprehend their religious practices and beliefs. 


\section{Developmental Theories of Early Adolescence}

Borgman (2003) said, "If we are to minister to young people with wisdom, we need a clear sense of how young people are meant to grow, what is healthy and what is injurious, and how Christ interacts with natural processes" (p. 94). In this section, developmental theories that are specifically applicable and contributing to early adolescence spirituality will be explored (Borgman, 2003). The theories of Piaget, Kohlberg, Fowler, Gilligan and Kegan will be discussed because these theories use cognitive development as the general rubric for their theories, and they are related to early adolescence spirituality.

Kelcourse (2004) stated,

Cognitive development is the general rubric used to group these theories due to their focus on the development of logic in childhood (Piaget), moral reasoning (Kohlberg), conscious articulations of faith (Fowler), moral decision-making in women's experience (Gilligan), and the conceptual demands of modern life (Kegan). But theorists within this school use the term structural to identify their approach to development. (p. 25)

Vygotsky, the information-processing theory, Anna Freud and Erikson's theories will also be explored in this section because of their relatedness to early adolescent spirituality.

\section{Piaget's Stages of Cognitive Development Theory}

Piaget's stages of cognitive development is considered by some to be "the foundation of developmental cognitive psychology" (Bornstein \& Lamb, 1999, p. 275). Piaget (1954) observed that cognitive development occurs in four qualitatively different stages: sensorimotor stage (birth-24 months), preoperational stage (2-7 years), concrete operational stage (7-11 years), and formal operations stage (12 years and up). Piaget 
believed that it is necessary to complete each stage before the child could progress to the next stage (Novak \& Pelaez, 2004).

Piaget's concrete stage of cognitive development begins at the age of 7 and ends at 11 , followed by the formal operations stage beginning at the age of 12 . However, this does not mean that early adolescents who are between the ages 10-11 are in the concrete operations stage only. It should not be a matter of exact age divisions, but rather, there is fluidity between these two stages in early adolescence. Ginsburg and Brandt (1988) stated, "formal operations, which begins at about age 12 and is consolidated during adolescence" (p. 180), but Gumbiner (2003) suggested that Piaget's formal operations stage actually begins at the age of 11 instead of 12 , thus demonstrating that exact age divisions cannot be limited to those years. The formal operations stage is most evident during adolescence. At the beginning of early adolescence, children transition from the concrete operational stage, during which time adult-like logic appears, but is limited to reasoning about concrete reality, to the formal operations stage when logical reasoning processes are applied to abstract ideas as well as to concrete objects $(\mathrm{McD}$ evitt \& Ormrod, 2004, p. 144). The ability to do abstract thinking (formal operations) is recognized as one of the characteristics of adolescence.

However, most contemporary developmentalists suggest not to take Piaget's stages "too literally" and stated that, "Piaget's four stages are not always accurate descriptions of children's and adolescents' thinking capabilities" but may provide a "rough idea about the cognitive processes you are apt to see at various age levels" (McDevitt \& Ormrod, 2004, p. 160). Many contemporary developmentalists have largely abandoned Piaget's early notions regarding children's cognitive development (McDevitt 
\& Ormrod, 2004, p. 220), but there are some psychologists who instead of rejecting Piaget's theory, developed Neo-Piagetian Theories and continue to recognize Piaget's stages of cognitive development as an important theory for early adolescence.

Steinberg (1996) stated,

Given the emphasis that Piaget placed on the interaction between biological change and environmental stimulation in provoking intellectual growth, it comes as no surprise that early adolescence - a time of dramatic biological maturation and equally noteworthy changes in environmental demands - is viewed in Piagetian theory as an extremely important period in cognitive development. (p. 71)

An evaluation of Piaget's theory differs among researchers, but they all talk about Piaget's theory as it is important in understanding cognitive development in children and adolescents (Amsel \& Renninger, 1997; Berger, 1988; Bornstein \& Lamb, 1999;

Goswami, 2002; Lee, 2000; Lerner, 2002; McDevitt \& Ormrod, 2004; Morra, Gobbo, Marini, \& Sheese, 2008; Novak \& Pelaez, 2004; Pressley \& McCormick, 2007; Richardson, Sheldon, \& University, 1990; Schickedanz, 1998; Siegel \& Brainerd, 1978; Siegler, DeLoache, \& Eisenberg, 2006; Steinberg, 1996; Wood, 1998). McDevitt and Ormrod (2004) stated, "Despite the concerns we have raised Piaget's theory has had a profound influence on contemporary theories of cognitive development" (p. 157).

Regardless of the differences of opinion, Piaget's theory or stages of cognitive development has a place in better understanding early adolescence cognitive development and its effect on spirituality. Piaget's theories of cognitive development in children "have tremendous implications for working with adolescents" (Gumbiner, 2003, p. 29).

\section{Vygotsky's Sociocultural Theory}

Soviet psychologist Lev Vygotsky's work was rediscovered in the 1970s, well after his death at the age of 38 in 1934. Its application to Piaget's constructivism was 
appreciated because Vygotsky put much more emphasis on the role of the social environment in facilitating cognitive development (social constructivism) while Piaget focused on structure and his theory focused more on schemes and stages (Novak \& Pelaez, 2004, p. 226). Unlike Piaget, Vygotsky did not try to devise tasks that would assess different stages of cognitive development, rather, he preferred instead "to observe children's thinking in context, in the settings where children normally spend their time" (Berndt, 1997, pp. 320-321). Novak and Pelaez (2004) stated, "The interest in Vygotsky's theory has been largely the result of three concepts: the zone of proximal development (ZPD), social scaffolding, and cultural tools" which have been "interpreted from a behavior-analytic approach" (p. 226).

Novak and Pelaez (2004) described what the zone of proximal development is according to Vygotsky,

The zone of proximal development (ZPD) is "the distance between the actual developmental level as determined by independent problem solving and the level of potential development as determined through problem solving under adult guidance or in collaboration with more capable peers." (p. 226)

The zone of proximal development (ZPD), simply put, is "the difference between what the child can do alone and what he or she can do with the help of others," and social scaffolding is, "in very general terms, the condition under which the ZPD exists (Novak \& Pelaez, 2004, pp. 226-227).

Novak and Pelaez (2004) explained scaffolding in the following,

Scaffolding is a metaphor grounded in the physical world. Much like iron workers construct scaffolds as safety nets beneath those working higher up, Vygotsky suggested that parents and more competent peers provide supports just below where the children are working to construct their knowledge of the world. The supports, in the form of social prompting, are there when the child struggles and assist the child in getting back to the higher levels of cognitive behavior. Scaffolding is very similar to the behavioral process of shaping. By successively changing the criterion for 
reinforcement, the behavior being shaped more closely resembles the targeted terminal behavior. (p. 227)

According to Vygotsky, scaffolding is important to provide adolescents with support and guidance, however Balswick et al. (2005) pointed out that scaffolding in adolescence "needs to begin to come down, enabling the adolescent freedom to explore and experiment in order to differentiate and develop their own sense of self," otherwise "they can grow overly dependent on others to dictate their belief, values, self-concept and preferences" (p. 184). Still, Vygotsky saw value in having adults describe the discoveries of previous generations, in addition to allowing children to make some discoveries themselves (McDevitt \& Ormrod, 2004). Scaffolding enables early adolescents to become more involved in adult activities where they are given an increased amount of responsibility and independence. This is called guided participation or apprenticeship (McDevitt \& Ormrod, 2004, p. 170). In apprenticeships, children learn the behaviors and the language of a skill or trade and develop these into what is sometimes called a cognitive apprenticeship where children learn how adults typically think about a task or activity from the following: modeling, coaching, scaffolding, articulation, reflection, increasing complexity and diversity of tasks, and exploration (McDevitt \& Ormrod, 2004, pp. 170-171).

McDevitt and Ormrod (2004) found that while Piaget believed that the progression of children's reasoning capabilities is similar across cultures, Vygotsky believed that "the specific cognitive abilities that children acquire depend on the cultural contexts in which the children are raised and the specific activities in which they are asked and encouraged to engage" (p. 181). Piaget's view and Vygotsky's view of children's nature were so different from one another (Siegler et al., 2006). Vygotsky saw 
children as "social beings, intertwined with other people who are eager to help them gain skills and understanding" while "Piaget depicted children as little scientists, trying to understand the world on their own" (Siegler et al., 2006, p. 161). Vygotsky's theory, which is regarded as superior to Piaget's, "emphasized the crucial contributions of social relationships and of language to cognitive development" (Berndt, 1997, p. 321).

Berndt (1997) found the following,

Vygotsky proposed that human thinking and reasoning are products of social activity. As children interact with adults or more capable peers, they not only gain new information but also learn how to think. For Vygotsky, thinking itself is a product of social interaction. (p. 321)

Wood (1998) stated that "One of the most dramatic changes that has taken place in the intellectual climate of developmental psychology and educational theory has come from the impact of Vygotsky's thinking within the field" (p. 40). Bornstein and Lamb (1999) noted that "Vygotsky's theory takes an entirely different approach in emphasizing the role of the environment and social interactions in children's intellectual development" (pp. 291-292). Vygotsky's theory is important for early adolescence spirituality as the sociocultural theories show that social environments, conditions, and interactions do contribute in early adolescent development.

\section{Information-Processing Theories}

Differing from "Piaget's belief that children progress through distinct stages separated only by relatively brief transition periods," information-processing theorists believe that children are undergoing continuous cognitive changes as their cognitive growth occurs constantly, "in small increments, rather than broadly and abruptly" (Siegler et al., 2006, p. 145). Siegler et al. (2006) studied that information-processing 
theorists draw comparisons between the information processing of computers and that of humans, suggesting that just as computers' memory capacity and the efficiency is limited in executing basic operations, "people's thinking is also limited by the same factors: memory capacity, efficiency of thought processes, and availability of relevant strategies and knowledge" (p. 145). Siegel and Brainerd (1978) summarized, "In the informationprocessing view, cognitive development arises from children's gradually surmounting their processing limitations through expansion of memory capacity, increasingly efficient execution of basic processes, and acquisition of new strategies and knowledge" (p. 145). The child is a "limited-capacity processing system."

\section{Anna Freud's Psychological Theory}

According to Dacey and Travers (2004), the daughter of Sigmund Freud, Anna Freud (1895-1983), spent the major part of her professional life "trying to extend and modify psychoanalytic theory as applied to adolescence" and "saw the major problem of adolescence as being the restoration of the delicate balance between the ego and id, which is established during latency and disrupted by puberty" (p. 280). Anna Freud believed that "latency is the time when children adopt the moral values and principles of the people with whom they identify," and "their fears are replaced with internalized feelings of guilt that are learned" during adolescence and "the id is controlled during latency by the strength of the superego" which is at its greatest at puberty (Dacey $\&$ Travers, 2004, p. 280).

Dacey and Travers (2004) further described Anna Freud's psychological theory, The problems brought about by this internal conflict cause the adolescent to regress to earlier stages of development. A renewed Oedipal conflict brings about fears that are entirely unconscious and often produce intense anxiety...The problem, of course, is 
that the use of these defense mechanisms causes new stresses within the individual and tends to further increase the level of anxiety. (p. 280)

In addition, Anna Freud described two additional adolescent mechanisms: "Asceticism, in which, as a defense against the sexual, 'sinful' drives of youth, the teenager frequently becomes extremely religious and devoted to God" and "intellectualization, in which the adolescent defends against emotionality of all kinds by becoming extremely intellectual and logical about life" (Dacey \& Travers, 2004, p. 280). Freud's contribution of a psychological theory in adolescence is important because of her processing physical and sexual changes that early adolescents experience and how she has used it in relation to psychological development.

\section{Piaget's Moral Development Theory}

By observing children playing games, especially marbles, Piaget formulated hypotheses about children's moral understandings and proposed two stages of moral development; the stage of heteronomous morality (preschoolers and children in early primary years) and the stage of autonomous morality (older children) among adolescents. Piaget observed that "children in the stage of heteronomous morality focus on the objective consequences of and action" while "children in the stage of autonomous morality make decisions on the basis of the intentions of the actors" (Pressley \& McCormick, 2007, p. 74).

Pressley and McCormick (2007) further explained Piaget's moral theory,

The heteronomous moral child views rules as sacred, as if they were written by the hand of God, never to be reconsidered. In contrast, the autonomously moral child recognizes that the rules have been agreed upon by the players, that they are inventions of people, and that they can be changed if people will it...Like all Piagetian stages, this one has an invariant order of development, meaning that a child must manifest heteronomous morality before autonomous morality. (pp. 74-75) 
However, according to Siegler et al. (2006), some aspects of Piaget's moral theory have been found faulty by other researchers (Chandler, Greenspan, \& Barenboim, 1973; Grueneich, 1982; Yuill \& Perner, 1988) and he also pointed out that "it is clear that young children do not believe that some actions, such as hurting others, are right even when adults say they are" (Siegler et al., 2006, pp. 535-536). In spite of Piaget's moral theory's shortcomings, his theory provided the basis for subsequent research on the development of moral judgment, including Lawrence Kohlberg's theory of moral development (Siegler et al., 2006, p. 536).

\section{Kohlberg's Moral Development Theory}

Many researchers studied Kohlberg's theory and found his moral development theory important and relevant for early adolescent development (Bee, 1999; Berger, 1988; Berk, 1998; Berndt, 1997; Dacey \& Travers, 2004; Dayringer, 2000; Feldmeier, 2007; Goswami, 2002; McDevitt \& Ormrod, 2004; Novak \& Pelaez, 2004; Pressley \& McCormick, 2007; Siegler et al., 2006).

Another aspect of cognitive development that interested Piaget and other researchers was the child's reasoning about moral questions (Bee, 1999). Bee (1999) pointed out that when children reach adolescence, "several key changes in moral reasoning appear to coincide with adolescence or with the emergence of formal operations reasoning" (p. 460). Piaget was the first to offer a description of the development of moral reasoning, but Lawrence Kohlberg had the most powerful impact as he identified three main levels of moral reasoning. Kohlberg's three levels of moral development are preconventional morality, conventional morality, and principled or 
postconventional morality (Bee, 1999 , p. 461 ). Kohlberg's theory traces moral development through six stages by successive transformations of cognitive structures and each level of morality has two stages (Dacey \& Travers, 2004).

Kohlberg's stages of moral reasoning are, Preconventional morality: focus on self-interest (Stage 1-Focus on obedience and avoiding punishment \& Stage 2-Focus on obtaining rewards or pleasure); Conventional morality: focus on maintaining social order (Stage 3-Focus on being a good boy or a good girl \& Stage 4-Focus on law and order); and Postconventional morality: focus on shared standards and principles (Stage 5-Focus on social contract \& Stage 6-Focus on principle) (Pressley \& McCormick, 2007, p. 78).

Conventional morality which is the second level of Kohlberg's moral development begins when children approach ages 10 to 12 , and the third level, postconventional level of morality comes at age 13 and over (Dacey \& Travers, 2004, p. 234). Feldmeier (2007) suggested that Kohlberg places adolescence at the conventional level, which includes his moral development stages three and four, during which time "maintaining the expectations of one's family or peer group becomes most central" and early adolescents are "very much at this stage" (p. 113).

Pressley and McCormick (2007) stated that adolescents who are in the stages of conventional morality are focused on "maintaining the social order" and "concerned with helping and pleasing others" and do "conformist thinking in the sense of wanting to go along with the majority" (p. 76). Most students in high school advance to Kohlberg's fourth stage with a "law-and-order orientation" and "the appeal now is to the 
maintenance of the group, where one is able to think in terms of principles that go beyond oneself" (Feldmeier, 2007, p. 113).

Early adolescents focus on being a good boy or a good girl and later moving to the next stage focusing on law and order (Dacey \& Travers, 2004; Feldmeier, 2007; Novak \& Pelaez, 2004; Pressley \& McCormick, 2007) as they become concerned with fulfilling their duty to God (Pressley \& McCormick, 2007, p. 77). At stage three, "individuals want to maintain the affection and approval of friends and relatives by being a 'good person' - trustworthy, loyal, respectful, helpful, and nice" and they understand "reciprocity in terms of the Golden Rule" (Berk, 1998, p. 397).

Pressley and McCormick (2007) explained stage four in the following,

Whereas the Stage-3 conventional thinker is concerned with the subjective perceptions of others, the Stage-4 thinker is concerned with being in synchrony with the established standards of his or her society. Those in Stage 4 have a deep respect for law and order. The Stage-4 person is concerned with doing his or her duty to country, God, spouse, or whatever else commands allegiance by social standards.

Dacey and Travers (2004) found that according to Kohlberg, "moral judgment requires us to weigh the claims of others against self-interest" and so, "youngsters must overcome their egocentrism before they can legitimately make moral judgments" (Dacey $\&$ Travers, 2004, p. 234). Kohlberg's theory demonstrated that there are relatively systematic changes with age in children's moral judgment and his thinking has been useful in understanding how cognitive processes contribute to moral behavior, but also generated "a flurry of controversy and criticism" (Siegler et al., 2006, p. 539).

\section{Gilligan's Theory of Gender Differences in Morality Reasoning}

The most hotly debated issue regarding Kohlberg's theory is whether there are 
gender differences in moral judgment (Dacey \& Travers, 2004; Feldmeier, 2007; Pressley \& McCormick, 2007; Siegler et al., 2006). Gilligan (1982) argued that Kohlberg's classification of moral judgment is biased against females and suggested that, because of differences in their socialization, males tend to value principles of justice and doing what's right while females value caring, responsibility for others, and avoidance of exploiting or hurting others (Siegler et al., 2006). In adolescence, "girls often develop moral vision that is directly related to care of others and a mutuality of relationships" and are "more interested in the quality of their relationships," while boys are more competitive and "likely to begin to devise rules of fair play in games where there will be winners and losers" (Feldmeier, 2007, p. 114). According to Gilligan, women's moral decisions are based on an "ethics of caring" rather than a "morality of justice" (Dacey \& Travers, 2004, p. 235).

Siegler et al. (2006) found that "Contrary to Gilligan's theory, there is little evidence that boys and girls, or men and women, score differently on Kohlberg's stages of moral judgment," but consistent with Gilligan's arguments that "during adolescence and adulthood, females focus somewhat more on issues of caring about other people in their moral judgment" (Siegler et al., 2006, p. 540).

\section{Kegan's Constructive Developmental Theory}

Eriksen (2008) described Kegan's constructive developmental theory stages (Kegan, 1982, 1994) in the following,

Kegan $(1982,1994)$ outlined six stages, which he also sometimes referred to as balances or orders of consciousness, in constructive development: (a) the Incorporative Balance, in which reflexes are primary (Stage 0); (b) Impulsive Balance, in which knowing is only about one's own immediate impulses (Stage 1); (c) the Imperial Balance, in which the individual is aware of her or his own experiences as 
well as another's experiences (Stage 2); (d) the Interpersonal Balance, or Romanticism, in which abstractions and more mutual relationships become possible (Stage 3); (e) the Institutional Balance, or Modernism, in which understanding of systems, greater autonomy, and self-authorship become possible (Stage 4); and (f) the Interindividual Balance, or Postmodernism, in which people become the directors and creators of systems, understanding how systems fit together meaningfully (Stage 5). (p. 235)

Eriksen (2008) explained Kegan's "subject-object relationship" in the following,

In particular, Kegan (1994) indicated that the "deep structure of any principle of mental organization is the subject-object relationship" (p. 32). He considered those things "object" that people could "reflect on, handle, look at, be responsible for, relate to each other, take control of, internalize, assimilate, or otherwise operate on" (p. 32). He considered those things "subject" that people were "identified with, tied to, fused with, or embedded in" (p. 32)...The notions of subject and object might be illustrated by the commonly known adage "the fish is the last to understand what water is." In this metaphor, the fish is subject to the water, and people who are looking from outside the bowl at the fish in the water are able to make the water object. (p. 235)

Feldmeier (2007), applying Kegan's theory, talked about one being able to think in terms of principles that go beyond oneself,

Kegan describes this stage succinctly. What is right? It is living up to what is expected by people of importance to you. Being good also means having good motives, such as showing concern for others and keeping mutual relations of trust, loyalty, and so on. What are the reasons for doing right? They are to be a good person in your own eyes and those of others, and the desire to maintain rules and obey the authorities that support stereotypical behavior. What is the social perspective? It is that of an individual in relationships with others, with an awareness of shared feelings, agreements, and expectations. Kegan even states that such a social perspective takes priority over one's personal interests. (p. 114)

\section{Erikson's Theory—Identity and Period of Moratorium}

According to Erik Erikson (1902-1994), who originated the term "identity crisis" (Erikson, 1963, 1975), the main task of the adolescent is to achieve a state of identity which is the fifth stage of his psychosocial developmental stages (Dacey \& Travers, 2004; McDevitt \& Ormrod, 2004). Erikson proposed eight age-related stages of 
development from infancy to old age: Stage 1 -Trust versus mistrust (infancy), Stage 2-Autonomy versus shame and doubt (toddler years), Stage 3-Initiative versus guilt (preschool years), Stage 4-Industry versus inferiority (elementary school years), Stage 5-Identity versus role confusion (adolescence), Stage 6-Intimacy versus isolation (young adulthood), Stage 7-Generativity versus stagnation (middle age), and Stage 8Integrity versus despair (retirement years) (McDevitt \& Ormrod, 2004, pp. 407-410).

Pressley and McCormick (2007) stated that "For Erikson, what mattered were key social interactions at each stage of development" (p. 145). When children transition from childhood to adolescence, they go through the fifth stage-identity versus role confusion, wrestling "with the questions of who they are and how they fit into the adult world," have "mixed ideas and feelings about the specific ways in which they will fit into society" and may experiment with a variety of things (McDevitt \& Ormrod, 2004, p. 409). According to Erikson, because of the many changes they are experiencing at this time, adolescents feel a need to revise their sense of self in relation to the new body they are acquiring (Kelcourse, 2004). As they begin to question their parents, they attempt to find their own place in society, and their peers become more and more important, but change frequently as a way of "trying on new identities" (Kelcourse, 2004, p. 77).

This identity crisis that adolescents experience is demonstrated in four major areas: career, morality and religion, political ideology, and social values (Dayringer, 2000, p. 91). In the adolescents" search for a new identity, they search for a "self within something bigger than themselves [to] affirm their sense of uniqueness and independence" (Balswick et al., 2005, p. 178). "Erikson names identity formation as the definitive developmental task of adolescence... [which] also includes the importance of 
developing a sense of mastery and intimacy" (Balswick et al., 2005, p. 169). In their endeavor of searching for their true identity, adolescents have the opportunity to explore new identities.

This period of exploring new identities Erikson calls moratorium and claims that this is central to the adolescent's experience (Balswick et al., 2005, p. 179). Erikson stated that "Young people need a moratorium...for developing an identity of their own and for gaining the independence needed for acting as self-responsible modern individuals" (Lefebvre \& Ross, 2007, p. 80). As adolescents have the opportunity to experience different identities, they do not assume responsibility for the consequences of any particular one. This indecision is an essential part of the moratorium and tolerance of it by parents and others in the adolescent's life leads to a positive identity (Kelcourse, 2004, p. 280).

After experimenting with different identities, once the adolescent commits to one identity and claims it as his or her own, Erikson calls this fidelity (Balswick et al., 2005). "For Erikson, fidelity is an unflagging commitment to an ideology that transcends the self and brings about genuineness, sincerity and a sense of duty to others" (Balswick et al., 2005, p. 179). After fidelity has taken place, repudiation is necessary. The adolescent must give up all other possibilities for the sake of their one true identity. However, there are those who cannot do this. They become those people who "cannot keep a job, they have no loyalty to their friends, they are unable to be faithful to a spouse. For them, the grass is always greener on the other side of the fence" (Kelcourse, 2004, p. 281).

If an adolescent hastily makes choices too early, they usually come to regret them. They will become more vulnerable to identity confusion later in life (Kelcourse, 2004). 
Dayringer said it best as he summarized: "The overall task of adolescence is to develop a sense of personal identity and positive self-esteem, to become autonomous and socially responsible, to enjoy work and play, and to be capable of making mature decisions" (Dayringer, 2000, p. 101).

\section{James Marcia's Identity Status Theory}

Based on Erikson's work on identity and psychosocial development in the 1960s, Marcia (1966) refined and extended Erikson's theory and came up with four points of psychological identity development: (a) Identity diffusion-the adolescent does not know about having choices and has not made a commitment, nor wants to, (b) Identity foreclosure-the adolescent seems willing to commit to some roles, values, or goals for the future, but tends to conform to the expectations of others (e.g. following a career suggested by a parent). Thus, these youth have not explored a range of options, (c) Identity moratorium - the adolescent is in a crisis, exploring various commitments and is ready to make choices, but has not made a commitment to these choices yet, and (d) Identity achievement—-the adolescent has experienced an identity crisis and has made a commitment to a sense of identity that he or she has chosen. These are not stages and should not be viewed as a sequential process. The fundamental idea is that one's sense of identity is determined largely by the choices and commitments made regarding certain personal and social traits (Marcia, 1966).

\section{James Fowler's Theory—Stages of Faith}

Balswick et al. (2005) described Fowler's theory, “James Fowler (1981) proposed a theory of faith development that emphasizes the motivation to discover meaning in life, 
either within or outside of an organized religion" (p. 269). Fowler identified six stages of faith development that explained how religious and spiritual development occur, from infancy to late adulthood beginning from "primal faith": Stage 1-Intuitive-projective faith (early childhood), Stage 2-Mythical-literal faith (middle and late childhood), Stage 3-Synthetic-conventional (adolescence), Stage 4-Individuative-reflexive faith (emerging-young adulthood, Stage 5-Conjunctive faith (middle-late adulthood), and Stage 6-Universalizing faith (middle to late adulthood) (Balswick et al., 2005, pp. 269272).

Adolescents begin to give evidence of synthetic-conventional faith (Fowler's third stage), as they "begin to integrate what they have learned about religion into a coherent belief system and sense of identity," and have a deeper understanding of self while they "become concerned with their identity, vocation and future" (Balswick et al., 2005, p. 270). Balswick et al. (2005) noted that during this stage, as adolescents take God in depth, "the desire for personal relations with significant others is often associated with a hunger for a personal relationship with God in which a young person feels known and loved" and "[w]hen an adolescent faces the identity crisis, often this sense of knowing God leads to a deep integration of God into identity" (p. 270). At this stage, the adolescent's increased ability to think abstractly allows them to apply this to their understanding of religion and faith.

They begin to step outside their set of beliefs given to them by their parents, and question them, however, they are unable to step outside of their faith and critique it with an outside perspective (Feldmeier, 2007). At this stage, religious authority starts to come from within and the adolescent becomes more "self-authorized" (Feldmeier, 2007, p. 
115), however, it is only an initial step. They continue to be dependent on their parents' belief. Fowler believed that most adolescents demonstrate synthetic-conventional faith, and he found that some adults had not stepped beyond this stage of faith as well (Feldmeier, 2007, p. 115).

\section{Identity and Spirituality}

Amidst all the challenges of awkward and confused adolescents lies a gift, a gift given by God where these early teens become spiritually pressed to find meaning in their lives, struggling to find their own identity in the world, an identity that lies in a new journey of discovering their own walk with God. As adolescents doubt what they have heretofore taken as undoubted certainty, the beliefs taught to them by their parents, they begin to question these, wanting to create for themselves their own religious experience. "They want to exchange their secondhand religion or belief system for firsthand experience" (Dayringer, 2000, p. 98). M. King (2006) stated that youth "...want to encounter God. They want authenticity. They long to know and experience Christ and embrace something that calls them to a sacrificial challenge" (p. 64).

Feldmeier (2007) also states that stereotypes of teens who believe church is boring or irrelevant are inaccurate. In fact, most teens would attend church even without encouragement from parents (Feldmeier, 2007, p. 117). Theologian and psychologist Benedict Groeschel describes early adolescence as a time of significant importance for their religious development and can be a time of profound religious conversion. $\mathrm{He}$ supports this claim with the fact that "adolescence is a time when one is seeding the foundations of an identity" (Feldmeier, 2007, p. 118). Resistance to church, or questioning of parents is not a step away from God, but rather a natural development in 
discipleship (Peterson, 1994, p. 27). Because of their developmental need at this time, adolescents need to perceive God as a friend or companion, rather than a judge, who will help them through this tumultuous time of their lives, who will accept them even though they struggle to find their own identity and have difficulty accepting themselves (Feldmeier, 2007, p. 120). Regular participation in a faith community instills a critical sense of belonging in youth, and hands-on personal experiences that help them make sense of their faith such as community service projects are invaluable (Feldmeier, 2007). Adolescents "need and hunger for experiences of transcendence appropriate for them, including prayer groups, paraliturgies, faith discussion groups, and so on. In short, adolescents need opportunities to share faith (their inner life) and faith experiences (real engagement with the divine) with other friends and trusted adults" (Feldmeier, 2007, p. 123).

As they struggle to find their own faith identity, the support of parents and others in taking their questions and ideas seriously, and searching together for answers to questions that really matter will enable their sense of self-worth to grow. "Young people are tired of our words about God and are waiting for deeds of solidarity and justice. It is important for them to have experience of the word which enables them to discover the word of God" (Lefebvre \& Ross, 2007, p. 92).

\section{Early Adolescence Mentoring and Discipleship}

Early adolescents who are going through changes and transitions are often confused and discouraged and need someone who can help them make sense out of a rapidly changing world. Borgman (2003) points out that "the divine intention for all human beings is that they become, through families and society, all the Creator intended 
them to be" and to hinder "God's intended growth in a child is therefore a terrible evil" (p. 58). He also states that "God did not make growing up easy" and "the Chief Shepherd has entrusted the rearing of children to lesser shepherds" (Borgman, 2003, p. 58).

Novak and Pelaez (2004) point out the following,

Vygotsky's theory extends the mind "beyond the skin" that "the development of thinking and cognition is the result of the child's interactions with the external social environment, particularly parents; more advanced peers; and the cognitive tools, such as language and books that society provides. Thus, in this view, cognitive development is learned through social interaction and not simply through the child's solo actions. (p. 227)

According to McDevitt and Ormrod (2004), the National Middle School Association (NMSA) offers guidelines for meeting the developmental needs of 10 to 15 years olds and recommended that "every student be supported by one adult (an advisor)" who watches the academic and personal development of early adolescents, believing that the "advisor-student relationship, when stable and positive, can help young adolescents weather the rapid developmental changes—not only physical, but also cognitive and social-that they are likely to experience" (McDevitt \& Ormrod, 2004, p. 21). NMSA suggested that large middle schools be subdivided into "houses" or other small units to build closer relationships with classmates and teachers, thereby allowing early adolescents to be mentored by these advisors. The recommendations of NMSA recognize and reflect the challenges early adolescents face and show the importance of building a close and personal supportive system between early adolescents and their peers and teachers.

Early adolescent mentoring and discipleship begins by accepting adolescents as they are. Feldmeier (2007) suggested that "perhaps the most important ministerial posture an adult can bring to a teen is acceptance" as teens most respect and want to 
emulate adults who respect them and who make them feel special and valuable (p. 125). As early adolescents go through changes, those changes can bring discouragements and disappointments, but true acceptance can relieve them from a sense of defeat and devastation.

Feldmeier (2007) shared a story from Anthony de Mello,

I was neurotic for years. I was anxious and depressed and selfish. Everyone kept telling me to change. I resented them, and I agreed with them, and I wanted to change, but simply couldn't, no matter how hard I tried. What hurt the most was that, like the others, my best friend kept insisting that I change. So I felt powerless and trapped. Then one day, he said to me, "Don't change. I love you as you are." Those words were like music to my ears: "Don't change. Don't change. Don't change...I love you as you are." I relaxed. I came alive. And suddenly I changed! Now I know that I couldn't really change until I found someone who would love me whether I changed or not. (p. 109)

\section{Parent Mentoring}

"Young teens are parented by alarm clocks," said Kelcourse (2004, p. 208), stating that in todays' society, parenting or parent mentoring is lacking, if not altogether absent in the lives of many young people. Kelcourse (2004) studied that the proximity of parents is a critical variable in healthy human development, but nowadays parents are less available and peers are becoming a more powerful influence to young people than parents. All the studies show that young people need deeper relationships with their parents (Borgman, 2003, p. 372).

As children transition into adolescence and enter "the second decade: the willing self" (Capps, 2008), "parent-child interactions are often experienced by both as scenes of combat," but it is vitally important that "the child experiences some victories and some defeats" as they develop their own "human strength or virtue of will" (pp. 28-29). Capps (2008) noted that "The very idea that will is a virtue means that the child is developing a 
will that is fundamentally good" and "Judicious parenthood will gradually grant a measure of self-control to the child who learns to control willfulness, to offer willingness, and to exchange good will" (p. 29). Capps (2008) stated that according to Erikson, "the child's sense of autonomy depends on 'the dignity and the sense of personal independence' that the parents derive from their own lives" (p. 36). Relationship between parent and adolescent should not be a matter of winners and losers, but a mutual limitation of wills (Capps, 2008).

Teenagers have an ambivalent relationship with their parents, and they often appear to be dismissive and distant, making their parents feel that they have lost their influence in shaping the lives of their teenage children, but for most teens, "this conclusion is absolutely false, and for several reasons" (Feldmeier, 2007, p. 117). Balswick et al. (2005) pointed out that despite conflicts with other issues, parents and their adolescent children agree more than they disagree regarding core values. Adolescents "more frequently agree with their parents' views than their friends' views on major issues such as religion, politics, importance of education and morality," while peers have more influence on such things as "clothing style, music and activity choice" (p. 175).

Feldmeier (2007) explains the importance of parenting or parent mentoring in the following,

Parents establish expectations, define what is a normal, model lifestyle, set boundaries, and so forth. Indeed, with regard to faith the weight of sociological data suggests that parents are the most important influence in shaping teens' religious lives by modeling their own faith. In short, the importance of faith for teens closely aligns with the importance of faith for their parents. The truth is, parental influence dominates teen development broadly, for good or for ill. (p. 117) 
It is the steady and reliable presence of the parent that fosters healthy human development in young people as parents become available, especially when their children are in need. As early adolescents go through many changes, transitions, and challenges, "parental mirroring can be especially meaningful to ameliorate the natural fears and concerns that early teens experience" (Kelcourse, 2004, p. 215). Parents play a very important role in the lives of adolescent children, and having a strong sense of shared values, beliefs, and goals with parents is strongly related to moral outcomes and religiousness among youth (Balswick et al., 2005).

\section{Non-Parent Mentoring/Discipleship}

As children become adolescents, they begin to gravitate toward their peers and become less attentive to their families, progressively differentiating from their families, as they seek the support of, and guidance from, other adults (Balswick et al., 2005). Balswick et al. (2005) observed that "The general stereotype of adolescence is that biological changes of puberty create a developmental disturbance of emotional and social turmoil and problem behaviors" (p. 167), and too often adults are influenced by these negative stereotypes of adolescents, and fear them in their own community, that they are reluctant to engage with them (Balswick et al., 2005; Scales, 2003).

Balswick et al. (2005) shared the stories of two youths in the following, At a "Youth Sunday" in a church in the Los Angeles area, one senior in high school pleaded with the adults to engage the youth in the congregation. His message implored the congregation to come together and be like a family. He beckoned the adults to talk to the youth - even if they seem intimidating and listen to loud music. His message was clear that the youth longed for adults to engage them. Another senior girl articulated the potential impact adults could make on youth. She communicated to the adults that youth need to know that they matter. She talked about how potentially influential the adults in their congregation could be on the youth. She thought that if the adult members of the church trusted and believed in the 
youth and treated them with more potential than as "weirdos" who dress strange and listen to strange music, then they would be empowered to do something for their society through God. She wanted to hear that she mattered to the adults. (p. 178)

Adolescence is an intense period of growth in which young people need the presence of others, their genuine interest, encouragement and guidance in order for them to become contributing members of the society (Balswick et al., 2005). According to Borgman (2003), highly respected pediatrician and author Eli Newberger studied and found that, among the five things kids need, the first thing young people need is "At least one adult in their lives who is crazy about them (parents are best, but studies show another caring adult will do)" and this highlights the importance of having a mentor, a parent mentor or a non-parent mentor who loves them (p. 70). Borgman (2003) also finds that "every major study concludes that young people need deeper relationships with their parents and/or other interested adults" (p. 372). However, similar to parents, mentoring adults are most effective when they provide not only affection and encouragement to adolescents, but also provide guidance, empowerment and accountability (Balswick et al., 2005).

Kelcourse (2004) states the importance for early adolescents to find role models outside the home whose values they can emulate and respect as they seek to differentiate from their parents to prepare for adult independence (p. 78). As early adolescents go through their fluctuating and vulnerable sense of self and their need for adult mentors outside family, faith communities can be a positive source of moral support (Kelcourse, 2004). Lefebvre and Ross (2007) find that "if children experience that their own ideas are taken seriously, that they can search together with others, including with an adult 
(teacher), for answers to questions that really matter, their sense of self-worth can grow (p. 61).

Balswick et al. (2005) stated,

Adult support can take place through formal mentoring programs or in natural relationships in school, neighborhood or a congregation. These relationships are most effective in promoting positive outcomes in youth when they are characterized by trust, positive social interaction, communication and having a sense of shared values (P. E. King \& Furrow, 2004). (p. 177)

Mentoring is crucial today because many youth are "relational refugees" (Wimberly, 2000), that is, those who have physical parents, but who still feel like they are alone to negotiate the difficulties of life, because they feel abandoned by their parental mentors (Kelcourse, 2004, p. 121). Borgman (2003) finds that "youth at risk need big brother/sister, mother/father; and grandparent figures" and "motherless and fatherless boys can be reparented" (p. 201). Kelcourse (2004) notes that youth today desperately need mentoring from someone who can guide them into a meaningful life. He stated that mentoring is comprehensive and it is more than just role-modeling. It is being presented to make persons who feel homeless and abandoned feel at home as this kind of mentoring involves several levels of "mimetic activity" (Kelcourse, 2004, p. 121).

Borgman (2003) shares a story of a non-parent mentor,

He wasn't a youth worker in the ordinary sense, nor a pastor or teacher, but he did make a difference. He was just Marty Pino, who worked a variety of jobs, and for a time ran Marty's Ice Cream Shop in East Boston-until it closed because he gave so much away to kids who didn't have money. Besides his regular jobs, he coached Tball and led kids at summer camps. For many years he would get up early to take some of his neighborhood's most lonely and hungry to breakfast on the way to taking them to school-making sure they wouldn't skip. He was a father figure for many and every Father's Day would receive cards: "Thank you, you were my real father. I didn't have a father," signed "The Breakfast Club." (p. 181) 
Ezekiel 34 implies a challenge for people to be good shepherds of youth, and that youth leaders who do God's will and follow Christ are especially called to be faithful human shepherds in their care of the young (Borgman, 2003, p. 59).

Balswick et al. (2005) find the following,

A study of individuals who demonstrate an extraordinary commitment to caring for those in their communities report having adults in their life who came alongside of them and affirmed their gifts and vision, encouraged them in their service to others and helped them clarify their beliefs. (p. 177)

\section{Peer Mentoring}

When children become adolescents, "peers-peer groups, peer pressure and so forth" become very significant to them (Balswick et al., 2005). At the same time, studies showed that as "adolescents begin to gravitate toward their peers, they become less attentive to their families" (Balswick et al., 2005). Balswick et al. (2005) state that "conformity to peers raises susceptibility to negative peer pressure as well", but also pointed out that "most researchers do not accept the simplistic view that peer groups are primarily bad influence during adolescence" (p. 175). Contrary to what some may believe, it was researched that "in fact, youth tend to spend time with peers who hold views similar to those of their parents on the major issues" such as religion, politics, importance of education and morality (Balswick et al., 2005, p. 175).

Borgman (2003) describes in the following, a new pilot scheme which was implemented for peer mentoring,

Another new scheme selects older students to mentor younger pupils in local schools. These mentors will develop relationships and then help with homework, organizing time, and personal problems. They will be there to hear the stories of their younger peers. British experts found little or no correlation between success and the age or education of tutors. The key to helping is rather empathy - mentors who care, can 
listen, and respond. All studies and specialists agree to this critical need for someone to care. (p. 372)

As adolescents gravitate more and more towards the influence of their peers, they are often negatively influenced on many different issues, however, positive peer mentoring can be equally as influential in providing the adolescent with positive choice opportunities by creating friendships with peers who would influence them in a constructive way:

\section{A Good Mentor}

M. King (2006) says that being a good mentor or "being a spiritual guide to youth means taking them with you on your journey and allowing them to be a part of your pilgrimage, just as you are on their journey with them" (p. 67). Borgman (2003) states, "it will take love, perseverance, and skill before they open up" (p. 372). A good mentor is someone who is patient, gentle, and committed: Someone who is enduring and persistent in spite of rejections and disappointments. A good mentor never gives up.

Borgman (2003) describes good role models in the following,

Good role models often care more about young people than young people care about themselves. Such care should say, "I want the best for you. But I will be here for you if you choose less than the best. When you falter, we will together seek solutions." (p. 351)

However, taking mentees on a mentor's life journey, caring for them more than a mentor cares for himself/herself, or being there for them alone is not enough for one to be a good mentor. A good mentor must become a living example to a mentee. Just as a rabbi was a living example for a talmid, a good mentor should be able to influence his student through what he said and what he did, impacting the student's life through his teaching and conduct, and more with his example than his words (Krallmann, 2002). 
Krallmann (2002) quotes M. Friedman's articulation of this important point, "The words of the rabbi were precious, his example, more precious still" and he described how "rabbi exemplified for the aim of imitation and his students were in addition expected to observe and emulate" (p. 33). A good mentor is REAL (R-Relational; E-Exemplary, Encouraging and Empathetic; A-Authentic; and L-Loyal, Lowly \& Loving) to his or her mentees. A good Christian mentor must reflect the true attributes of Christ, exhibiting Christlikeness to those under his/her care, first becoming a genuine and faithful talmid of The Rabbi Jesus and then to make disciples for Jesus Christ.

\section{Early Adolescents Mentoring and Discipleship}

Peterson (1994) states, "the most significant reality in adolescent development is a relationship with God" (p. 16), and ministering, mentoring and discipleship for early adolescents are becoming more and more important as there is an increased awareness and understanding of the importance of early adolescence. Church youth programs which only a few years ago focused on high school teens are reaching down to include middle school students (Kelcourse, 2004, p. 206). More and more people are becoming aware and recognizing the importance of early adolescent's mentoring and discipleship.

\section{Conclusion}

Achieving a sense of identity is the major developmental task of adolescents (Parrott, 2000). Borgman (2003) describes the importance of parents, teachers, and youth leaders caring about young people in the following,

Parents, teachers, and youth leaders who care about kids and are concerned about negative factors in the culture can provide positive alternatives and models of excitement without danger, adventure without damage, and fulfillment without 
remorse. Communities can encourage and support those who will look for and spend time with rebels who wander the streets. (p. 202)

With this kind of support from parents, teachers, youth leaders and even peers, an adolescent will begin to discover his/her sense of identity as they learn of the Christ-like characteristics depicted by their mentor. They will learn the true meaning of life, that is, to serve others through selfless acts of love, just as Christ did. As their sense of purpose in life to self-sacrificially love others as Christ did becomes stronger and clearer, their identity crisis will slowly dissipate until they have reached the point of witnessing, experiencing and now, in turn, mimicking the example of Jesus that they have witnessed from their mentor. Although adolescents may be exposed to a number of negative influences, the opportunities for positive choices increases with the mentorship they receive, and as they witness their mentor's spiritual journey with Jesus, the ups and downs, the wrong choices the mentors themselves make, how they repent, ask forgiveness, receive the grace of Jesus and continue in their walk with the lord, the adolescents will develop for themselves their own personal relationship with Jesus. As they struggle to find their sense of identity, with the help of their mentor, they will find their true sense of identity in their personal walk with Jesus, learning of Him, becoming like Him and eventually, also leading others to Him through peer mentoring. 
CHAPTER 4

\section{PROJECT DEVELOPMENT AND NARRATIVE \\ OF PROJECT IMPLEMENTATION}

\section{Introduction}

I began my ministry at the Kitchener-Waterloo Seventh-day Adventist Church (KWSDAC) in September of 2002. Over a decade of my ministry in the church, I was able to execute both long-term ( 7 years) and short-term ( 7 months) projects in mentoring and discipling early adolescents and adolescents. Intentional ministry for the youths and young adults of the church began in 2002 and intentional mentoring and discipleship began in 2006 until 2013, when in 2012 the short-term mentoring and discipleship project for early adolescents took place. In 2006, when the intentional mentoring and discipleship program/process was implemented, I was cognizant about the theology of mentoring and discipleship and the theology was integrated in the mentoring process. In this chapter, both intentional ministry for the youth and young adults, and intentional mentoring and discipleship for the early adolescents and adolescents will be described in greater detail. 


\section{Kitchener-Waterloo Seventh-day Adventist Church}

\section{History}

The Kitchener-Waterloo Seventh-day Adventist Church (KWSDAC) was organized as a church in 1951. The church is located in the city of Kitchener, which is known as Little Berlin, and has a rich European cultural heritage, especially from Germany. The first generation of the KWSDAC is predominantly of German descent. However, the church became more diverse and multicultural as the demographics changed over the past 50 years. During the 1980s to 1990 s, KWSDAC transitioned from a homogeneous group to a multicultural group, and I became the first non-Caucasian minister for the church. When I arrived in September 2002, the ethnic makeup of the church was about $50 \%$ Caucasian and $50 \%$ non-Caucasian. Since then, more people of the West Indian descent arrived. Thus, they became the majority group comprising over $50 \%$ of the church membership while people who were not of the West Indian descent became less than $50 \%$ of the church membership. The largest membership of the Adventists in Ontario, Canada is composed of West Indian descent. The German Sabbath School class that existed at the time for the seniors who did not speak English, met regularly until the beginning of 2007 . As the church aged, so did its members, and many passed away. The number of children significantly decreased to a point where there were many challenges to maintain an effective children's ministry.

\section{Challenges}

From 1951 to 2013, the KWSDAC had only one family from its founding generation that had its children and grandchildren attending and active in the church. Most of the second and third generation members of the church who once attended, no 
longer did, neither did they practice their inherited Adventist religious beliefs. This resulted in a decrease in church membership and a decline in participation in the children's ministries program, thus making it unsustainable. As a result of a lack of children and youth, there was a great challenge in providing both children's ministries and youth ministry. It was observed in 2002 that the children's ministries and youth ministry were struggling to be effective. I found that many of the older Millennials, who were at that time between the ages of 19-23, felt that their needs were not being met. There were less than 10 young adults and even fewer children. They felt that there was no relevant ministry for them in the church and showed very little interest in programs that were available.

\section{Change in Youth Ministry Approach}

As a result of the many challenges of retaining and reclaiming the youth in the church, the church leadership decided to particularly focus on the older children between the ages of 8-10 and the early adolescents between the ages of 10-15. The rationale was that if the church could mentor and disciple them early on, we would have a better chance of keeping them in the church, rather than having to go out and reclaim them once they became less than enthusiastic about attending church regularly. This was the beginning of the intentional ministry and mentoring and discipleship program/process in the KWSDAC. It began in 2002 after my arrival as the new pastor in a desperate attempt to address the issue of the decreasing membership of the church, particularly of children and youth. The word "program" in the phrase "mentoring and discipleship program" will be used interchangeably with the word "process" as the word "program" was intended to express the "process" rather than an event or an activity. 


\section{Observation and Intervention-Laying the Youth Ministry Foundation}

\section{Introduction}

At the onset of laying the youth ministry foundation, I endeavored to solicit the support of other adults in the church who would commit to becoming a mentor to the youth. Five adults in particular became more involved in the youth ministry of the church through their regular presence, participation and support of the youth ministry programs. Their dedication and commitment increased as they became mentors to the youth in many different ways. Three of the adults attended mission trips, one led the youth Bible study class and one other adult, including one of the mentors who attended the mission trips, were regularly present at youth functions, including the youth FNL Friday night vespers service, and social nights. Their involvement with the youth was not limited to these three events, but these were rather a starting point for the relationships that then ensued.

For example, one of these adults is an elderly lady who took on the role of an "adopted" grandmother, caring for the youth unconditionally with her regular hugs, feeding them, attending every mission trip, every youth social event, and Friday evening vespers. Two of the adults were considered as "uncle" and "aunt" so-and-so, who were the playful, yet disciplinary mentors the youth could count on as a non-parent mentor. The last of the five taught them about the Bible and became a friend to them, looking past their shortcomings and mistakes, and seeing in the youth their uniqueness and accepting them for who they are.

Their contribution provided great support and resources allowing me to develop and implement the intentional mentoring and discipleship program. In turn, they 
witnessed the birth of the "FOLLOW ME" mentoring and discipleship program/process and thus received the training themselves to also eventually become mentors in the program.

All the mentors were subjected to prior screening and police clearance before they were allowed to provide care, nurture, mentoring and discipling for the young people. In addition to these five adult mentors, five K-WAY youth leaders exerted their influence as peer-mentors to the other youths and young adults of the church which has had a significant impact in the youth mentoring and discipleship program/process of the church.

\section{First Year of Intentional Ministry}

\section{September 2002-December 2002}

During this period, it was observed that there was a great need to organize and restructure the children's ministries due to a lack of children's Sabbath School teachers. It was assessed that the church was getting older, quite literally since 1951 when the church was first organized. It was also assessed that the financial funding of the church for the children's ministries and youth ministry was weak and thus we began to collect the lamb's offering after the children's story time to support the children's ministries. It was observed that since that decision to collect the lamb's offering, there has always been a sufficient fund to support all the children's ministries expenses and some youth ministry expenses. Social events, church lock-ins, nature walks, gym nights, movie nights, games nights, and other social events were organized for the youth to keep them interested and involved in the church. 


\section{January 2003-August 2003}

The theme "Unity in Diversity" was frequently emphasized since the church had become more diverse and multicultural after an influx of new members of many different cultures and ethnicities over the last 50 years. A new vision was cast by the church leadership to prioritize the church's ministries in the following order: (a) Children's ministries, (b) Youth ministry, (c) Seniors' ministry, (d) Young adult ministry, followed by other ministries. The Children and Youth Ministry Advisory Committee (CYMAC) was organized to solicit and coordinate children and youth ministry's resources. University students and other young adults were encouraged to attend an AMiCUS (Adventist Ministry to College and University Students) spring retreat; the youth and young adults along with the pastor attended this retreat for the first time.

\section{Second Year of Intentional Ministry}

\section{September 2003-December 2003}

A youth evangelistic series was held to reclaim and reenergize the inactive and passive youths and young adults in an attempt to increase spiritual enthusiasm among them. Some attempts were made to have social gatherings, but this did not generate too much interest by the youths and young adults.

\section{January 2004-August 2004}

After the first year of intentional youth ministry, it was assessed that all the efforts to reach out to the inactive/passive older youths and late adolescents were not as effective as intended and the decision was made to focus on the older children between the ages of 8-10 and the early adolescents between the ages of $10-15$ as a case study to see whether 
this new approach would have better success in retaining them in the church as they grow older. The rationale was that it is better to nurture and mentor them early on so that they would not leave the church, than to see them leave the church and later try to reclaim them. This new approach in youth ministry was intentionally, but subtly executed. Much of the church's human resources were directed to mentoring and nurturing these older children (ages 8-10) and the early adolescents (ages 10-15). The decision was made to have more events and activities that the early teens could participate in and benefit from. At the same time, other programs were offered for the older youth. Youth and young adults attended the weekend AMiCUS retreat for the second time and an increased participation was observed. Youths from two neighboring churches joined the youths of the church allowing for a nice mix of socialization and friendship.

The Adventist Youth (AY) Society was organized with the name chosen by the youth using the abbreviation for Kitchener-Waterloo, K-W (a.k.a. K "DUB" -Disciples United for Benevolence) with a new AY leader in his early 20's giving the youth ownership of their group. The previous AY leader was in her mid-late 30's. Many creative methods were used in the children's ministries such as KidZone-Children's Church, Preschool Zone, puppet ministry, and a large carpet and stools were purchased for Children's church for the children to sit on in order to make the experience more child-friendly and comfortable. A Vacation Bible School (VBS) was conducted for the first time in many years in spite of some challenges at the beginning to find volunteers for the program. Many children, especially the older ones; began to really appreciate all the attention they were receiving from the church. 


\section{Third Year of Intentional Ministry}

\section{September 2004-December 2004}

The NET 2004 satellite program was held at the church, but the youths and young adults showed little interest. During this period, more focus was given to nurturing and mentoring of early adolescents and older children. The Adventurer Club was started with some success, and the children showed enthusiasm about participating. A joint Christmas concert between three churches was held to help the local Family and Children's

Services. Many youth from the three neighboring churches participated in the preparation for the concert and also during the concert. The local radio station and the weatherman from the local TV station helped in promoting the concert. This resulted in increased community attendance and donations.

Also, the youths were encouraged to participate in ADRA (Adventist Development and Relief Agency) ingathering rally to help them learn more about the various ministries of the Seventh-day Adventist Church. This was intentionally done as a way of helping them to be proud of their own Adventist heritage and identity.

\section{January 2005-August 2005}

The AY Society leader served his second term, growing in the position and increasing in ability over the previous year. The youth leader and I developed a close supportive relationship. He attended church board meetings to give youth ministry reports and also brought youth agendas. Also, a new children's ministries' leader was appointed, she was an elementary school teacher, whose job description was to provide more child-friendly and child-oriented programs. The children's Sabbath School classes were joined as one class to properly train teachers and strengthen the structure of the 
children's ministries program. The children's ministries leader trained two other new teachers who made major progress in becoming proficient, efficient, and effective children's Sabbath School teachers.

A VBS was held for the second consecutive year with more participation from the children at the church and in the community. The program was successfully managed by volunteers without much input or assistance from my wife or myself, since we were heavily involved in the previous VBS. Following the VBS, I led a children's evangelistic series called, "Truth 4 Youth." At the end of the series, many children pledged to be baptized and they were affirmed for their decisions. Many parents appreciated the series because they observed major positive changes in their children's behavior in their homes. After many years absence, the Pathfinders club, for older children ages 10 and up and early adolescents, was launched with eight members attending.

Fourth Year of Intentional Ministry

\section{September 2005-December 2005}

The NET 2005 satellite program was conducted at the church, but still failed to attract the youths and young adults. A major development and improvement in children's ministries program was observed by parents and other visitors resulting in an increase in younger families attending the church. Parents also noticed a change in their children's behavior as they began showing the spirit of reverence and respect in the church. The children's Sabbath School division began to show more structure and organization within all the children's ministries divisions (Beginners, Kindergarten, Primary and Junior classes). KWSDAC was beginning to be known as a church with a strong children's program, and this allowed the church to be known to visitors and members of the 
neighboring churches. Many young couples with children started to attend the church and the number of children grew rapidly as the congregation witnessed more and more children present and at the front during the children's story time. The increased number of children excited the members, motivating them to support the children's ministries of the KWSDAC.

\section{Evaluation and Implementation-Mentoring and Discipleship}

Introduction

After four years of intentional ministry for the young people of the church, by laying the foundation for successful children's ministries and youth and young adult ministry, I felt that something more had to be done to encourage early adolescents to live a life of service and self-sacrifice which I strongly felt was and is crucial to not only keeping them in the church, but also to making them an integral part of Christian life and the church's ministries. I observed that the youth of the church were looking for fun events and activities that would entertain them, rather than looking for programs that would help them help others in need. I noticed that the spirit of self-serving was very much present in the lives of the adolescents. So continuing with on-going ministry events and activities, the need to mentor and disciple the adolescents to become Jesus' disciples was becoming an important mission of the church. The Church became more exciting and encouraging with relative success in children's ministries and youth and young adult ministry, and thus the church embarked on the new vision of intentionally mentoring and discipling adolescents to become missionaries, -- the true identity of Christians. 
Mentoring and discipleship strategies were to be kept in the simplest form, by having a mentor who was present for the adolescents, especially the early adolescents, to show what living Jesus Christ's self-renouncing and self-sacrificing love is all about. No grand mentoring and discipleship program was developed or instituted, but the simple truth of the mentoring and discipleship of Jesus Christ to His disciples in showing the life of self-renouncing and self-sacrificing love and presence was demonstrated. I chose to be more present with the youth hoping that by me reflecting and imitating the life of Jesus, they would be impacted to also accept and reveal Christ in their lives.

First Year of Intentional Mentoring and Discipleship-Year 2006

\section{Objectives for Early Adolescent Mentoring and Discipleship}

One of the definitions of mentoring with which I strongly agree is: "Mentoring is a lifelong relationship, in which a member helps a protégé reach her or his God-given potential" (Biehl, 1996, p. 19). What is this "God-given potential," as described in this definition? I believe it is to live a life as Christ lived here on earth. Aś I ponder on a definition of mentoring, I remember someone once said that "Youth ministry is ministry of presence." In fact, all ministries cannot be successful without the presence of the Holy Spirit working through a mentor or a pastoral care provider. I purposed that I would spend as much time as possible with the adolescents of the church, especially the early adolescents, by creating activities that I could participate in with them as I mentored them. In order to be relevant in their lives, I realized that my presence as their pastor and a mentor needed to be felt by them. I also realized that youth ministry cannot be an entertainment event, but an empowering experience to do God's work in spreading the 
Gospel. With these objectives in mind, the church decided to engage in youth missionary work, which we decided was sustainable and affordable. Part of the solution was to see our neighborhoods as mission fields, right here in North America, in our country, in our own province/state.

I developed a missionary project called Reach-Out Missionary Movement (ROMM), -- a movement that would allow youths and young adults to engage in annual, short-term mission trips to help their neighboring churches and their communities.

\section{Continuing Active Youth and Young Adult Ministry.}

Eight youth days were scheduled for the year, and the youth and late adolescents participated in all the parts of the worship service. At the end of the year, a ninth youth day was held. Many youths from the local church and from neighboring communities participated. Speakers were invited to address many youth related topics such as: Christian dating, Christian relationships, Christian lifestyle issues, young adult spirituality, etc. These speakers and their presentations were well received and appreciated. I continued to build a closer relationship with the children and the youths of the church and continued to chair the CYMAC with a deeper understanding of the needs of the children and youths of the church. Increased communication between the church board and the CYMAC allowed the children's and youth ministry to receive needed resources, including monetary funding, enhancing the effectiveness of both ministries. During the monthly church board meeting, reports were given from the youth leaders and children's ministries leaders allowing the church to know the progress and challenges of the children's ministries and youth ministry. 
It was observed that the children's ministries and youth ministry were doing relatively well and the youth day Sabbaths were attracting many other youths and young adults from other churches. New dynamics were developing because some new youths/young adults coming into the church demonstrated both strong will and initiative. At this time also, Friday night youth vespers meetings commenced, using more interactive Bible study and small group discussions, however, this did not work too well at the start. Much thought was given and prayers offered to see how the missionary spirit could be instilled in the minds and hearts of the adolescents as preparation was made to launch an annual mission project.

\section{Second Year of Intentional Mentoring and Discipleship-Year 2007}

\section{Major Challenge Faced-Cultural Conflict and Clash}

The matter of music became a major issue and came to the forefront during a Youth-day Sabbath. The church took offence and took a stand against the kind of music that was being played during the divine worship service. The music offended many members, including some youth. Unfortunately, the youth who was responsible for this "offensive" music was not a member of the church, but a new attendee who was refusing to adhere to the instructions of the church leadership. His refusal to respect the recommendations of the church board and his continuing negative influence on other youths/young adults, with his strong views, created major challenges for the church. As a result, a couple of young adults showed distrust and disapproval of the decisions of the church board. 
This incident caused a division among the youths/young adults, separating those who sided with the youths in question and those who supported the church board's decisions and instructions. The majority of the displeased youths were young adults who were not attending the church regularly and thus, did not have the opportunity to be mentored. However, all of the AY Society leadership supported the decision of the church board and sought guidance and counsel from me, resulting in a stronger bond between us. The youth ministry programs of the church were successful, and attracted many youth/young adults, but unfortunately, some came into the church with a personal agenda to change the way things had previously been done. This added to the conflict, and consequently, some of them started attending less frequently. Fortunately, most of these youth/young adults returned and accepted the spiritual mentoring of the church family.

\section{Cultivating Missionary Spirit and the Missionaries}

A "missionary spirit" vision was cast and a mission trip plan was set by me and the youths who were excited to participate in missionary work. Many youth, including a handful of early adolescents, 13 years and older, who had been mentored and nurtured for the past three to four years, along with other teens and three other young adults in their 20 's, joined the missionary training. They spent three full days in missionary training, learning Adventist beliefs and acquiring skills to conduct a VBS in the mission field. Missionaries who had been trained during the missionary training sessions and also during the entire week of KWSDAC's VBS program went to Six Nations, an aboriginal people's reservation, as the ROMM (Reach-Out Missionary Movement) missionaries. 
These were the first batch of youth missionaries sent out by the church. They went through a week-long life-changing experience with: hosting morning and evening devotional worship, conducting a VBS program, participating in service projects, and witnessing how children changed before their eyes. At the end of the mission trip, six youths, between the ages of 13-17, who had been mentored and nurtured for the past three to four years, got baptized. The church experienced a major synergy effect as the youth ROMM missionaries shared their missionary experience with the entire church.

\section{Children's Evangelistic Series}

The children's evangelistic series called, "Truth 4 Youth" was held once again for the second time. Children once again pledged to be baptized at the end of the series. Many parents appreciated the series because they observed major positive changes in their children's behavior. Even many older children pledged to be baptized, however their baptism was delayed to allow them to continue to be mentored and nurtured. This was to ensure that the children did not get baptized out of impulse, but rather, as a result of their long-term conviction and commitment.

The first youth mission trip impacted the church in a special way as the youth missionaries continued to inspire and influence other members, especially their peers and the older children who were excited that one day they too would also get a chance to go on a mission trip as youth missionaries. The church was successful in creating a positive peer influence that motivated others to volunteer to go as youth missionaries in the future.

The children's ministry was progressing very well with a full-blown children's ministries program and the frequent participation of the children in the adult Sabbath School program. A children's choir was established, and called the K-W Adventist 
Junior Choir. It performed its major concert at the end of the year, producing some very excited and proud children. Many of the young mentees were now of age to join the Pathfinder's Club. The Club had its first investiture and induction service with over 20 full-pledged Pathfinders and 5 instructors.

At this time, an AMiCUS campus ministry chapter at the University of Waterloo was initiated and named, "The Blue Rock Christian Fellowship," though its name was later changed to "Waterloo Adventist Christians Association (WACA)." This group met regularly every Friday afternoon at the university campus student center with nonAdventist students attending from time to time. All the youth missionaries and other youth, approximately 15 youths/young adults in total, attended the midweek Wednesday night Bible studies and prayer meeting. They studied the book of Genesis and learned about Abraham, Isaac, Jacob, and Joseph and their individual faith experiences.

The Church's Youth days continued to be dynamic, especially when the youth missionaries shared their experiences. They continued to be a positive influence/example to other youth, especially those who were younger. They created a new culture by motivating the young people into believing that being a missionary was a "cool thing" and a privilege for the youth of the church. A new tradition for the youth was established and many now wanted to become a part of the ROMM missionaries. Instilling in the youth the missionary spirit was giving positive motivation to them as they built their Christian identity. The ROMM missionaries' motto is: "Who do we believe? Jesus! I am a missionary! The LORD calls me! I can do it! Yes, we can! Once missionary, always missionary!" The church now had a full-blown youth ministry with two associate 
leaders and many youth AY Society officers. More and more youth were getting involved and they were organizing events and activities under pastoral guidance.

Third Year of Intentional Mentoring and Discipleship-Year 2008

\section{Mentoring and Discipleship for Evangelism and Witnessing}

This began the first of a two-year evangelism emphasis. The church continued to grow and more new non-Adventists visited. Two were baptized and another awaited baptism. The children's Sabbath school department was also growing, with the divisions reaching maximum capacity and needing an additional Primary division class. The success of the children's ministry was in part, due to regular communication with parents and the reciprocal parental support. The AY Society leader who had been appointed for the year 2006 served two full terms ( 2 years) and was asked to serve another two years (2008 \& 2009). She was mentored and then began to mentor many other youth along with four additional associate and assistant K-W (DUB) AY Society leaders.

The youth missionaries trained for the second year with new missionary candidates and were excited to go to the mission field at Six Nations. During the mission trip, the missionaries painted the local Adventist church, conducted VBS for the children, and visited another Adventist church for a Sabbath mission presentation. They returned home fired up and more dedicated to God's service and with a burning "missionary spirit." A couple of youths who joined the missionaries were known as "mischievous," but came back from the mission trip changed. Once back home, the missionaries conducted another successful VBS at their local church with very little assistance from adults. This was the first VBS the youth ever sponsored. 
The third children's evangelistic series "Truth 4 Youth" was conducted, and once again, all the children pledged to be baptized. They continued to receive mentoring and nurturing with the specific intent to instill in them a Christian identity by building good habits. Another church evangelistic series was conducted and this had more attendees than ever before, with many deciding to be baptized. In addition, the Pathfinders Club was stronger than ever with 25 full pledged members and seven instructors. It became the largest in the region, winning awards and making the children proud of their achievements. The children's K-W Adventist Junior Choir continued going strong, meeting regularly to prepare for the second year-end concert.

\section{Peer Mentoring-FNL (Friday Night Live)}

Friday night youth vespers met regularly every Friday night in addition to midweek Wednesday Bible studies and prayer meetings. The youth Friday night vespers meeting was named "Friday Night Live (noun)." Here the youth discussed challenges they faced in their culture and other issues and topics that were relevant to them. The youth leaders, who organized the Friday Night Live (FNL) which was mainly attended by the older teens, decided to dedicate one Friday night youth vespers meeting each month to the early teens (10-15), and called it "Friday Night Lead" (led by youth to lead early teens) as a way to "give back" in honor of how they were led as early teens. They also agreed to host a youth/young adult Friday night vespers service for the older youth/young adults (college/university students and up) and call it "Friday Night Live (verb)." This vesper program provided specific mentoring from the pastor. They decided to call the other Friday night youth vesper services "Friday Night Light" as they continued to address and discuss current youth issues and concerns as they learned to be "the light of 
the world." During the FNLs, youths were engaging in mentoring and discipleship relationships, either with their pastor (me) and/or with other older youth/youths or youth leaders.

\section{Empowered to Serve and Evangelize}

The youth/young adults also planned the entire youth evangelistic series, reaching out to other youth/young adults as they built dynamic youth programs, creating a synergy effect among the youth. Finally, the youth/young adults continued to play major roles in the church, participating in many events and activities.

Fourth Year of Intentional Mentoring and Discipleship_-Year 2009

\section{Instilling the Christian Identity-Living Self-Sacrificing Love}

When we first went to Six Nations, we had a few days of training where they were taught the missionary spirit which is to live a life of self-sacrificing and selfrenouncing love. The stories of Samuel and Isaiah were used to teach how we ought to respond to the call for service. Of the children who were younger than 13 , two preadolescents wanted to join the mission trip to Six Nations, so their parents took their vacation time to come and spend the entire week with the group so that their children could participate in the mission trip. Those two preadolescents joined every mission trip since 2007 and their mission experiences helped them to grow more spiritually mature.

\section{ROCMM-Reach-Out \& Care Missionary Movement}

The name of the youth missionary group was changed from ROMM (Reach-Out Missionary Movement) to ROCMM (Rèach-Out and Care Missionary Movement) 
emphasizing the importance of reaching out to others in need and caring for their needs. The summer was utilized to provide many activities that would bring adolescents closer to their peer mentors and to the other mentors. Programs such as FNL youth vespers, the three-day missionary training, the ROCMM mission trip and AMiCUS Campus Ministry, all provided opportunities for the spiritual growth of the youth.

\section{Building Partnership with Other Mentors}

The Reach Out \& Care Missionary Movement (ROCMM) established a long-term missionary partnership with the pastor of the Harriston Seventh-day Adventist Church. It was a unique and special experience, since for the next four years, whichever district in which this pastor ministered, the ROCMM missionaries would go there to conduct VBS, church evangelistic series, youth revival series, community service, etc. This partnership was very important as the ROCMM missionaries found another mentor to care for them. Friendships built between the ROCMM missionaries and the hosting churches' youths positively influenced the youth of participating churches as they peer mentored each other. Parents of the ROCMM missionaries also became mentors to the youth of the church as their presence, care and love were felt by the adolescents.

\section{Essence of Early Adolescent Mentoring and Discipleship}

Much time was spent in emphasizing the importance of exercising the missionary spirit which is to live a life of self-renouncing and self-sacrificing love, reminding the adolescents that to follow Jesus means to live a life of self-sacrificing love as Jesus did. In order to teach them a life of self-renouncing and self-sacrificing love, early adolescents 
were given opportunities to engage in service projects both inside the church and also outside the church. Christian service is the key to living the missionary spirit.

Fifth Year of Intentional Mentoring and Discipleship-Year 2010

\section{Identity Installation and Preservation}

Three days of ROCMM missionary training was held again in preparation for another mission trip which now became a tradition for the church. The early adolescents waited anxiously for their $13^{\text {th }}$ birthday since they know they will be given that coveted chance to join the youth ROCMM mission trip. The ROCMM mission trip to the Harriston Seventh-day Adventist Church for the second year developed a stronger bond and partnership between the two churches as the pastors and the members, especially the youth, worked together as a team.

\section{Pathfinders and Adventist Identity}

The KWSDAC's Pathfinder Club was named the K-W HOPE Pathfinder Club. "HOPE" is an acronym for "Helping Others Prepare for Eternity." The K-W HOPE Pathfinders with their support staff and the pastor attended the Pathfinders' Oshkosh International Camporee at Oshkosh (Wisconsin, United States) where they engaged in learning their Christian identity and standing up for what they believed. This experience positively affected the pathfinders. The motto for the camporee was "Courage to Stand." They were reminded of their true identity as children of God by listening to the story of Esther and of the importance of standing up for what they believed. 


\section{Positive Peer Influence}

During the ROCMM Harriston mission trip, a close bond was built by the hosting pastor and the youth of his church since this was the second year for the youth of the two churches to join together in reaching out to the community. During the mission trip, each morning they conducted VBS, and in the evening, one of the youth leaders of the church, a university student, conducted a revival series for the church. As ROCMM missionaries returned from their mission trips, those who were not baptized before decided to be baptized.

\section{Practicing Jesus Christ's Self-Renouncing and Self-Sacrificing Love}

As the adolescents gave their lives to the Lord, many others were encouraged to follow in their steps and this positive peer influence encouraged the other youths of the church to become more faithful and dedicated in serving God and others. The parents of the church began to notice the positive impact this intentional mentoring and discipleship had on the children. They encouraged their children to continue to attend the FNL vespers and participate in the ROCMM mission trips. At this point, when adolescents were asked what is their mission as Christians, they answered by saying that "it is to practice Jesus Christ's self-sacrificing love."

The youth of the KWSDAC were encouraged to continue practicing the love of Jesus Christ by engaging in feeding the homeless, visiting nursing homes and retirement homes, visiting senior members of the church, and also cleaning the community to which they were sent as missionaries. The importance of Christian service was repeatedly emphasized during youth programs, and the church endeavored to create events and 
activities that would allow the missionary spirit to be practiced and exercised. Instilling the missionary spirit into the hearts and minds of the youth convinced them that they did not come to church to be entertained or served, but to serve and care for the needs of others instead of their own.

Sixth Year of Intentional Mentoring and Discipleship-Year 2011

\section{Living the Missionary Spirit}

As the ROCMM mission trips were repeated every year since 2007, the youths of the KWSDAC now looked forward to the annual mission trip. Now, new locations were considered as potential mission fields, and renewed excitement and enthusiasm was evident. During the mission trip, the missionaries were housed in the basement of the "receiving" church. Sometimes they were very uncomfortable and inconvenienced, but the pastor and the youth leaders reminded them of their identity as missionaries and encouraged them to find ways to overcome the hardships. Some of the teens had never left their homes before and both they and their parents were apprehensive about the experience, however, leaving for God's mission work brought more rewarding experiences for both the adolescents and their parents. Some ROCMM missionaries attended every single one of the mission trips and became sources of inspiration and encouragement to others.

\section{Youth Missionaries Being Mentored and Mentoring Other Youths}

It was observed that after five years of mission trips and FNL vespers that constantly reminded the youth of the KWSDAC of the importance of the missionary spirit, many youths were stepping up to become peer-mentors to other youths. They 
began leading out at youth ministry activities and other youth social gatherings, and being positive role models to other younger youth. I developed a close relationship with the youth leaders and continued to mentor and disciple them. It became evident that the youth were looking for authentic mentors who could teach them how to live the Christian life that Jesus lived.

\section{Keeping the Missionary Spirit Afresh and} Alive

Although the missionary spirit was very much alive during the mission trip, it became a challenge to keep it alive in the time following the trips. Also, those youths who were not able to participate in the missionary trips, who were now older, did not have the same conviction for mission work as those who did attend the mission trips. However, even amidst the challenges, both the parents and the youths themselves noticed that the mentoring by the pastor was keeping their children more active and involved in the church. This evidence encouraged them to stay in the program.

Project/Seventh Year of Intentional Mentoring and Discipleship-Year 2012

\section{Objectives for the Short-term Project}

The objectives of the short-term project are as follows: (a) Increase the presence of the pastor as a mentor as much as possible, (b) Help the parents of the early adolescents understand the importance of early mentoring and discipleship and invite them to become partners in mentoring and discipling them, (c) Introduce the true identity of Christians which is the missionary spirit to early adolescents, to allow them to join the ROCMM mission trip, (d) Allow the pastor's mentoring and discipleship opportunities to increase by having him lead FNL group discussions, the Sabbath School lesson study and 
service projects, and (e) To become first a true follower or disciple of Christ as the mentor in order to be an example to the early adolescents.

\section{Rationale and Preparation for Early Adolescent Mentoring and Discipleship}

Over almost a decade, it was truly inspiring to witness the children and preadolescents who participated in the past six years of intentional mentoring and discipleship grow to become young adults actively contributing in the church. Therefore, a plan was established to begin another mentoring program with a new group of early adolescents. The teens were identified, their parents contacted and with the parents' permission and the permission of the early adolescents, they were engaged in intentional mentoring and discipleship for the period of seven months. They were encouraged to attend the FNL vespers meetings, Sabbath School lesson studies, and service projects for caring and helping people in need.

\section{Pastor the Mentor}

As previously indicated, the approach taken was for me to create a mentor-mentee relationship with the youth, by serving as their primary mentor, -- spending time with them in building friendships and fellowship. I chose to lead out FNL vespers group discussions, junior and early teen Sabbath school classes, Sabbath afternoon activities, and service projects both in caring for the senior members of the church and helping the people in need in the community. In addition, I hosted monthly social gatherings and movie nights at my house. The movies were carefully chosen to teach the youths about their Christian identity. 
I hoped that through a joint effort and partnership, that the pastor, youth and early adolescents could experience living Jesus' selfless self-sacrificing life. As they were reminded of the missionary spirit of going where God wants us to go, and doing what God wants us to do, often resulting in ultimate sacrifice on our part, they learned the Christian identity of living the life that Jesus lived.

\section{Project Implementation}

At the beginning of 2012, I met with the parents of the adolescents and the teens themselves to explain the requirements of the project, at which time, they both signed the permission forms and agreed to the project. They began by visiting the senior citizens of the church, discussing teen topics during FNL vespers and studying from both the Junior Sabbath School lesson and the Early Teen's Sabbath School lesson. Their Sabbath School class was composed of a mixture of youths, some were exhibiting adolescent behavior, and some were still exhibiting child-like behavior. Using both lessons in this class allowed for a discussion that encompassed all levels of maturity.

\section{Follow Me Adventist Movement Facebook Group}

The new batch of mentees were added to the exclusive, invitation only, Facebook group where they were encouraged to express their faith and share inspiring quotes. The Facebook group was created for them, but their parents were also added to ensure their children's activities in cyberspace were monitored. Some parents who were considered "cool" by the early adolescents also posted inspiring quotes and Bible verses, too. The Facebook group served as a forum where they were encouraged to show their Christian identity and also learn from the faith expressions of other youths. The Follow Me 
Adventist Movement Facebook group was also used to keep the adolescents and their parents informed of events and activities.

\section{Follow Me Silent Service Flash Mob}

These early adolescents joined me for the Follow Me Silent Service Flash Mob (FMSSFM), which was held on Father's Day at the Toronto City Hall. On the day of the

FMSSFM, they, along with their parents, met at Toronto City Hall dressed in t-shirts that read "Follow Me Adventist Movement" (see Appendix K). In total silence, they picked up garbage and litter for half an hour. During this silent service flash mob, people commended them and their families for the community service they were doing. An official from city hall came down to personally thank them for their service. The adolescents were encouraged by the positive attention they received while they were showing their true Christian identity.

\section{ROCMM Mission Trip to Lindsay}

After three days of missionary training, twelve early adolescents, ages 10 to 15 , joined the ROCMM mission trip to Lindsay. During the mission trip, they conducted a VBS program and led VBS stations with the older youths. At first, some of the teens were shy and apprehensive, but soon they overcame their fear and were leading and working with other children whom they had never met before. Friendships were built between the ROCMM missionaries and the youths of the hosting church. A revival series was held, and the ROCMM missionaries participated in song service, special music, scripture reading and prayer, as well as other tasks during the series. The hosting church was not only impressed with the ROCMM youth missionaries, but also very much 
appreciated their inspiring efforts and their missionary spirit. The ROCMM mission trip to Lindsay left a strong impression in the minds of the early adolescents.

\section{“Once a Missionary, Always a Missionary!"}

After returning from the mission trip, the early adolescents continued to do missionary work by visiting nursing homes, becoming involved in community service projects, and caring for the seniors of the church. In every church that the early adolescents and youth missionaries visited, they befriended the youth of the hosting church and developed friendships. The youth leaders who had gone through six years of intentional mentoring were given an opportunity to lead youth Bible study group discussions and youth social nights. Some who were early adolescents at the first youth mission trip of 2007 were now university students, and their leadership and participation in projects were an inspiration to those around them. Experiencing six years of missionary training and six mission trips instilled in them the true identity of a Christian, to be a missionary.

\section{Mentor's Presence}

During the seven-year long-term project, I tried my best to attend all the youth events and activities, such as FNL youth vespers services, youth social gatherings, all the mission trips, each VBS, leading the "Truth 4 Youth" children's evangelistic series, and many other activities in order to be present as a pastor mentor. It was very challenging and difficult at times, but many youths welcomed their pastor's involvement, and many frequently opened up to discuss issues that were affecting them. This did not happen overnight, but through years of intentional mentoring. 
During the short-term project, a period of seven months, I intentionally spent as much time as possible with the early adolescents. I attended youth events, went out for youth dinners, attended FNL-Friday Night Live youth vespers services, taught Sabbath School lessons, had social nights once every month, and invited them to my house. I joined them on the ROCMM mission trip to Lindsay (Ontario, Canada), conducted the missionary training, was present for the VBS, and conducted morning and evening devotional messages during the mission trip, as well as participating in community services with the ROCMM youth missionaries. I became their friend and mentor who they could "play around" with, but also take seriously when they were taught and mentored.

\section{Summary}

It is truly harder to become a mentor, rather than a leader, but when one is a mentor, one will impact the lives of others in fulfilling their God given potential. It is more rewarding to be a mentor than to be a preacher or an administrator as one's influence will change someone's life completely and utterly for the better. 


\section{CHAPTER 5}

\section{EVALUATION AND OUTCOMES}

\section{Introduction}

The purpose of this project was to develop and implement a mentoring and discipleship program/process for early adolescents of the Kitchener-Waterloo Seventhday Adventist Church (KWSDAC) and evaluate whether intentional mentoring and discipleship by a mentor would increase the level of involvement in service by the early adolescents of KWSDAC. Early adolescents of the church were encouraged to participate in church youth ministry programs and activities during the project, and they were involved in group discussions intended for group mentoring and discipleship. They were encouraged to take journals to write down their experiences and answer questions given to them during youth ministry programs and activities intended for mentoring and discipleship. In this chapter, qualitative research results will be described and analyzed to evaluate the outcome of the project.

\section{Adolescent Choices and Decisions}

During one of the FNL (Friday Night Live) youth vespers service, 18 adolescents were divided into three groups of six according to their age. Two 15 -year-old early adolescents joined the middle adolescents group in order to have six adolescents in each of the three groups. There was: (a) an early adolescents group with those between the 
ages of 10 to 14, (b) an early adolescents and middle adolescents group of those between the ages of 15 to 18 with two 15-year-old early adolescents joining the group, and (c) a late adolescents group with those between the ages of 19 to mid 20s. They were then asked the following question, "What are some choices and decisions you had/have to make?"

\section{Early Adolescent Choices and Decisions}

According to the early adolescents group, they said that they were faced with the following choices and decisions: "high school, peers/friends, drugs, clothes/hair, relationships/sex, parties, sites to view/internet, jobs, peer pressure, money, responsibility, school teams, boyfriends/girlfriends, hygiene, alcohol/smoking, things you buy, cell phones, respecting parents, school work, modesty, involvement '@' [at] school, food, popularity, electives, how you act towards people, how you treat your body, and God/religion" (see Appendix B).

\section{Early and Middle Adolescents Choices and Decisions}

Early adolescents 15 years of age and middle adolescents $17-18$ years of age gave the following answers as choices and decisions they had/have to make: "What classes should I take? Saying no to drugs. Should I eat? Should I smoke? Saying no to b-day [birthday] parties on Sabbath. Saying no to parties. Should I hang out with certain type of 'ppl' [people]? Should I go to class? TV, Type of entertainment. Obeying parents. Defining relationship with Jesus. Inappropriate language. Should I buy this? Should I be sexually active? Peer-pressure (following trends). Evolution argument. Relationships. Should I shave? What I can and cannot do on the Sabbath? Driving. 
University. Judging people. Rebelling. Should I move out? And Reduce, Reuse, Recycle" (see Appendix B).

\section{Late Adolescents Choices and Decisions}

Late adolescents between the ages 19 to mid 20s answered that the group faced different choices and decisions at each of the following ages: (a) while they were "10 to 14-Sports or music lessons? Which martial arts am I going to take? Who will my friends be? What will my hobby be? Whether or not to attend worship service [and whether to] sleep in church?" (b) while they were "15 to 18-Which university/college will I go to? Will I go to work force? What will be my major? Girlfriend/boyfriend choice. Premarital sex. Should I follow my parents' religion?" and (c) after the age of 19, "To drink or not to drink? Drug/substance abuse. Graduate school or work after university? Or a professional school? Looking for a future spouse. Choosing a responsibility/role in the church. Choice of political views. And Building professional network contacts" (see Appendix B).

\section{Group Observation}

It was quite surprising for the adolescents who participated in the group survey and the researcher [me] to discover that almost all the lifestyle choices and decisions older adolescents had/have to make, except for professional career and academic advancement, even early adolescents had/have to make those same difficult choices at an earlier age. In fact, many choices/decisions that some think are the choices/decisions of "older people," contrary to their misperception, early adolescents are faced with these 
same decisions, and are required to make those choices/decisions which have serious consequences that can alter an adolescent's life so drastically, profoundly, and severely.

Adolescents who participated in the survey observed and noted that early adolescents today are dealing with "more mature" or "more adult-like" lifestyle issues much earlier than when the older adolescents were first exposed to them. The adults who were there were very surprised by the results of the survey and later spoke to the researcher [me] of how alarmed they were by the answers given by early adolescents. They were shocked to learn that those choices/decisions are what our early adolescents are faced with in their everyday living at such an early age.

\section{Early Adolescent Choices and Decisions}

During another FNL (Friday Night Live youth vespers service) youth group mentoring and discipleship session, 10 early adolescents between the ages 10 to 14 (15 year old adolescent was not present) along with older adolescents were asked to write down the three most difficult choices/decisions they had to make recently. Their answers revealed that both early adolescent girls and early adolescent boys are becoming more socially aware and recognize the importance of choosing and having their friends. However, there were some notable differences between the answers given by early adolescent girls and early adolescent boys.

\section{Early Adolescent Boys Choices/Decisions}

One 10-year-old early adolescent boy answered that his difficult choices are, "What to wear, friends, and what to do?" while another 11-year-old early adolescent boy answered that "carrots, salad, and dogs" are his difficult choices. A different 11-year-old 
early adolescent boy answered that the following are his difficult choices/decisions: "What friends this week, what to buy, and whether to get Minecraft [computer game]" (see Appendix C). It was observed that some answers were very childish, but as children transitioned into adolescence, their answers reflected their increased social awareness.

\section{Early Adolescent Girls Choices/Decisions}

A 12-year-old girl gave her three most difficult choices/decisions that she had to make recently: "If I should buy extension (hair). Honesty with your [her] parents. If I should buy a Blackberry." One 13-year-old early adolescent girl said, "Not to steal, not curse, and not to disable my ' $\mathrm{fb}$ ' [Facebook]" are the top three most difficult choices for her to make. Another 13-year-old girl answered that "drugs, what to wear (modestly), and friends" are the three most difficult choices/decisions for her. Yet another 13-yearold adolescent girl answered the following as her most difficult choices/decisions:

"Should I care about what I look like? What to wear? What to buy?" The oldest of the group, one 14-year-old early adolescent girl said that "getting twitter, what high school to go to, and wearing leggings" are her tough choices/decisions (see Appendix D).

\section{Secrets of Adolescents and Perception of Early Adolescents' Parents}

During the project, adolescents were asked, "How much do your parents know you?" It was interesting to observe that there was a notable difference between what adolescents thought about how much their parents know them and how much parents believed they know of their adolescent children. 


\section{Early Adolescents' Responses}

Early adolescents' responses showed that while some of their parents knew them completely, other early adolescents parents knew them less. Two early adolescent boys, 11 and 12 years old, and one 13-year-old early adolescent girl answered that their parents know them $100 \%$. While the three early adolescents felt that their parents know everything about them, other early adolescents were divided in answering the question how much their parents know them. Another 11-year-old early adolescent boy answered that his parents (or parent) know $89 \%$ of him, another 12-year-old early adolescent girl answered that her parents (or parent) know $96 \%$ of her, and another 14-year-old early adolescent girl answered that her parents (or parent) know $85 \%$ of her. For other early adolescents, they perceived that their parents (or parent) know them less than other parents (or parent) know their children. Two 13-year-old early adolescent girls answered that their parents know $65 \%$ and $60 \%$ of them relatively. Another 10 -year-old early adolescent boy answered that his parents (or parent) know $53 \%$ of him and another 12 year-old early adolescent girl wrote that her parents know only $45 \%$ of her. This 12 -yearold early adolescent girl also answered that "Honesty with your [her] parents" is one of the three most difficult decisions she had to make (see Appendix $C-D$ ).

\section{Perception of Early Adolescents' Parents}

During the early adolescents' and parents' Sabbath dinner fellowship gathering, the parents answered the following question, "How much do you know your children?" This question was asked to compare the perceptions of both the parents and their early adolescents regarding their knowledge of their early adolescents. Nine early adolescents' parents answered and among them, one early adolescent's parent said that he/she knew 
his/her daughter $90 \%$. Four early adolescents' parents answered that they knew their children $80 \%$. Three early adolescents' parents answered that they knew their children $70 \%$ and one early adolescent's parent answered that he/she knew his/her early adolescent son $60 \%$ (see Appendix E-G). Parents seem to want to believe that they have a good idea regarding what their early adolescent children are doing and what they are experiencing as early adolescents. However, this may not always be the case.

\section{Summary}

While all the early adolescents' parents, except two, thought that they all knew their early adolescent children between 70-80\%, their early adolescent children's answers differ greatly, between $45-100 \%$. This was a significant finding which proved a point to the parents that not all the parents of early adolescents knew their children as well as they thought they did. The important question asked at the end of the meeting among the parents was, "If what our early adolescent children think and what we perceive are different, and if our children think that we don't know them, what are those secrets that they are hiding from us that we should be concerned about?"

This is the reality of raising early adolescents. Some think that they know their early adolescents well, and that may be true, but in many cases, parents of early adolescents don't know their children as well as they think. How can parents help their early adolescent children, if they are so naïve to think that they know their children well and they don't need help from other mentors? Secrets of early adolescents and misperceptions of parents need to be recognized and addressed in order for there to be effective parenting or mentoring relationships that can help early adolescents grow into healthy adults in all aspects of their lives. 


\section{Challenges of Mentoring/Parenting Early Adolescent}

Early adolescents' parents experience many challenges with their children every day. That became apparent during the project when the parents expressed their concerns about the difficulties they were facing in dealing with their early adolescent children. In this section, these challenges will be described and discussed.

Parents' Perspectives of Early Adolescents' Choices and Decisions

During the project, it was observed that the parents of early adolescents of the KWSDAC were well informed as a group of the choices and decisions their early adolescent children were faced with. The following is the summary of the answers given by the early adolescents' parents about the choices and decisions their children are making: "Drugs, the opposite sex, fear of high school, smoking, the internet; What high school will I [my child] go to, when and who will I [my child] date, dealing with peer pressure, clothing styles whether to dress liberal or conservative; To choose from between right from wrong associated with peer pressure; Choice of friends, music to listen to, continue to trust God and build their faith in God, career to choose; Peer pressure, relationship with other sex, religious belief (e.g. Halloween); The way they clothe themselves, challenges of changing hormones; Choice of standing alone and being different (by not participating in [non-religious] Sabbath hours activities); Social media, school work, friends, food; and Afraid to the dark and be alone, and violence in the family" (see Appendix E-G). 
Parents' Challenges With Early Adolescent Behaviors

During the project, parents of early adolescents described the challenges they had with their early adolescent children. The following are the challenges the parents claimed they faced with their early adolescents: "Back talking, disrespect, constant fighting with sister, potty mouth ‘@' [at] school, disobedience; Strong willed, but[t]s heads with parents; Challenges [with] obedience, to read the Word of God, belonging [to] school \& church activities; Building their faith \& trust in God, encourage personal devotional time; Being more responsible, not being challenged (thinks less of self always takes easy way out); Staying up late - the child reads in bed oblivious of the time, bickering $\mathrm{w} /$ [with] younger sibling, too bos[s]y w/ [with] younger sibling, doesn't want to be told the obvious, trying to test their limit (talking back to parents sometimes); Child not feeling able to talk about hurt feelings rather keep to themselves, not obeying parents decisions, wanting to make own [decisions]; [dis]obedience, food choices, clothes/dress choices; and to study at college/university (personal challenge), don't get marry too young, or get girlfriend" (see Appendix E-G).

\section{Choices and Decisions for Early Adolescents' Spiritual Growth}

Early adolescents were asked to give answers to the following two questions: "What are some things that you can do to help you grow spiritually?" and "What have you done in the past that helped you grow spiritually?" The following are their answers.

\section{Positive Choices/Decisions for Early Adolescents' Spirituality}

The following are the answers early adolescents gave which they believe can help them grow spirituality: "Reading Bible, prayer, trying to not sin; The Bible, 'chars' 
[chores?], 'moon'; Having my own personal devotion every morning and evening; Daily devotion, prayer, trying not to sin; By reading the Bible with the pastor; Bible, church, healthy relationship with God, pastor; Bible, prayer, worship; Encouraging friends, daily prayer \& meditation, personal devotion, opportunity; Applying the lesson [quarterly] to my life, praying more; and The Bible, Christian music" (see Appendix C-D).

Choices/Decisions Positively Impacted Early Adolescents' Spirituality

The following answers were given by early adolescents when asked, "What did you do that helped you grow spiritually?" Early adolescents answered that "[Being] baptized; Have a Bible; [attending] baptismal class at church; Having personal worship!!! Me [she] getting a Bible; Having personal worship; Deciding to read a person[al] devotional book \& applying the lessons; and Having worship in da [the] morning" were the things they did that helped them grow spiritually (see Appendix $C-D$ ).

\section{An Observation}

It was observed that the answers of early adolescents clearly exhibited the characteristics of early adolescence and early adolescent behaviors. Some answers were very simple as other answers were more thought-out, typical of children transitioning into early adolescence as they learn to do abstract thinking, as their cognitive ability develops, and as they go through pubertal change accompanied with hormonal changes and continuous brain development.

\section{Intentional Early Adolescent Ministry That Made a Difference}

At the end of the intentional early adolescent mentoring and discipleship, both early adolescents and their parents expressed their experiences and observations. 


\section{Parents' Evaluations and Observations}

Even though the answers of early adolescents were simple and less complicated, their parents noticed how the intentional mentoring the youth ministry provided for them seemed to have positively impacted and affected their children. The parents have also been intentional in their partnership with me to help their children grow spiritually and they have observed significant changes in them.

The parents answered that the following helped their early adolescent children grow spiritually: "Daily devotion, family praise, worship; FNL (Friday Night Live youth vespers service), older brother[s] \& sisters in the church, role models (mentors); mission trip, inclusion within the church circle; going on mission trip-the first one for my child, spiritual experience was excellent; Pathfinders, mission trip, being more active in the church; Every summer mission trip, VBS / Friday Night Live [FNL], evangelistic series for children; Continued to read Bible daily; Mission trips, Pathfinder Club, Sabbath School, VBS, outreach programs of church, family worship, girls night out; and Pathfinder[s'] Camporee, and [child's] wish to growth [grow] in spiritual life, to learn some sports such as soccer, volleyball, etc." (see Appendix E-G).

Early Adolescents' Responses/Reflections and Observations

Fifteen early adolescents between the ages 10 to 15 responded to the youth questionnaire (see Appendix I). Eleven early adolescents participated in at least one of the intentional mentoring and discipleship program/process activities offered, including the mission trip, during the short-term mentoring project. Four early adolescents were not able to join the mission trip which was a big part of the short-term mentoring and discipleship project. 


\section{Reflection Questions}

At the end of the short-term mentoring and discipleship project for early adolescents, they were given the following nine questions to reflect on: (a) How close did you feel to God at the beginning of 2012 ? [0 to 10 , "0" being the weakest and " 10 " being the strongest]; (b) How close do you feel to God now? [0 to 10]; (c) If you feel more close to God now than before, what helped you (or what did you do in 2012 to feel closer to God more than before?; (d) Please name a couple of church activities that you participated in 2012 that may have helped you feel close to God (or grow spiritually)?;

(e) If you don't feel close to God, why do you feel that way? Name some reasons why;

(f) What can the church do to help you feel close to God (or grow spiritually)?; (g) Do you have someone who you can talk to about your problems? If yes, who is it or who are they? If not, who do you wish that you can talk to?; (h) Who would you go to other than your parents for help encouragement, answers to your questions, guidance and support?; (i) Is there someone at the church who you feel close to or you feel that you can talk to about your problems? If yes, who is it or who are they? (see Appendix I).

\section{Early Adolescents' Responses and Reflections}

Secrecy and Privacy of Early Adolescents

As early adolescents were giving their responses and reflections to the questions, it was observed that they were very careful not to reveal their own identities. They didn't want to be identified and wanted to answer the questions in secrecy. They didn't want their peers or the researcher [me] to see their answers while they were giving them. I could sense that they wanted to answer the questions without having to reveal who they are. After answering the youth questionnaire, early adolescents quickly stacked them 
under the pile not wanting others to see their answers. Honoring and respecting their wishes and sentiments, their responses and reflections will be converged to conceal their identities in order to ensure anonymity.

Early Adolescents' Sense of Closeness to God, Before and After the Short-Term Project

Out of the 15 early adolescents who answered the youth questionnaire, 9 responded by saying that they feel closer to God now than the beginning of 2012. Three answered that there are no changes to their perceived closeness to God and the last three answered that they feel less close to God than the beginning of the year. Among the three who answered that they feel less close to God, one moved from " 8 " to " 6 ," the other " 5 " to "4," and the last "7" to " $1 . "$

The early adolescent who answered that she feels "1" now from "7" at the beginning of the year, answered that "Nothing that relates to church really appeals to me [her] anymore" and "I have no one and I don't want to talk to anyone." However, she answered that she has two female friends of hers that she "may be" feeling close to or feels that she can talk to about her problems. The other early adolescent who answered " 8 " to " 6 " answered that "Because I [she] don't go to church as often" as before, she doesn't feel close to God. It was observed often that early adolescents were greatly affected by challenges their parents were going through, including not being able to attend the church regularly due to many different personal problems of their parents. The last early adolescent who answered "5" to "4" answered, "I don't feel closer now. I feel distant from him [Him]" and "I feel this way because I haven't had any personal time with him [Him]. I'm always rushing." One of the three early adolescents mentioned 
above answered, "I feel like I have a lot more distractions now, and I think less about God and take less time [with] Him," but feels that "the church has done all they can, and it's just me [her] [to deal with it] for now." Regardless of her opinion, three early adolescents who answered the questions were obviously struggling with spiritual and personal challenges.

On the other hand, among those who answered that they feel closer to God now more than the beginning of the year 2012 answered that attending Sabbath afternoon Bible classes (youth baptismal class), participating in Pathfinder Club and FNL (Friday Night Live) youth vespers services, going on mission trip or mission trips, Sabbath School classes, reading the Bible more often than the previous years, confiding in older youth at the church especially during FNL, attending Pathfinder camping/camporee, joining the clothing drive, praying every day, doing their lessons, doing a sermon/sermonette and getting baptized were the things they did that made them feel closer to God now than before.

Mission Trip, FNL, Pathfinder Club, and Bible Classes

Among all the answers, it was becoming clear that four intentional mentoring and discipleship program/process activities for early adolescents had the most effect and impact on the early adolescents. The two that stood out the most were the mission trip and Pathfinder Club. Among 11 early adolescents who participated in the 2012 ReachOut \& Care Missionary Movement (ROCMM) mission trip in 2012, nine of them answered that the mission trip was a positive experience for them, helping them to feel closer to God now than before. Among the 13 early adolescents who were Pathfinders, 
nine answered that the Pathfinder Club positively affected them, helping them grow spiritually.

Not all early adolescents attended FNL youth vespers service and Sabbath afternoon Bible study (youth baptismal class) regularly, but for those who did, four and five youths respectively said that the two programs helped them feel closer to God and grow spiritually. In addition to what the church offered for the youth, one 10-year-old early adolescent answered that "My [His] parents lead me [him] to God more and more" helping him to feel more close to God. He feels that He is at "9" in his closeness to God moving up from " 8 " because of his parents.

\section{Individual Experiences and Personal Responses}

Some early adolescents described their personal experiences that positively affected them. One 11-year old answered that "I [She] got baptized and went on my [her] first mission trip" that made her feel more close to God moving her from "6" to "8." She participated in all three intentional mentoring and discipleship program/process activities- mission trip, Pathfinder Club, and Bible study (youth baptismal class). One "eleven [and] 1/2"-year-old early adolescent answered, "I went to the mission trip and I learned and was taught how to be like Jesus and to serve one another." He is active in the church, participating in all five mentoring and discipleship program/process activities: mission trip, Bible class (youth baptismal class), FNL, Sabbath School, and Pathfinder Club. $\mathrm{He}$ answered that he now feels " 7 " from " 5 " at the beginning of 2012 .

One 13-year-old answered, "I kept on reading my bible [Bible] more often then [than] the last years" and he mentioned Pathfinder Club and the mission trip that helped him grow spiritually. He moved from "4" to "9" feeling very close to God. Another 13- 
year-old answered that "Attending the mission trips and giving a sermon" made her feel closer to God than before. She also mentioned that "Going to FNL and being able to confide in the older youth" helped her grow spiritually. Another 13-year-old early adolescent answered that "The experiences throughout the year [2012]" and having "a better prayer, I'm [she's] better now at talking to God about certain things." She moved from "5" to " 10 " feeling very close to God. She mentioned that the mission trip and attending Sabbath School and FNL helped her grow spiritually.

One "13.5"-year-old early adolescent answered that "FNL, Pathfinders [Club], mission trips, etc." helped him grow spiritually, but he still feels "7" just how he started at the beginning of 2012. He mentioned that he feels that way "Because I [he] don't feel like I [he] can change."

\section{Early Adolescents' Suggestions to the Church to Help Them Feel Closer to God}

To the question, "What can the church do to help you [early adolescents] feel close to God (or grow spiritually)?" early adolescents answered the following: "Nothing (10-year-old male); Have more activities for my age group (11-year-old female); Have more activities for 10-12 year olds (11-year-old female); I think that the church is doing a great job already[,] but I feel I'm missing something even though I goto [go to] bible [Bible] class. Maybe a little more activities ('11 \& 1/2'-year-old male); '?' (12-year-old female); Tell stories about the bible [Bible], example After [about] David defeated [defeating] golieth [Goliath] (13-year-old male); More activities (early adolescent male); Make Pathfinders [Pathfinder Club] more fun (13-year-old male); Be more upbeat. Sometimes I feel the church is so dead (13-year-old female); AY! We really need it. 
Youth choir (13-year-old female); Make Pathfinders [Pathfinder Club] more fun (13year-old male); More church activities ('13.5'-year-old male); I'm not sure (14-year-old female); Have more programs that relate to teens and not just university people (14-yearold female); and I'm [He's] not sure (15-year-old male)." It was interesting to observe and discover that early adolescents seem to want more than less, especially those who are actively involved in the church.

\section{Go-to-People for Early Adolescents of the Church}

To the question, "Do you have someone who you can talk to about your problems? If yes, who is it or who are they? If not, who do you wish that you can talk to?" Early adolescents answered as follows: "God, because he [He] is always listening \& [and] answering (male); I can talk to god [God] and my parents and paster [pastor] (male); I can talk to my mom with my problems (male); Mom, sister (female); My sister, My parents; My best friend who is Christian too (female); Yes, my brother (male); [names of three older male youths from the church] (male); [name of two older male youths from the church] (male); [name of older female youth from the church], because she understands me \& [and] gives me good advice (female); Yes, My mama, my older cousin in USA (female); Good friends @ [at] church. My mom and dad (female); Yes, my mother (male); My Mom (male); I have no one and I don't want to talk to anyone (female); People I talk to [four names from school and two names from the church] (female); I don't know (female); and Older friends, [name of an older male youth from the church] (male). 


\section{Go-to-People for Early Adolescents Other}

Than Parents

To the question, "Who would you go to other than your parents for help, encouragement, answers to your questions, guidance and support?" Early adolescents answered the following in no particular order (This is to protect the identities of the early adolescents who answered the youth questionnaire): "I would go to Jesus because he [He is best]; Paster [pastor-me], God; [Because] sometimes they [parents] don't understand [so, I would go to someone else]; Sister, [name of a friend from her school]; I would go to the youth leaders [names of two older male youth leaders]; Pastor Moon [church pastor-me]; My brother; [Names of three older male youths including the AY Society leader of the church]; [Names of two older female youth leaders], or Pastor Moon; My older female cousins [Names of her two cousins]; God, [Names of two peers, one from the church and one from the school]; Pastor [church pastor-me]; Pastor [church pastor-me]; Myself [early adolescent herself]; [Names of two peers from the church and one from her school]; Siblings; [Name of older male youth from the church]; and I would go to pastor [church pastor--me].

\section{Who can Early Adolescents go to?}

To the last question, "Is there someone at the church who you feel close to or you feel that you can talk to about your problems? If yes, who is it or who are they?" They answered the following in no particular order: "The church leaders because they know a lot about Jesus; Paster [pastor-me]; [Name of an early adolescent from the church], Pastor Moon [me]; I would go and talk to my friends because they can relate or understand what I feel; No [there is none]; Pastor Moon; Yes, my brother; [Names of 
three older male youths from the church including the AY Society leader]; [Name of an older female youth leader], although she is close to my age; Umm, my mommy, otherwise there is no one; [Name of a female early adolescent from the church, and a male name with 'heart' next to his name who is not from the church, and other female name not from the church]; Nope... [I don't have anyone]; Yes, [but] 'NOT TELLING!'; [Two female early adolescents' names from the church with 'maybe' next to one name]; Not really; and [Names of two older male youths]; and Pastor [church pastor-me].

\section{Personal Observations}

I was quite surprised and pleased to find that some early adolescents found their pastor [me] and parents, especially mothers (no fathers mentioned), as potential persons to go to, to talk about their problems. It was expected that they would find it more comfortable and easier to go to their peers/friends, especially when they are older early adolescents, but I was surprised to find that some early adolescents still felt comfortable to go to their mothers (no fathers mentioned) to talk about their problems. They found their older youths from the church and also their older siblings as a source of support and encouragement. I observed that early adolescents want to feel that whoever would listen to them "understands" what they are going through.

Early adolescents seem to seek out those who would understand and listen rather than to judge them or to pick on them. Early adolescents seem to be seeking those who would listen to them and identify and sympathize with what they are going through and feeling, rather than to judge and to "preach" to them. Even though many of the answers were expected and anticipated, I found it to be encouraging to personally discover that 
significant supportive and encouraging adults are still important and relevant to early adolescents as they grow older, making more tough choices in their lives.

\section{Intended Objectives for Intentional Ministry and Mentoring and Discipleship}

Intentional ministry and intentional mentoring and discipleship which I have been implementing over 10 years at the Kitchener-Waterloo Seventh-day Adventist Church (KWSDAC) for adolescents, especially for early adolescents, were to create a safe and supportive environment for adolescents where they are still welcomed and appreciated as they face challenges to overcome and to grow into spiritual giants. A decade of intentional ministry and intentional mentoring and discipleship were to first keep the members of the church intact. It was to stop the "silent exodus" of our young people. How can we keep our children in our churches? Not just keeping them in the church waiting for them to leave the church one day, but actively engaging them in practicing their religious beliefs. That they would practice selfless, self-sacrificing loving service which is the true Christian identity was the objective for my intentional ministry and intentional mentoring and discipleship project implemented at the KWSDAC.

However, the difficult question still remains. How do we balance between understanding and accepting the challenges of early adolescents as a part of a natural and expected growth process into adulthood, but never failing to positively influence them to make right decisions and choices during their transitional period called early adolescence? At the same time, how do we help them become spiritual icons that positively influence others and effectively change the world around them? Both longterm and short-term mentoring and discipleship were intended to realize a Christian 
identity in our adolescents, that they would grow up to become adults living the sound principles of the Christian identity which is to live a selfless, self-renouncing and selfsacrificing life Jesus once lived here on earth.

The purpose of intentional mentoring/discipling is to produce true followers of Jesus, influencing adolescents to become like Jesus' disciples and true followers who sacrificed all in following their Master Teacher Jesus. This is the true Christian identity.

\section{Notable Findings and Outcomes}

\section{Introduction}

Woody (2011) stated, "During the teenage years, social, emotional, and behavioral problems are common, and it is important that adults in the adolescent's life help with resolving these problems" (p. 159). However, "A teenager can belong only if someone has paid attention to him" (Borgman, 2003, p. 378). Borgman (2003) observed that "So many young people around the world are looking for a 'grown-up' like you to go alongside with them" (p. 411). If we are to minister to young people with wisdom, we need a clear sense of how young people are meant to grow, what is healthy and what is injurious, and how Christ interacts with natural processes. Such determination and commitment to growth may well keep some young people from terminal violence and may encourage young leaders to become significant servants of others (Borgman, 2003, p. 94).

Peterson (1994) pointed out that "the most significant reality in adolescent development is a relationship with God" and that "It is not their sexuality, not their mind, not their social relationships, not their emotions that are at the center - it is God" and "adolescents learn to make choices that affirm their own identity" (p. 16). He also sees 
adolescence as "a gift of God to the parent in middle-age," the process "designed by the Creator to bring children to adulthood" and also "to provide something essential for parents" (Peterson, 1994, p. 2).

Peterson (1994) explained what discipline is,

Closer to the core of the meaning of the word is the image of the master craftsman who takes to himself an apprentice: over a period of years he offers himself as a model, provides guidelines, gives encouragement, points out errors, demonstrates skill, establishes standards, rejects sloppy or carelss work. The discipline involves a personal association that makes it possible for the younger to be shaped by the maturity of the older. The heart of discipline, and the most biblical expression of authority, is careful attention that guides growth. (p. 37)

Kreider (2007) stated about the need for real-life role models,

There is a desperate need for spiritually mature men and women to mentor younger Christians, helping them to clarify what really matters in life and work. Spiritual mentors who act as mature coaches can help younger believers achieve their dreams and visions and feel connected as they integrate life and work and grow to maturity. (p. 14)

Jesus chose " 12 friends from 72 of His followers" to "initiate" His close relationships "to get serious" (Kreider, 2007, p. 114), then the Great Commission, "Go therefore and make disciples of all the nations" (Matt 28:19, NASB) must be carried out purposefully, intentionally, and seriously as the mentors engage with prospective mentees/followers. If to care and nurture, teach and disciple adolescents are a part of God's commission to us, mentoring and discipling adolescents should be considered a privilege that needs to be cherished and appreciated and one that must be carried out intentionally by all, and not just by pastors.

Early Adolescents are Making Serious Life Choices Earlier

One of the most important findings for the adolescents of the KWSDAC is that today's early adolescents (ages 10 to 15 ) are making more difficult, more mature, and 
more "adult-like" choices -- choices which carry serious, negative consequences, much sooner than their peers of previous generations. They are faced with harmful choices like drugs, unprotected sex, pornography, partying, alcohol and tobacco, and other at-risk behaviors such as unhealthy eating habits, self-mutilation, behaviors that contribute to unintentional injuries and violence, unintended pregnancy, acquiring STDs (sexually transmitted diseases), including HIV infections and more. Even older adolescents found this information disturbing that their younger youths are facing those harmful choices that could negatively affect their health and wellbeing with devastating consequences at such an early age. Early adolescents told me that they know their peers who are suffering those devastating consequences because some of their peers made those negative choices. Our children are maturing and becoming more adult-like much faster than previous generations and this is alarming as this would have irreversible and irrevocable effects on them if we do not do something about them. This is why mentoring/discipling early adolescents is needed to help them make wise and well-informed decisions that would allow them to avoid those negative choices with devastating consequences.

\section{Making Positive Choices Resulted in Spiritual Growth}

Early adolescents made positive choices by actively participating in church activities and other intentional mentoring and discipleship program/process activities such as mission trips, Pathfinder Club meetings and activities, FNL youth vespers services, Bible classes (baptismal classes), Sabbath School lesson studies, and other youth ministry events and activities such as feeding the homeless, nursing home visitations, camporees, youth choirs, occasional Sabbath AY programs, youth days, community outreach projects, volunteering and leading out annual VBSs and children's 
Bible series, FOLLOW ME Silent Service Flash Mobs, food drives, clothing drives, and personal and family worships and devotional readings and increased prayer life, resulting in early adolescents' spiritual growth. The more early adolescents engaged and participated in those positive choices offered to them, the closer they felt to God and their spirituality grew.

I was glad that I led the church in offering mentoring and discipleship activities to provide a balance between all the negative choices they are faced with daily. It was evident that those who made good choices were more successful.

\section{Early Adolescents Noticed and Felt Mentor's Presence}

I didn't expect to find too many early adolescents who would consider their pastor, who is in his $40 \mathrm{~s}$, to be the person who they would feel close to or feel that they could talk to about their problems. I was pleasantly surprised to find out that many early adolescents thought that they could come to me for help, encouragement, answers to their questions, and guidance and support. I am sure not all the teens felt this way, but the findings were very encouraging.

\section{Adolescents and Early Adolescents Need Both}

\section{Adult Mentors and Peer-Mentors}

Another important finding is that no matter how hard adults try to limit the influence of their peers, fellow adolescents, especially early adolescents, would never be able to detach or isolate themselves from peer-pressure and/or peer-influences. Adult mentors are important in helping them make good choices, but peer-mentors can be equally effective in helping early adolescents make positive choices. If adult mentors can 
mentor/disciple older youths and young adults who are being peer-mentors to younger youth, there can be a powerful synergy that can bring a life-changing impact in adolescents, especially early adolescents, in their spirituality and faith developments. Utilizing youth leaders who can become positive role models can bring positive peermentoring to younger youth.

I believe the establishment of a youth culture among adolescents that validates and embraces the true Christian identity, is one of the best things that can happen to youth and will make a tremendous difference in peer-mentoring and peer-influence among them. When the majority of older youth believe that it is "cool" and special to set aside one week per year to do an annual mission trip, then positive peer-influence was present that impacted their decisions. Early adolescents at the KWSDAC consider it a privilege to become missionaries when they turn 13 and join ROCMM mission trips. Because some early adolescents were so eager to go on a mission trip, we had to lower the age requirement, especially for those who got baptized at 11 or 12 . Creating positive peer-influence through peer-mentoring can motivate and encourage teens to make good choices and decisions as they seek acceptance and belonging.

However, both peer and adult mentoring can only be effective when people consider them a long-term process, rather than just a one-time, event-oriented program. This is the reason why I tried to utilize programs that were already in place rather than trying to do something completely new and different. Consequently, Friday evening youth vespers services, Sabbath School lessons, Sabbath afternoon Bible studies (baptismal classes), and other community service projects were the means chosen to 
create both long-term mentoring and peer-mentoring relationships between mentors and adolescents.

\section{Mentoring and Discipleship are Processes not Events}

As mentioned above, mentoring and discipleship is a process rather than an event. As some church programs and activities are believed to be effective in adolescent spiritual growth, they are most effective if used to facilitate the ongoing mentoring and discipleship process, rather than being sporadic events. I found that when mentors are too busy or unavailable, they easily become irrelevant and forgotten by mentees, as they are unable to provide help, encouragement, guidance and support because of their absence. I learned that one cannot flip-flop in one's decision to become a mentor. Once the choice is made there is no wavering. Mentors are expected to be accessible and available at all times, especially when adolescents are dealing with difficult choices every day. Inappropriate dependence of mentees on mentors can do more harm than good, and at times, mentoring relationships must be terminated to protect both parties. However, when the mentoring and discipleship process is done appropriately and professionally, with the highest integrity and moral accountability, then it should not be terminated just because a mentor chooses not to be available. It is better for potential mentors with irregular availability not to commit to become mentors, but rather become advisors who would deal with specific situations, rather than committing to relationships that demand a long-term commitment.

I learned from experience that long-term mentoring and discipleship relationships are more effective than short-term ones. In fact, it is almost impossible to have a successful and effective short-term mentoring relationship as it takes time for trust to be 
built between a mentor and a mentee. It is even more difficult for early adolescents to build trusting mentor-mentee relationships with mentors because they seek to be more independent and are more skeptical as they shy away from their parents and other authority figures and seek out friends more.

\section{Summary}

After the long-term ( 7 years) and short-term ( 7 months) intentional mentoring and discipleship relationships with the adolescents of the KWSDAC, many measurable and visible results appeared. The early adolescents who went through the long-term ( 7 years) mentoring and discipleship program are now in universities and are all doing very well academically and spiritually. Two of them got married and are studying to become a pastoral couple, while five are studying to work in the medical field. These youth were appointed and ordained as deacons and deaconesses of the church when they turned 18 and 19. One of the youth leaders served as an AY Society leader for four years and was inducted as an elder in training at the age of 24 in 2011. The current church AY leader is serving and ministering the young people of the church effectively, almost like a youth pastor, as they currently have no youth pastor or a senior pastor who is available to assist.

Many of these youths also served as Sabbath School Superintendents, as assistant church clerks, VBS coordinators, AY leaders, AY Society officers, JAY Society officers, Sabbath School superintendents, church pianist, etc. They organized and executed over a dozen Youth Day divine worship programs each year; some preached, others taught and some are still teaching during the FNL youth vespers services and Sabbath School lesson studies. 
Among those who received mentoring over the five-year period, they are now between the ages of 18-25; all are currently attending the church and actively participating in church programs and service projects.

However, there are a couple of youths who participated in one mission trip and had a conversion experience at the mission field, but no longer attend church due to their personal and family issues. They were discouraged by their unbelieving parents and they no longer attend the church. On the other hand, every single youth who participated in at least three church-sponsored mission trips are faithfully attending the church and playing an active role of service in the church.

As many churches struggle to keep their young people in the pews, the retention rate of the young people in the Kitchener-Waterloo Seventh-day Adventist Church (KWSDAC) since September 2002 (the year when intentional children's ministries and youth ministry were implemented by me) is over $90 \%, 39$ adolescents out of 43 adolescents of the church are still attending the church regularly. Among the adolescents who have participated in at least three of the seven one-week ROCMM (Reach-Out \& Care Missionary Movement) "service learning" mission projects that began in 2007, all of them are actively involved with the church. Forty-three adolescents attended the church during this period regularly and only four adolescents are no longer attending the church. Currently there are over 40 adolescents (10 years and up) attending church regularly, among them, three are away for school, a young married couple (they were baptized and married by me) in their early 20 s is attending an Adventist university preparing to become a ministerial couple, and a student who just graduated and is preparing for entrance into medical school. During the past 7 years, nine youths or 
adolescents moved away with their families to different cities, provinces and/or a different country. Among them are four early adolescents (when they were first mentored by me) who received four years of mentoring while they were attending the KWSDAC. Six of the nine youths mentioned above participated in at least one of either ROMM or ROCMM mission trips. All nine youths (adolescents) who moved away are still active in the church. Over 50 youths and young adults, including a few youths from other churches, all of them adolescents over the age of 10 , have benefitted from the intentional mentoring and discipleship program, during a decade of my ministry at the church, some for a short period and others for longer periods of time.

Among those who stopped coming to the church are: (a) two siblings who stopped attending when their mother, a relatively new Adventist, stopped coming to the church after having some issues with other members; (b) a female youth, a new member who attended the church less than a year, stopped coming after splitting up with her boyfriend whom she had met at the church; (c) a male youth whose church attendance was affected by his parents who have not been attending church for years due to their personal issues.

Even taking into account the above-mentioned young people and one other adolescent who is currently experiencing an "identity crisis" and whose church attendance is sporadic, the retention rate is still close to $90 \%$. This strongly suggests that intentional mentoring and discipleship works in not only keeping our young people in the church, but also helps them to become proactive Christians.

Even though the youth retention rate of $90 \%$ of the KWSDAC is a significant result as it was analyzed for the period of over a decade, another decade would provide a 
more significant analysis of how effective the mentoring and discipleship of the adolescents of the Kitchener-Waterloo Seventh-day Adventist Church has been. 


\section{CHAPTER 6}

\section{SUMMARY, CONCLUSION, AND RECOMMENDATIONS}

\section{Introduction}

People are discovering that long-lasting and "long-term influence with lasting impact comes from significant relationships and role models" and "the long-term positive influence on the lives of students [adolescents] comes from people, not programs" (Burns \& DeVries, 2001, p. 23). Some people call Jesus' earthly ministry “incarnational ministry" (Burns \& DeVries, 2001) when he came to build genuine mentoring and discipleship relationships with young people being considered not only as a teacher, but also as a companion in whom they could confide.

At the beginning of both long-term ( 7 years) and short-term ( 7 months) projects in mentoring and discipling the adolescents at the Kitchener-Waterloo Seventh-day Adventist Church (KWSDAC), I made an intentional effort to develop a mentoring and discipleship program/process which was based on relational elements rather than eventoriented program activities. This intentionality required and demanded not only the presence of the mentor with the youth, but also an enthusiastic and engaging involvement of the mentor in their interests and lives. The mentoring activities provided opportunities for me to effectively teach them the Christian identity and the missionary spirit.

The project was not to create a sophisticated or fancy mentoring and discipleship program or model, adding to the list of many known effective youth ministry programs. 
It was to create an awareness, by showing through the research, that an intentional mentor who loves the young people and who is willing to avail his presence, interest, knowledge, life-experiences, wisdom, time and resources can positively affect adolescents in their making of good choices, and developing healthy Christian identities which will allow them to become proactive Christians.

\section{Summary}

Chapter 1 described the problem that prompted this research. Just like many other churches, the KWSDAC was struggling to retain its youths and young adults. The first generation members of Kitchener-Waterloo Seventh-day Adventists Church failed to keep their children and grandchildren connected to and involved in the Church. Only one family from the founding membership had children from its second and third generation family members still attending church. The church was dealing with the solemn reality that unless there was an intervention, a drastic change in "doing things" in the church, we would continue to lose the young people, resulting in the church closing her doors one day. Chapter 1 described a plan to implement an intentional mentoring and discipleship program/process that would retain the children and adolescents who are still attending the church. The chapter also gave expectations of the project.

Chapter 2 discussed a theological basis for early adolescent mentoring and discipleship. Mentoring and discipleship was defined using the Scriptures, and a historical and cultural background was introduced to help understand the mentoring process for children and adolescents of the first-century Jewish society.

Chapter 3 explored in-depth the development of the early adolescence and established that they go through many changes which confuses and challenges them. 
Developmental theories of early adolescence were also discussed, highlighting the theories that deal with their identity and spirituality. In the chapter, it was established that in order to help early adolescents develop a clear and healthy identity; there was a critical need for mentoring and discipleship. A need for a good mentor was also discussed in the chapter in order for adolescents to achieve a sense of identity through mentoring and discipleship by mentors or peer-mentors.

Chapter 4 described project development and included a narrative of project implementation starting September 2002 for laying the youth ministry foundation, with the year 2006 marking the start of the long-term ( 7 years) mentoring and discipleship program, and the year 2012 marking the start of the short-term (7 months) program. The chapter also described the events and activities that provided opportunities for introducing and teaching the missionary spirit.

Chapter 5 revealed the impact of both the long-term ( 7 years) and short-term ( 7 months) mentoring program that significantly increased the retention rate and community service involvement of the adolescents. The chapter concluded by giving specific examples of how mentoring and discipleship relationships between the mentor and the adolescent mentees positively influenced them.

\section{Conclusion}

When does youth ministry really begin? It is a question we all need to ask to be effective in ministering to our youth. What really is youth ministry? These two questions come from a belief that there is a specific time frame and a particular way to minister to young people that is different from where they have come and where they are going. However, I would like to introduce a different idea. The idea that youth ministry 
really begins before childhood ends. It is a continuous mentoring and nurturing of children, helping them mature and grow in Christ from childhood to adolescence, and eventually into adulthood.

\section{Rethinking Youth Ministry}

\section{When Does Youth Ministry Begin?}

"When does youth ministry begin?" I asked this question of a number of professionals who work with youth, including youth pastors. At first, many did not seem to know how to answer the question. After changing my question to a more specific one, "At what age do you think youth ministry begins?" a few of them answered by saying that they believe youth ministry begins with the "high school age" group, those who are 14 or 15 and up $\left(9^{\text {th }}-12^{\text {th }}\right.$ grade $)$. Some others said that they believe youth ministry begins in the junior high school group, those who are 12 or 13 and up $\left(7^{\text {th }}\right.$ or $8^{\text {th }}$ grade $)$. Still others said that youth ministry begins when the children's ministries end. When asked when the children's ministries end, some said it ends after the primary division $\left(1^{\text {st }}\right.$ $-4^{\text {th }}$ grade / ages 6-9) and others would say that the children's ministries ended after the junior division $\left(5^{\text {th }}-8^{\text {th }}\right.$ grade / ages 10-14). However, when thinking about the question, "what age do you think youth ministry begins?" one will discover that churches which offer youth ministry programs most often gear those programs to high school students and up.

\section{New Trend in Youth Ministry}

In recent years, there has been an increase in the interest of early adolescent youth 
ministry. Ministering, mentoring and discipleship of early adolescents are becoming more and more important as more people are beginning to understand and realize the significance of early adolescence in spiritual formation and identity development. There is an increased awareness and understanding of the importance of early adolescence in recent years and more churches are involved in early adolescent ministry today. Kelcourse (2004) stated, "Church youth programs, which only a few years ago focused on high-school teens, are nearly universally reaching downward in age to include the middle-school student" (p. 206). This new trend in youth ministry among some churches in actively involving early adolescents in their youth ministry program is encouraging. Nevertheless, many churches still don't have an intentional youth ministry program for early adolescents, not to mention the absence of intentional mentoring and discipleship for these early adolescents which are so important in early adolescent spirituality, spiritual growth, faith development, and spiritual and identity formation. Beagles (2009) observed, "At present there seems to be few, if any, attempts within local churches to intentionally disciple/equip adolescents within a relational and not programmatic structure" (p. 96).

The Beginning of Youth Ministry Overlaps

With the end of Children's Ministries

There are five distinctive transitions in the life of a child/youth: preschool, elementary school, junior high and high school, college/university, and postcollege/university years. Often, during the transitory periods, children/adolescents slip through the cracks due to a lack of ministry available to them during those various stages of their transitional periods. The ambiguity of not knowing exactly when children's 
ministries end and youth ministry begins poses many challenges, confusing many church leaders, especially youth ministry professionals. This important reality reminds us that all the ministries should overlap with one another in order for those ministries to be effective in securing the children and adolescents from falling into the cracks, especially for those who are in these transitory periods. Ministry for children/adolescents should overlap rather than be completely separate from one another, as they transition from childhood into adolescence. It should be a continuous process rather than two separate entities. Their spiritual growth must not be interrupted due to a lack of ministry presence as a result of not understanding that youth ministry should overlap with children's ministries.

\section{The Continuum of Youth Ministry}

Youth ministry does not have a distinctive starting point in terms of age, but it should overlap with the latter part of children's ministry. Ministry to children as they become adolescent/youth and then young adults is rather a ministry of progression rather than three distinct entities each surviving on its own. This observation is crucial in ensuring that none of the children who are entering into adolescence fall through the crack because of a lack of ministries available to them. If ministry to children, adolescents/youth and young adults is seen as more of a progressive ministry rather than three distinct and separate ministries, there is less chance of possible "cracks" between ministries since they should all overlap and follow a continuum. This is the continuum of youth ministry. 
Importance of Early Adolescent Mentoring and Discipleship

Adolescence is "maladjustment" by definition, and to adjust to it is a strenuous and often noisy process for everyone involved (Peterson, 1994). It became very clear during the project that early adolescents and their parents were both having many difficulties dealing with how the teens made choices and decisions. The adolescents were confused and worried, but didn't know what to do or who to go to with the daily choices and decisions they were facing.

The FOLLOW ME-Jesus' Mentoring and Discipleship Model

In Jesus' ministry, there exist many principles of mentoring and discipleship. Jesus is the ultimate Mentor. By studying and learning from the Master Teacher through His Word, I developed The FOLLOW ME Model of Mentoring \& Discipleship. Following Jesus' experience encompasses many different ideas of mentoring and discipleship. Jesus said, "Follow My teachings and learn from Me" (Matt 11:29, NLT) (see Appendix A).

Five Adolescent Faith/Spiritual Developmental Stages

After many failed attempts to find a simple and easy-to-remember faith developmental stages model which I could use to help adolescents understand where they are in their faith development or spiritual development, I developed a model that shows five faith developmental stages in the adolescence. These five faith/spiritual developmental stages are relevant to all children and adolescents, including early adolescents who go through the most distinguishable transitional period called puberty. Throughout childhood and adolescence, their brain is still developing and growing with 
their body, enabling them to do abstract thinking, question and reason and make choices of their own. The Five Faith Developmental Stages are: (a) Passive/Inactive Faith Stage; (b) Reactive Faith Stage; (c) Reflective Faith Stage; (d) Active Faith Stage; and (e) Proactive Faith Stage (see Appendix $H$ ).

\section{Stage 1-Passive/Inactive Faith Stage}

In this stage, faith begins in a passive state where the child is indifferent and does what the parents do. At this stage, the parents have the most influence over them. The children do what their parents tell them to do.

\section{Stage 2-Reactive Faith Stage}

During the reactive stage, children will begin to display their simple faith. Two definitions of the word reactive in the Merriam-Webster's dictionary are: "relating to" or "readily responsive to a stimulus." These children will simply react to what they are told. For example, if their parents tell them they should go to church to be saved, they simply believe and follow their parent's example.

\section{Stage 3-Reflective Faith Stage}

As they grow older into adolescence, they now enter the "formal operational stage" where they are now capable of "abstract thinking," and where they begin to question the norms and habits they have acquired during their childhood, such as going to church, giving offering, keeping the Sabbath holy, etc. This is the reflective stage. As they enter into adolescence and puberty, and as their brain develops, they now have the ability to think reflectively, or question what they have heretofore been taught, primarily 
by their parents, often resulting in making positive or negative choices that contribute to either the child becoming an active Christian or an inactive Christian.

\section{Stage 4-Active Faith Stage}

If adolescents make positive choices that would engage them in vibrant religious expression through involvement and service, they would enter into the stage of active faith. They play a major part in, and demonstrate a willingness to, engage in church activities.

\section{Stage 5-Proactive Faith Stage}

By providing mentoring and discipleship which is composed of nurturing and teaching by equipping them with the knowledge and experience of Christ's selfrenouncing and self-sacrificing love and His selfless service which is the true Christian identity, adolescents would then enter into a proactive stage of faith, thereby responding to their Christianity in a self-motivating way. Consequently, at this stage, they exemplify on their own initiative through their own life, Christ's character of humility and service. Often, youths/adolescents that enter this proactive stage of faith change their course of life and live a life more focused on humility and service. Therefore, ministry geared towards youth/adolescents cannot be effective if it is separate from the ministry geared towards only children or older adolescents or young adults.

\section{Summary}

The ministry which began in childhood should continue and develop throughout their adolescence into young adulthood. In this way, instead of finding gaps between different ministries, the faith of children will follow a logical progression throughout 
adolescence and into young adulthood where their Christian faith and experience will be nurtured in a personal and practical way so that as they near adulthood, they will become stronger men and women of God. The success of this progressive ministry cannot be completely effective, however, without the presence of youth ministry professionals or mentors. This kind of ministry must be a ministry based on relationships and the influence of a mentor by his or her engagement and presence.

\section{Recommendations}

The conclusions found in this study generate the following recommendations:

1. That the findings of this study be shared with church leadership, including world headquarters, divisions, unions, conferences and local churches, so that they may become more aware of the need for a youth ministry presence for early adolescents. As the Adventist Church is concerned with the low retention rate of our Adventist young people, the findings of this project is significant, including the high retention rate of the youths who have been mentored, and need to be shared with the church leadership starting from the world headquarters, the divisions, the unions, the conferences, and the local churches. It is also recommended that the church leadership will begin to develop and implement a ministry that is inclusive of early adolescents, specifically after being informed of the findings of the project.

2. To build relationships among fellow pastors and laity who have a common interest in mentoring and discipling others and who are willing to be mentored and discipled themselves. To share the importance of Jesus' mentoring and discipleship, to encourage pastors, laity and conference administrators and officials to involve their own local youth and young adult leaders by encouraging them to attend an annual mentoring 
and discipleship conference where they would be introduced to the FOLLOW ME Mentoring \& Discipleship Model.

3. That local churches would develop long-term and short-term mentoring and discipleship programs/processes using the findings from this study by introducing some mentoring and discipleship events and activities that would allow potential pastoral and lay mentors to develop mentoring and discipleship relationships with early adolescents under the guidance and leadership of the local conferences or the mentors/coaches who attended the "FOLLOW ME" conference.

4. To develop a process that would screen potential mentors by using police checks, references, etc. to ensure the safety and well-being of adolescents, especially the early adolescents who are very vulnerable and naïve. Having a database of the mentors and potential mentors who are working with young people is needed at the conference level to provide coaching, resources, networking, and most importantly, accountability. In order to accomplish this, a certification program would need to be developed and implemented.

5. To develop a network of conference-wide or region-wide mentors where they can be trained to become the kind of mentor that has been described in this study; one who is dedicated, committed, who possesses Christ-like qualities and character who is endowed with the missionary spirit. This network will also provide peer support for mentors themselves and will establish a network of accountability that will help mentors develop a safe and effective mentoring and discipleship presence for early adolescents in their care. 
6. That local churches will be paired with these trained mentors/coaches who can begin their mentoring and discipleship relationships with the early adolescents in their churches and that this mentoring and discipleship relationship between mentor and mentee will follow the FOLLOW ME Mentoring \& Discipleship Model developed in this study/research (see Appendix A).

7. That the faith development stages may be shared with church leadership in order to facilitate the mentoring and discipleship relationships to effectively minister to early adolescents where they currently are in their spiritual life.

8. That local churches begin to provide early adolescents with positive choices in the church, including numerous service projects, church events and activities, mission projects, etc. to provide a positive balance to the negative choices that are so abundant in the life of an early adolescent.

9. That local churches form a team of mentors that will include lay mentors and youth leaders as peer mentors, not just pastor mentors, so that the mentoring and discipleship programs of the local churches will not be affected by the transfer of their pastors and that the programs will continue without interruption. This intentional mentorship and discipleship will provide ongoing coaching and nurturing with love and support to influence the youth and to assist and equip them to positively influence and affect other young people as peer-mentors.

10. To have an annual "FOLLOW ME" conference that brings mentors and mentees together to continue to develop their relationships. NOTE: The first FOLLOW ME Mentoring \& Discipleship Conference was held in 2012. A second Conference was hosted in September of 2013. At both conferences there was attendance by the SDACC 
president, executive secretary (vice-president), communications director, Ontario Conference youth ministry director, the It Is Written Canada speaker, lay mentors (elders, youth leaders and young adult leaders), pastor mentors (including senior pastors and youth pastors), and youth and young adult mentees.

\section{Summary}

Adolescence, especially early adolescence, is a time of transition and many dramatic changes that bring long-lasting and at times life-altering effects. Early adolescents are looking for people, including their parents and other grown-ups, who can make some sense out of what they are experiencing, without being fearful of rejection and retribution by both their peers and adults alike. Youth ministry has often been a ministry of events and activities rather than one of building long lasting mentoring and discipleship relationships between godly mentors or peer-mentors with adolescents or early adolescents. Early adolescents are often forgotten in the church, looking for a place to fit in and belong, but often lost in the world, not knowing who would accept them as they are and love, care, and nurture them.

When I began my youth ministry, it was my love for young people, knowing and believing that they have great potential and a significant future ahead of them and that if I could only impact them in some way, their entire lives would be changed forever for the better. As I witnessed so many young people leaving the church, I felt a burden on my heart for these youth and wondered why. It was then that I realized that I was one of them and the reason why I had ended up leaving the church at one point in my life was because I didn't have someone there who I thought cared about me, no one to whom I could go to for counsel, understanding, forgiveness, encouragement, guidance, but most 
importantly, unconditional love and acceptance. It was this experience that changed my outlook of youth ministry.

What is the use of all the programs if they fail to allow our young people to experience the love and the grace of God? I decided then that I would be the one to provide unconditional love and acceptance to young people who are experiencing what I experienced in my adolescence. It is this love that I have for young people that keeps me spending hours with them when my body is telling me that I should leave them to care for myself.

I often wonder what Jesus did when He was here on earth. Long after many creative, exciting, and moving youth ministry events and activities are over, after countless hours spent indoctrinating our young people, long after our sermons and Bible study lessons are forgotten, what our young people will remember is the one who always had time for them, always had time to listen to them, always available to listen to their problems without judging or preaching. It is this loving and caring mentoring and discipleship relationships that our young people will remember.

What will change the lives of young people is not the event oriented youth ministry program which strives to be more "entertaining" or "exciting," but rather, it will be the mentoring and discipleship relationships that are built between young mentees and loving and committed mentors. These selfless and Christ-like mentors will be remembered when the excitement and hype of events subside. They will have the greatest influence and the longest lasting effect on the young people.

If youth ministry professionals are constantly present in the lives and faith experiences of children, youth/adolescents and young adults, the ministry becomes 
strengthened and more effective. Children, youth and young adults often learn from their mentors who provide constant ministry and care for them. This is the area where many churches have failed and have become less effective in reaching out to our young people and in making a difference in their lives.

What we need is not another youth ministry program, but authentic and genuine Christian mentors who can command others to follow Jesus with confidence, because they are following Him. Our young people would desire to watch and follow us because we are first following Jesus and they can see clearly that Jesus the Master Teacher is our LORD and Savior. 
APPENDIX

153 


\section{APPENDIX A \\ THE FOLLOW ME JESUS' MENTORING \& DISCIPLESHIP MODEL}

In Jesus' ministry, there exist many principles of what many understand individually as mentoring and discipleship. Jesus is the Mentor who showed us what mentoring/discipleship is all about. By studying and learning from the Master Teacher through His Word, I developed The FOLLOW ME Model of Mentoring \& Discipleship following Jesus' mentoring and discipleship examples to assist those who are looking to build mentoring and discipleship relationships with others. Following Jesus' experience encompasses many different ideas of mentoring and discipleship. Jesus said, "Follow My teachings and learn from Me" (Matt 11:29, NLT).

\section{F-Forgiveness, Friendship, Fellowship.}

In Jesus' earthly ministry, His ministry was filled with stories of forgiveness, friendship and fellowship. Jesus not only reminded Peter to forgive (Matt 18:21-35), but He pronounces, "For this is My blood of the covenant, which is poured out for many for forgiveness of sins" (Matt 26:28, NASB). When He saw the paralytic and his company, He said to him that his sins are forgiven (Matt 9:2; Mark 2:5; Luke 5:20). To a sinful woman who washed Jesus' feet, He told her that her sins are forgiven (Luke 7:48). Paul said, "I want you to know that through Jesus the forgiveness of sins is proclaimed to you" 
(Acts 13:38, NIV). Jesus said His assuring and comforting words to the woman who was caught in the act of adultery, "neither do I condemn you... Go now and leave your life of $\sin "(J o h n$ 8:11, NIV).

Forgiveness is much needed in developing mentoring and discipleship relationships with adolescents as they are faced with many lifestyle choices with negative consequences they often find themselves choosing as a result of peer-pressure. Peterson (1994) stated, "Forgiveness is the act that makes bad news convertible to good news by providing the opening for the Holy Spirit to take episodes of adolescent sin and make them into stories of mature love" (p. 108).

There was much friendship and fellowship in following Jesus even with the sinners. Jesus looked up to Zacchaeus and said, "Come down immediately. I must stay at your house today" (Luke 19:6). What He did was not popular as Zacchaeus was a tax collector who was treated like a second-class citizen or worse. However, Jesus didn't mind befriending and fellowshipping with a sinner like him. Zacchaeus, an example of a sinner's experience of Jesus' forgiveness, friendship and fellowship changing him, declared, "Here and now I give half of my possessions to the poor, and if I have cheated anybody out of anything, I will pay back four times the amount" (Luke 19:8, NIV). What a fellowship as Jesus announced that Zacchaeus, "this man, too, is a son of Abraham" (Luke 19:9, NIV).

White (1905) stated,

Christ's method alone will give true success in reaching the people. The Saviour mingled with men as one who desired their good. He showed His sympathy for them, ministered to their needs, and won their confidence. Then He bade them, "Follow Me." (p. 143) 
Jesus met the people where they were. Jesus' forgiveness, friendship and fellowship knew no boundaries and His compassionate and empathic encounters with sinners were the beginning of a new life for them.

\section{O-Openness, Honesty, Sharing}

In experiencing Jesus, there was openness, honesty, and sharing. Jesus talked with a Samaritan woman who was a stranger, a woman who no Jews would even care or dare to spare a moment of their time to be with (John 4:1-26). In His dialogue with her, He demanded her to be honest and share her painful stories of constant needs and thirst. He encouraged her to open up as He reminded her that she indeed had five husbands and the one she was with was not her husband either (John 4:18). Jesus never hesitated in engaging in an open and honest dialogue with those who were outcasts, neglected, abandoned and alienated from the cares of others.

Sensing the need for a deeper healing, Jesus asked the woman who had just been cured of her 12 years of bleeding (Matt 9:20-22; Mark 5:24-34, Luke 8:43-48), "Who touched My garments?" (Mark 5:30, NASB). Jesus was more interested about and concerned with her spiritual state and wellbeing that, with His openness, He required that she be honest with Jesus so that her life story of faith could be shared with others. To this lonely woman who suffered much loss, Jesus said, "your faith has healed you" (Mark 5:34). Mallison (1998) pointed out that "The openness and honesty we will need to make effective mentoring relationships grows out of our openness with and obedience to God" (p. 28). In following Jesus there was spirit of openness, honesty, and sharing. 


\section{L-Love (Agapao), Unconditional Self-Sacrificing \\ Love, Lowliness, and Humility}

After Peter's betrayal, Jesus once again appealed to him (John 21:1-6) in the same manner, almost identical to the one that he experienced previously (Luke 5:1-8), when "he left everything and followed Him" (Luke 5:11, NASB). There Jesus asked Peter, "lovest (agapao) thou me more than these?" and again "lovest (agapao) thou me?" when both times Peter replied by saying "I love (phileo) thee" and "I love (phileo) thee" (John $21: 15,16$ ). When He taught His followers/disciples, He taught them to love (agapao) God and others (Matt 22:37-40). It is clear that after Peter's denials of Jesus, when Jesus was asking him whether he loves (agapao) Him, Peter could not tell Him that he loves (agapao) Jesus as Jesus commanded His followers/disciples to selflessly love (agapao). Regardless of Peter's answers, Jesus went to Peter to reinstate him in spite of his betrayal (John 21:15-20) and once again bade him to "Follow Me!" (John 21:19, NASB). In following Jesus, the followers/disciples of Jesus not only received Jesus' forgiveness, they also felt and experienced Jesus' unconditional love and acceptance.

This love is selfless and self-sacrificing, which prompted Jesus to care for the people who were in need, deprived, and neglected. He healed and provided for the needs of the people. Out of His love, care and compassion, He fed the five thousand men (Matt 14:13-21; Mark 6:32-44; Luke 9:10-17; John 6:1-13) and later the four thousand (Matt 15:29-39; Mark 8:1-10).

Jesus' self-renouncing and self-sacrificing love was shown through His lowliness and humility. His incarnation attests that He is the Lowly One and the Humble One. Jesus' lowliness and humility are His trademarks, differing from other worldly rabbis who pursued for public recognition and honor. On the other hand, Jesus went to meet the 
lowly where they were, not judging them for how they were, but welcoming them, ready to accept them to experience His unconditional love, care, and acceptance. During the Last Supper, Jesus washed His disciples' feet, task only slaves and servants were required to do (John 13:1-17). Adolescents are looking for mentors who emulate Jesus' humility and lowliness, who are "down to earth" and willing to associate with the "lowly ones".

The expectation was there for everyone who was following Jesus to love one another as Jesus loved them (John 13:34). Jesus said, "By this all men will know that you are My disciples, if you have love for one another" (John 13:35, NASB). White (1898) states that the only condition of discipleship and service is loving Jesus and "This is the essential qualification" (p. 815) and this love is unconditional, self-renouncing and self-sacrificing, that love which is the true Christian identity, the missionary spirit.

\section{L-Loyalty and Long-suffering and Patient}

When Jesus preached His Sermon on the Mount (Matt 5-7), He spoke about the importance of loyalty, urging people that no one can serve two masters (Matt 6:24, Luke 16:13). Jesus commanded, "But seek first His kingdom and His righteousness, and all these things will be added to you" (Matt 6:33, NASB). What Jesus expected from His followers/disciples was for them to learn to trust Him completely and be loyal and faithful to Him. God is long-suffering (Jer 15:15) and patient (1 Pet 3:20; 2 Pet 3:9) and that same attributes were seen in Jesus during His earthly ministry.

In Jesus' relationship with His disciples, He not only showed His love and compassion, but He also showed His patience and long-suffering. Jesus' dialogue with Peter at the Sea of Galilee after his betrayal, Jesus showed His long-suffering and patience for the one who denied Jesus three times (John 21:15-17). 


\section{O-Obedience}

Obedience was something that Jesus expected from His followers/disciples. Jesus said, "whoever obeys my word will never see death" (John 8:51, NIV). He also said, "Anyone who loves me will obey my teaching" (John 14:23, NIV) contrasting with the next verse, "Anyone who does not love me will not obey my teaching" (John 14:24, NIV). Christian mentors must be obedient to God and they should be able to demand obedience to God's commands and His will/teachings from his mentees/followers. Jesus commissioned His disciples to go and make disciples of all nations and teach them to obey everything Jesus commanded and taught (Matt 28:19, 20).

\section{W-Worship and Witnessing}

Jesus said, "Worship the Lord your God, and serve him only" (Matt 4:10, NIV). Jesus quoted Deut 6:13 and said, "It is written: 'You shall worship the LORD your God and serve Him only" (Luke 4:8, NASB). Jesus said, "But an hour is coming, and now is, when the true worshipers will worship the Father in spirit and truth; for such people the Father seeks to be His worshipers" (John 4:23, NASB). In the example of the man who had been cured of blindness, when Jesus told him that He is "the Son of Man" (John 9:35, NASB), "he worshiped Him" (John 9:38, NASB).

Worship is more than just attending church, singing hymns, praying and listening to a sermon. Worship is recognizing God as our Creator, Master, and Lord and giving homage to Him. Paul pleaded, "Therefore I urge you, brethren, by the mercies of God, to present your bodies a living and holy sacrifice, acceptable to God, which is your spiritual service of worship" (Romans 12:1, NASB). Middendorf (2000) stated, "Because we only have one word for worship while the Greek language used several, we miss out on the 
true meanings and nuances the original authors intended" (p. 53). Middendorf (2000) stated that worship is about the story, "The stories of God's faithfulness and love are the inspiration and fuel powering true, worshipful responses" (p. 53), and worship is not a religious exercise, but a relationship of responding to God's love, and a renewed lifestyle.

Another important aspect of following Jesus is to be a witness. Jesus said, "you are witnesses to these things" (Luke 24:48, NASB) and also "you shall be My witnesses both in Jerusalem, and in all Judea and Samaria, and even to the remotest part of the earth" (Acts 1:8, NASB). In these two verses, the word "witnesses" is from the Greek word martures. It is interesting to note that Jesus also refers to Himself as "the faithful witness" (Rev 1:5, NASB) and they share the same word. Innes (1985) noted that Christians by virtue of the fact that they are Christians, without doing anything, are automatically witnesses for Jesus Christ and representatives of His kingdom.

\section{M-Modeling, Mentoring and Discipling Others}

In addition to Jesus' command to Peter in Luke 22:32, Jesus reminded Peter of the first call he received when Jesus told him that he will be a fisher of men and he "will fish for people" (Matt 4:19; Luke 5:10, NIV). Jesus told Peter to feed His lambs and take care of His sheep (John 21:15-17). The Greek word for "feed" in John 21:16 is poimaino and it means "to shepherd." Jesus is known as the Shepherd and he expected Peter to take care of His sheep. Not only did Peter receive mentoring and discipleship from Jesus as one of the disciples, but now Jesus was expecting him to be a mentor and a discipler. Here the call is not only about receiving mentoring and discipleship, but also now to become a mentor to mentor and disciple others. 
Teaching is also an important part of discipleship. Jesus said to His followers/disciples to teach to obey everything Jesus commanded (Matt 28:20). Bonhoeffer (1963) stated, "Christianity without discipleship is always Christianity without Christ" (p. 64):

Modeling is another important aspect of Christian mentoring and discipleship. Paul commanded the Corinthians, "Be ye followers of me, even as I also am of Christ" (1 Cor 11:1). The word "followers" comes from the Greek word mimetai which means "imitators" and the word "mimics" comes from this Greek word. Another version reads, "Be imitators of me, just as I also am of Christ" (1 Cor 11:1, NASB) and "Follow my example, as I follow the example of Christ" (1 Cor 11:1, NIV). This is Christian modeling and Jesus expects His followers/disciples to become role models to others.

\section{E-Empowered to Serve and Self-Sacrifice, and Evangelize}

Jesus taught the importance of service and self-sacrifice, "He who loves his life loses it, and he who hates his life in this world will keep it to life eternal" (John 12:25, NASB). After emphasizing the importance of self-sacrifice and self-abnegation, $\mathrm{He}$ stated, "If anyone serves Me, he must follow Me; and where I am, there My servant will be also; if anyone serves Me, the Father will honor him" (John 12:26, NASB). He talked about the importance of self-sacrifice and service.

Jesus expected His disciples to follow His path and suffer as Jesus did. Tradition says that all ten of Jesus disciples, except John the beloved and Judas Iscariot, died as martyrs. 1 Pet 2:21 reads, "For you have been called for this purpose, since Christ also suffered for you, leaving you an example for you to follow in His steps" (NASB). In 
Matthew 20:26-28, Jesus said, "whoever wishes to become great among you shall be your servant, and whoever wishes to be first among you shall be your slave" as Jesus "did not come to be served, but to serve, and to give His life a ransom for many" (NASB).

Explaining Legitimate Peripheral Participation, Csinos (2010) showed that Jesus' method of teaching on earth was a model of apprenticeship, "Information, therefore, is not so much the desired outcome of learning as it is the ability to experience full participation in a community by engaging in its practices" through participation with "old-timers", as newcomers gradually "come to experience full participation in a community of practice" (p. 46).

Jesus reminded His disciples that the cost of His discipleship will be great as $\mathrm{He}$ said to them, "If anyone wishes to come after Me, he must deny himself, and take up his cross and follow Me. For whoever wishes to save his life will lose it; but whoever loses his life for My sake will find it" (Matt 16:24, 25, NASB).

Christ's imperative and central lesson of self-sacrificing love is also shared by Paul in Phil 3:7, 8:

"But whatever things were gain to me, those things I have counted as loss for the sake of Christ. More than that, I count all things to be loss in view of the surpassing value of knowing Christ Jesus my Lord, for whom I have suffered the loss of all things, and count them but rubbish so that I may gain Christ." (NASB)

White (1985) stated the following,

Following Christ, as spoken of in these words, is not a pretense...Jesus expects His disciples to follow closely in His footsteps, enduring what He endured, suffering what He suffered, overcoming as He overcame. He is anxiously waiting to see His professed followers revealing the spirit of self-sacrifice. (p. 230)

Jesus also taught the disciples to go and evangelize; making disciples, baptizing them and teaching them to obey everything Jesus commanded (Matt 28:19,20). Jesus 
chose us to go and "bear fruit—fruit that will last" (John 15:16, NIV). Jesus appointed

the twelve to send them out to preach (Mark 3:14). Jesus did not want following Jesus to be stationary or stagnant, but He sent them out to preach the Gospel, the Good News.

\section{Summary}

To summarize how Jesus mentored and discipled those who were following Jesus, White (1911) shares the following:

For three years and a half the disciples were under the instruction of the greatest Teacher the world has ever known. By personal contact and association, Christ trained them for His service. Day by day they walked and talked with Him, hearing His words of cheer to the weary and heavy-laden, and seeing the manifestation of His power in behalf of the sick and the afflicted. Sometimes He taught them, sitting among them on the mountainside; sometimes beside the sea or walking by the way, He revealed the mysteries of the kingdom of God. Wherever hearts were open to receive the divine message, He unfolded the truths of the way of salvation. He did not command the disciples to do this or that, but said, "Follow Me." On His journeys through country and cities, He took them with Him, that they might see how He taught the people. They traveled with Him from place to place. They shared His frugal fare, and like Him were sometimes hungry and often weary. On the crowded streets, by the lakeside, in the lonely desert, they were with Him. They saw Him in every phase of life. (pp. 17-18)

Burns and DeVries (2001) made this very important observation and stated,

In order to have an important influence in the lives of young people, you do not need to be a dynamic speaker, know all the latest music, or even dress in the latest fashions. You must, however, love kids and be willing to spend time with them, which is what effective, relational youth ministry is all about. Effective youth workers may never be polished, dynamic communicators or highly creative programmers; but they do need to have a heart of compassion, a listening ear and a willingness to get to know the students [young people] in their youth ministry. Genuinely caring for your students [young people] is the primary prerequisite for working with them. (p. 24)

This is what the theology of FOLLOW ME is all about and the method of Jesus' ministry should serve as a model for mentoring and discipleship. The FOLLOW ME Model of Mentoring \& Discipleship is especially valuable for early adolescents, given the nature of their characteristics and tendencies. Early adolescence being the period of 
major changes for early adolescents, Jesus' FOLLOW ME ministry model of being an example for them to follow is profoundly affective and effective. Mentoring and discipleship share common principles and practices and they can be used inclusively in implementing The FOLLOW ME Model of Mentoring \& Discipleship.

Both the words mentoring and discipleship in my model is being used interchangeably in order to refer to the larger application of Jesus' FOLLOW ME ministry model. Jesus' FOLLOW ME ministry model is not limited or confined to The FOLLOW ME Model of Mentoring \& Discipleship I created, but as more to be discovered. 


\section{APPENDIX B}

\section{ADOLESCENTS' CHOICES}

The following are the choices adolescents are faced with according to the

adolescents of the Kitchener-Waterloo Seventh-day Adventist Church (KWSDAC).

\section{EARLY ADOLESCENTS' (10-14) CHOICES}

High school, peers/friends, drugs, clothes/hair, relationships/sex, parties, sites to view/internet, jobs, peer pressure, $\$[$ money , responsibility, school teams, boyfriends/girlfriends, hygiene, alcohol/smoking, things you buy, cell phones, respecting parents, school work, modesty, involvement @ [at] school, food, popularity, electives, how you act towards people, how you treat your body, God/religion.

\section{EARLY ADOLESCENTS' (15) \& MIDDLE ADOLESCENTS' (16-18) CHOICES}

What classes should I take? Saying no to drugs. Should I eat? Should I smoke? Saying no to b-day parties on Sabbath. Saying no to parties. Should I hang out with certain ppl [people]. Should I go to class. T.V. Type of entertainment. Obeying parents. Defining relationship with Jesus. Inappropriate language. Should I buy this? Should I be sexually active? Peer-pressure (following trends). Evolution argument. Relationships. Should I shave? What can and cannot do on the Sabbath? Judging people. University. Driving. Rebelling. Should I move out? Reduce, Reuse, Recycle.

\section{LATE ADOLESCENTS (19-mid 20s) CHOICES}

[The following responses are the choices the 19-25 year olds of the KWSDAC made at each point in their life: when they were between 10-14, then, at 15-18 and finally, the current choices they have to make at 19-25 years of age]

While they were 10-14: Sports or music lessons? What martial arts am I going to take? Who will my friends be? What will my hobby be? Whether or not to attend worship service/sleep in church?

While they were 15-18: Which university/college will I go to? Will I go to work force? What will be my major? Girlfriend/boyfriend choice? Premarital sex. Should I follow my parents' religion?

19+: To drink or not to drink? Drug/substance abuse. Graduate school or work after university? Or a professional school? Looking for a future spouse. Choosing a responsibility/role in church. Choice of political views. Building professional network contacts. 


\section{APPENDIX C \\ EARLY ADOLESCENT MALES' CHOICES}

\section{Questions:}

1. How much do my parents know me?

2. What are the top three most difficult choices you are faced with?

3. What are some things that you can do to help you grow spiritually?

4. What have you done in the past that helped you grow spiritually?

\section{0-YEAR-OLD EARLY ADOLESCENT MALE'S CHOICES}
1. $53 \%$.
2. What to wear, friends and what to do?
3. Reading Bible, prayer, trying to not sin.
4. Baptized.

\section{1-YEAR-OLD EARLY ADOLESCENT MALE'S CHOICES}

1. $89 \%$.

2. What friends this week, What to buy, Whether to get Minecraft.

3. Having my own personal devotion every morning and evening.

4. There was a baptismal class at church.

\section{1-YEAR-OLD EARLY ADOLESCENT MALE'S CHOICES}

1. $100 \%$.

2. Carots [Carrots], salad, dogs.

3. The Bible, chars, Moon.

4. Love \& Bible.

\section{2-YEAR-OLD EARLY ADOLESCENT MALE'S CHOICES}

1. $96 \%$.

2. Where to go for my birthday, What phone plan to stay with, How to unbored myself.

3. Daily Devotion, Prayer, Trying not to sin.

4. Having personal worship!!!

\section{2-YEAR-OLD EARLY ADOLESCENT MALE'S CHOICES}

1. $100 \%$.

2. [No answer].

3. By having more programs in the church, by reaching [learning] the bible with the pastors. 


\section{APPENDIX D \\ EARLY ADOLESCENT FEMALES' CHOICES}

\section{Questions:}

1. How much do my parents know me?

2. What are the top three most difficult choices you are faced with?

3. What are some things that you can do to help you grow spiritually?

4. What have you done in the past that helped you grow spiritually?

\section{2-YEAR-OLD EARLY ADOLESCENT FEMALE'S CHOICES}

1. $45 \%$.

2. If I should buy extensions (hair), Honesty with your parents, If I should buy a Blackberry.

3. Bible, Church, Healthy relationship with God, Pastor.

4. Me getting a Bible.

\section{3-YEAR-OLD EARLY ADOLESCENT FEMALE'S CHOICES}

1. $100 \%$.

2. Not to steal, Not Curse, Not to disable my Fb [Facebook].

3. Bible, Prayer, Worship.

4. Having Personal Worship.

\section{3-YEAR-OLD EARLY ADOLESCENT FEMALE'S CHOICES}

1. $60 \%$.

2. Drugs, what to wear (modesty), friends.

3. Encouraging friends, daily prayer \& meditation, personal devotion, opportunity.

4. Deciding to read a personal devotional book \& applying the lessons.

\section{3-YEAR-OLD EARLY ADOLESCENT FEMALE'S CHOICES}

1. $65 \%$.

2. Should I care about what I look like? What to wear? What to buy?

3. Applying quarterlie [quarterly] the lesson to my life, Praying more.

4. Undecided.

\section{4-YEAR-OLD EARLY ADOLESCENT FEMALE'S CHOICES}

1. $85 \%$.

2. Getting twitter, What high school to go to, wearing leggings.

3. The Bible, Christian Music.

4. Having worship in da morning. 


\section{APPENDIX E}

\section{EARLY ADOLESCENT FEMALES' PARENTS' RESPONSES}

\section{Questions:}

1. How much do you know your adolescent child?

2. What are the challenges/choices your adolescent child is faced with?

3. What things are helping your adolescent child grow spiritually?

4. What are some of the challenges you are experiencing with your adolescent child?

\section{EARLY ADOLESCENT FEMALE'S PARENT'S RESPONSE}

1. $80 \%$.

2. Drugs, the opposite sex, fear of high school, smoking, the Internet.

3. Daily devotion, family praise \& worship.

4. Back talking, disrespect, constant fighting with sister, potty mouth@ school, disobedience.

\section{EARLY ADOLESCENT FEMALE'S PARENT'S RESPONSE}

1. $80 \%$.

2. To choose between right from wrong associated with peer pressure.

3. Positive aid to my child's transitioning to puberty was the mission trip / inclusion within the church circle.

4. Obedience, to read the Word of God, balancing school \& church activities.

\section{EARLY ADOLESCENT FEMALE'S PARENT'S RESPONSE}

1. $90 \%$.

2. Choice of friends; music to listen to; continue to trust God \& build their faith in God; career to choose.

3. Going on mission trip - the first one for my child; spiritual experience was excellent.

4. Building their faith $\&$ trust in God; Encourage personal devotion time.

\section{EARLY ADOLESCENT FEMALE'S PARENT'S RESPONSE}

1. $80 \%$.

2. Peer Pressure, Relationship with the other sex, Religious belief (e.g. Halloween).

3. Pathfinders, mission trip, being more active in church.

4. Being more responsible, not being challenged (thinks less of self always takes easy way out). 


\section{APPENDIX F \\ EARLY ADOLESCENTS' \& ADOLESCENT'S PARENTS' RESPONSES}

\section{Questions:}

1. How much do you know your adolescent child?

2. What are the challenges/choices your adolescent child is faced with?

3. What things are helping your adolescent child grow spiritually?

4. What are some of the challenges you are experiencing with your adolescent child?

\section{3-YEAR-OLD EARLY ADOLESCENT'S PARENT'S RESPONSE}

1. $70 \%$.

2. The way they clothe themselves, Challenges of changing hormones.

3. Transitioning from childhood to adolescence (positive influence): every summer mission trip, VBS / FNL-Friday Night Live, Evangelistic Series for children.

4., Staying up late (the child reads in bed oblivious of the time), bickering with younger sibling, too bossy with younger sibling, doesn't want to be told the obvious, trying to test their limit (talking back to parents sometimes).

\section{ADOLESCENT FEMALE'S PARENT'S RESPONSE}

1. $70 \%$.

2. Choice of standing alone and being different (by not participating in Sabbath hours activities).

3. Positive transition was continuing to read Bible daily.

4. Child not feeling able to talk about hurt feelings rather keep to themselves, Not obeying parents decisions, wanting to make own.

\section{EARLYADOLESCENT PARENT'S RESPONSE}

1. $70 \%$.

2. Choices: Social Media, School Work, Friends, Food.

3. Mission Trips, Pathfinder Club, Sabbath School, VBS, Outreach Programs of Church, Family Worship, Girls' night out.

4. Obedience, Food Choices, Clothes/Dress Choices. 


\section{APPENDIX G}

\section{EARLY ADOLESCENT MALES' PARENTS' RESPONSES}

\section{Questions:}

1. How much do you know your adolescent child?

2. What are the challenges/choices your adolescent child is faced with?

3. What things are helping your adolescent child grow spiritually?

4. What are some of the challenges you are experiencing with your adolescent child?

\section{EARLY ADOLESCENT MALE'S PARENT'S RESPONSE}

1. $80 \%$.

2. What high school will I go to, when/who will I date (the person who I have found that I like), dealing with peer pressure, clothing styles liberal/conservative.

3. FNL-Friday Night Live, older brother \& sister in the church, role models (mentors).

4. Sometimes strong willed, butts heads with parent.

\section{EARLY ADOLESCENT MALE'S PARENT'S RESPONSE}

1. $60 \%$.

2. Afraid to the dark and be alone, and violence in the family.

3. Pathfinder Camporee, and with to growth in Spiritual life (positive transition). To learn some sports such as soccer, volleyball, etc.

4. To study at college/university (personal challenge), Don't get marry to young, or get girlfriend. 


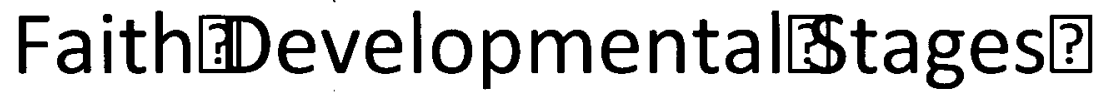

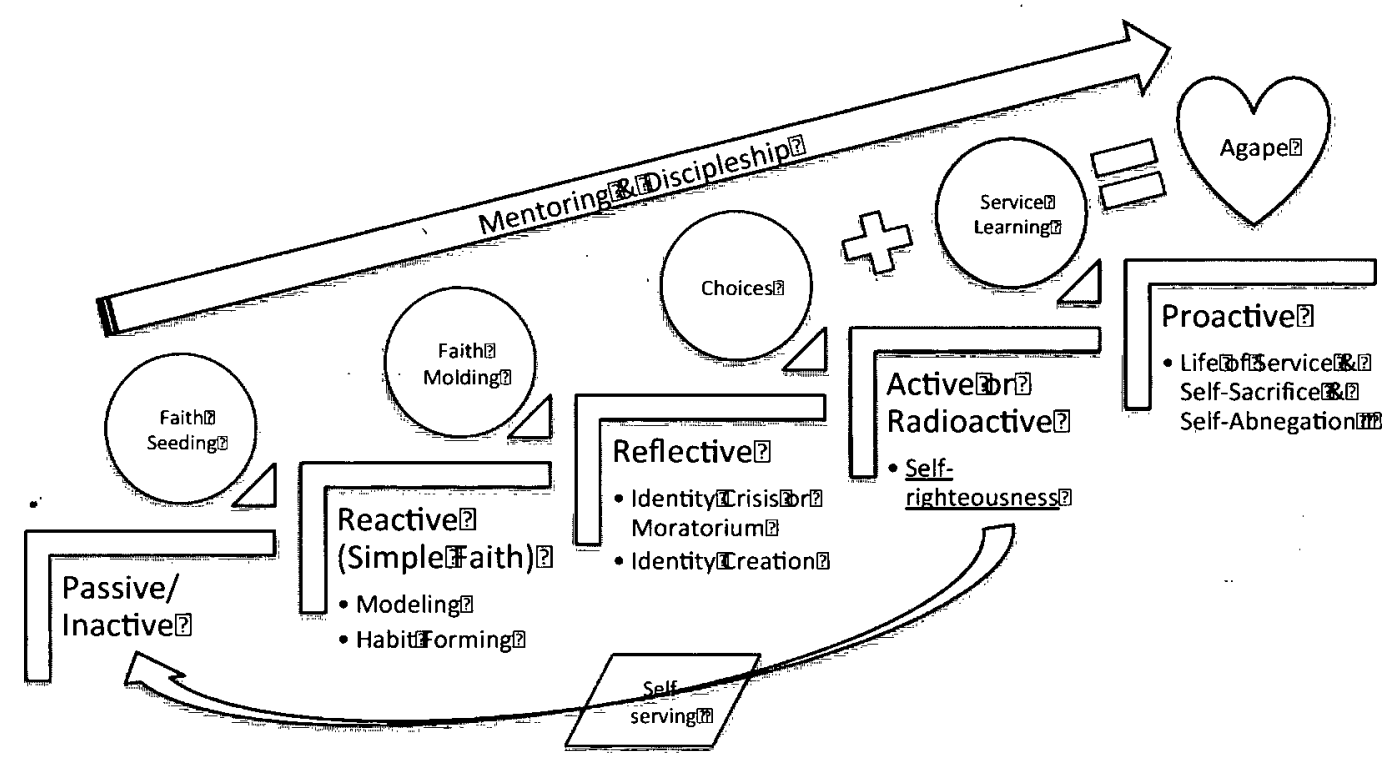




\section{APPENDIX I}

\section{YOUTH QUESTIONAIRE}

Youth Questionnaire

Kitchener-Waterloo Seventh-day Adventist Church

Age:

Gender: Male (. ) Female ( )

1. How close did you feel to God at the beginning of 2012? (Please circle one number) (Weakest) (Average) (Strongest)
0
45
6
8
$9 \quad 10$

2. How close do you feel to God now? (Please circle one number) (Weakest)

3. If you feel more close to God now than before, what helped you (or what did you do) in 2012 to feel closer to God more than before?

4. Please name a couple of church activities that you participated in 2012 that may have helped you feel close to God (or grow spiritually)?

5. If you don't feel close to God, why do you feel that way? Name some reasons why.

6. What can the church do to help you feel close to God (or grow spiritually)?

7. Do you have someone who you can talk to about your problems? If yes, who is it or who are they? If not, who do you wish that you can talk to?

8. Who would you go to other than your parents for help, encouragement, answers to your questions, guidance and support?

9. Is there someone at the church who you feel close to or you feel that you can talk to about your problems? If yes, who is it or who are they? 


\title{
APPENDIX J
}

\section{INFORMED ASSENT/CONSENT FOR PARTICIPATION IN RESEARCH PROJECT}

\author{
Andrews University \\ Doctor of Ministry \\ Informed Assent/Consent for Participation in Research Project
}

The six months project "Mentoring and Discipling of the Early Adolescents of the KitchenerWaterloo Seventh-day Adventist Church" involves a research project that will be done by Pastor Jiwan S. Moon for his studies in Youth \& Young Adult Ministry at Andrews University. The research will be done mostly at the Kitchener-Waterloo Seventh-day Adventist Church during the Friday Youth Vespers service, the youth Sabbath School lesson study, and Sabbath afternoon programs. Also, sometimes, the participants or youth in the program will be involved in activities outside the church in the community about once a week where they will help or serve others in need.

\section{About the Research Project}

This research project is going to create a program that mentors and disciples early adolescents in the Kitchener-Waterloo church. The success of this program will be evaiuated by seeing if the youth are more involved in serving and helping others in the church and community after this mentoring program than before it. With the parents' help, a discipleship group will be formed, early adolescent-oriented events, activities and a long term project will be developed and implemented and there will be three to five hours per week of pastoral mentoring and discipleship provided for the youth in the program. The early adolescents will be asked to keep journals that will be used in evaluating how effective the mentoring and discipleship program was. Parents may contribute in the research by giving their feedback based on their observation of the child/children participating.

\section{What is Expected of You}

- If you participate in this research project, you have to attend the mentoring and discipleship programs regularly.

- You have to keep a journal of your experiences and at the end of the project, give this journal to the researcher (Pastor Moon).

What Are the Benefits of This Research Project

- Your spiritual life may grow because of this program because you will be more involved in church life serving and helping others after learning the importance of it.

\section{Confidentiality}

- Your journals will only be read by the researcher (Pastor Moon) except in situations when information in those journals shows that your well-being may be threatened.

- The Facebook group will be created for the participants (you) and their (your) parents, the researcher (Pastor Moon), and the AY Society leader for announcements and inspirational quotes to be posted. Whatever you post on Facebook will be viewed by other people and privacy and confidentiality is not guaranteed.

\section{Voluntary Participation}

- You are participating in this research project because you choose to and if you choose not to, you can stop participating at any time. 


\section{Risk of Injury}

In the unlikely event of injury or death because of participating in these activities, neither the Kitchener-Waterioo Seventh-day Adventist Church nor Andrews University, nor any other church organizations are able to offer financial compensation or to absorb the costs of medical treatment. However, assistance will be provided to research subjects in obtaining emergency treatment and professional services that are available to the community generally at nearby facilities.

My signature below shows that I am choosing to participate in this research project willingly. "Participation does not release the investigator(s), sponsor(s) or granting agency(ies) from their professional and ethical responsibility to me."

If you have any questions about this research project, feel free to contact:

Principal Investigator/Researcher: Pastor Jiwan S. Moon

26 Bryan Court

Kitchener, Ontario

Canada N2A $4 \mathrm{~J} 4$

Phone: 519-573-4320/Email: pastorismoon@gmail.com

By signing this form, I am stating that $I$ have read and understand the information above and I freely give my assent/consent to participate or permission for my child to participate in this mentoring and discipleship program.

Research Participant:

(Printed Name)

Signature:

Date Reviewed \& Signed

Parent/Guardian:

(Printed Name)

Signature:

Date Reviewed \& Signed.

Principal Investigator:

(Printed Name)

Signature:

Date Reviewed \& Signed 
APPENDIX K

FOLLOW ME ADVENTIST MOVEMENT

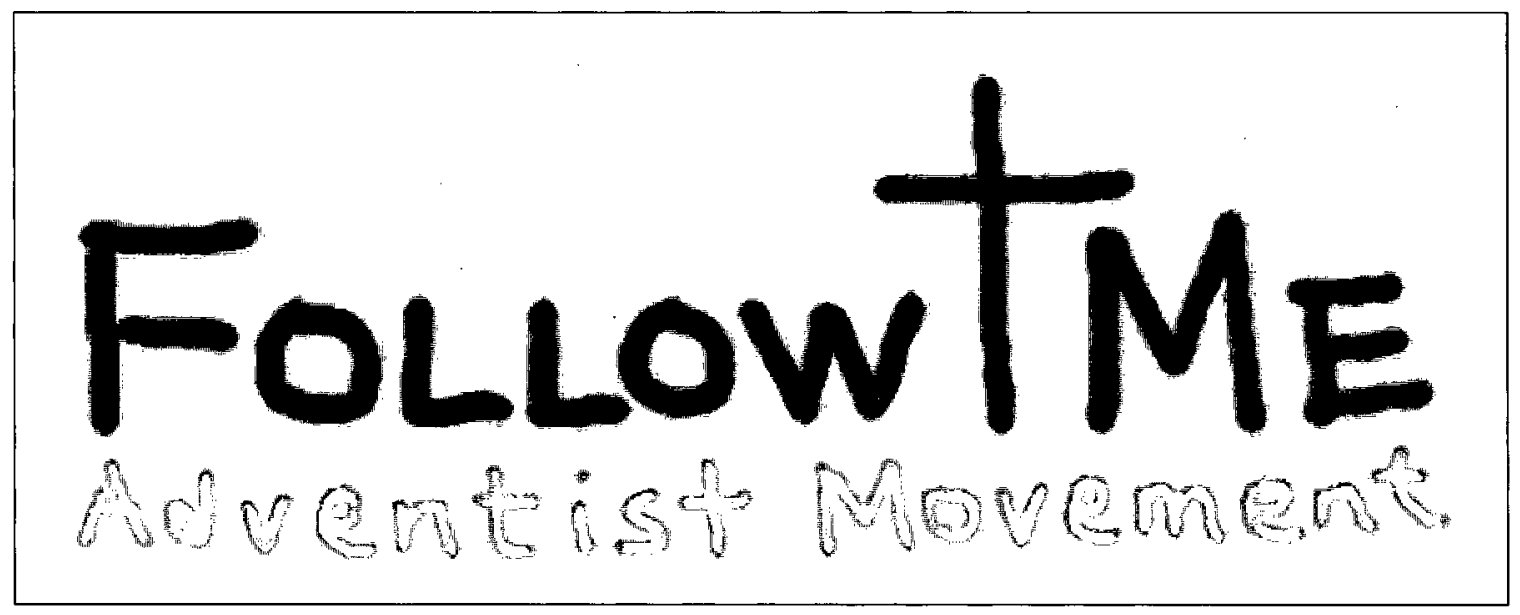




\section{REFERENCE LIST}

Adams, Gerald R., Montemayor, Raymond, \& Gullotta, Thomas. (1989). Biology of adolescent behavior and development. Newbury Park, CA: Sage.

Amsel, Eric, \& Renninger, K. Ann. (1997). Change and development: Issues of theory, method, and application. Mahwah, NJ: Lawrence Erlbaum Associates.

Balswick, Jack O., King, Pamela Ebstyne, \& Reimer, Kevin S. (2005). The reciprocating self: Human development in theological perspective. Downers Grove, IL: InterVarsity Press.

Beagles, Kathleen. (2009). The validity of the growing disciples in community model among adolescents in Seventh-day Adventist schools in North America. (Unpublished doctoral dissertation), Andrews University, Berrien Springs, MI.

Bee, Helen L. (1999). The growing child: An applied approach (2nd ed.). New York: Addison Wesley Longman.

Bell, Rob. (2005). Velvet Elvis: Repairing the Christian fiath. New York: HarperOne.

Berger, Kathleen Stassen. (1988). The developing person through the life span (2nd ed.). New York: Worth.

Berk, Laura E. (1998). Development through the lifespan. Boston, MA: Allyn and Bacon.

Berndt, Thomas J. (1997). Child development (2nd ed.). Madison, WI: Brown \& Benchmark.

Biehl, Bobb. (1996). Mentoring: Confidence in finding a mentor and becoming one. Nashville, TN: Broadman \& Holman.

Bjorklund, D. F. , \& Green, B. L. (1992). The adaptive nature of cognitive immaturity. American Psychologist, 47, 46-54.

Bonhoeffer, Dietrich. (1963). The cost of discipleship (Rev. ed.). New York: Macmillan.

Borgman, Dean. (2003). Hear my story: Understanding the cries of troubled youth. Peabody, MA: Hendrickson.

Bornstein, Marc H., \& Lamb, Michael E. (1999). Developmental psychology: An advanced textbook (4th ed.). Mahwah, NJ: Lawrence Erlbaum Associates. 
Brinthaupt, Thomas M., \& Lipka, Richard P. (2002). Understanding early adolescent self and identity: Applications and interventions. Albany, NY: State University of New York Press.

Burns, Jim, \& DeVries, Mike. (2001). The youth builder: Reach young people, strengthen families and change lives forever. Ventrual, CA: Gospel Light.

Capps, Donald. (2008). The decades of life: A guide to human development. Louisville, KY: Westminster John Knox Press.

Caspi, A., Lynam, D., Moffitt, T. E., \& Silva, P. A. (1993). Unraveling girls' delinquency: Biological, dispositional, and contextual contributions to adolescent misbehavior. Developmental Psychology, 29(19-30).

Chandler, M: J., Greenspan, S., \& Barenboim, C. (1973). Judgments of intentionality in response to videotaped and verbally presented moral dilemmas: The medium is the message. Child Development, 44, 315-320.

Chilton, Bruce. (2000). Rabbi Jesus: An intimate biography (1st ed.). New York: Doubleday.

Colarusso, Calvin A. (1992). Child and adult development: A psychoanalytic introduction for clinicians. New York: Plenum Press.

Csinos, David M. (2010). "Come follow me": Apprenticeship in Jesus' approach to education. Religious Education, 105(1), 45-62.

Dacey, John S., \& Travers, John F. (2004). Human development across the lifespan (Updated 5th ed.). Boston, MA: McGraw-Hill.

Dayringer, Richard. (2000). Life cycle: Psychological and theological perceptions. New York: Haworth Pastoral Press.

Dusek, Jerome B. (1991). Adolescent development and behavior (2nd ed.). Englewood Cliffs, NJ: Prentice Hall.

Eriksen, Karen. (2008). "Interpersonal" clients, students, and supervisees: Translating Robert Kegan. Counselor Education \& Supervision, 47(4), 233-248.

Erikson, Erik H. (1963). Childhood and society (2nd ed.). New York: Norton.

Erikson, Erik H. (1975). Life history and the historical moment. New York: Norton.

Fasick, Frank A. (1994). On the "invention" of adolescence. Journal of Early Adolescence, 14, 6-23.

Feldmeier, Peter. (2007). The developing Christian: Spiritual growth through the life cycle. Mahwah, NJ: Paulist Press. 
Fowler, James W. (1981). Stages of faith: The psychology of human development and the quest for meaning (1st ed.). San Francisco: Harper \& Row.

Frydenberg, Erica. (1997). Adolescent coping: Theoretical and research perspectives. New York: Routledge.

Frydenberg, Erica. (2008). Adolescent coping: Advances in theory, research, and practice. New York: Routledge.

Gilligan, Carol. (1982). In a different voice : psychological theory and women's development. Cambridge, Mass.: Harvard University Press.

Ginsburg, Herbert, \& Brandt, Sylvia Opper. (1988). Piaget's theory of intellectual development (3rd ed.). Englewood Cliffs, NJ: Prentice-Hall.

Goswami, Usha. (2002). Blackwell handbook of childhood cognitive development. Malden, MA: Blackwell.

Graber, Julia A., Brooks-Gunn, Jeanne, \& Petersen, Anne C. (1996). Transitions through adolescence: Interpersonal domains and context. Mahwah, $\mathrm{NJ}$ : Lawrence Erlbaum.

Grenell, Rene S. (2007). Adolescent behavior research studies. Hauppauge, NY: Nova Science.

Grueneich, R. (1982). Issues in the developmental study of how children use intention and consequence information to make moral evaluations. Child Development, 53, $29-43$.

Guest, Andrew M. (2009). Taking sides (2nd ed.). Boston, MA: McGraw Hill Higher Education.

Gumbiner, Jann. (2003). Adolescent assessment. Hoboken, NJ: J. Wiley \& Sons.

Harter, S., Whitesell, N. R. , \& Junkin, L. J. (1998). Similarities and differences in domain-specific and global self-evaluations of learning-disabled, behaviorally disordered, and normally achieving adolescents. American Educational Research Journal, 35, 653-680.

Hine, Thomas. (1999). The rise and fall of the American teenager. New York: Bard.

Howe, Neil, \& Strauss, William. (2000). Millennials rising : the next great generation/by Neil Howe and Bill Strauss; cartoons by R.J. Matson. New York: Vintage Books.

Inhelder, Barbel, \& Piaget, Jean. (1958). The growth of logical thinking from childhood to adolescence: An essay on the construction of formal operational structures. New York: Basic Books. 
Innes, Dick. (1985). I hate witnessing: A handbook for effective Christian communication. Ventura, CA: Regal Books.

Jankiewicz, Edyta, \& Jankiewicz, Darius. (2011). Let the little children come: Toward a Seventh-day Adventist theology of childhood. Andrews University Seminary Studies, 49(2), 213-242.

Kaplan, Louise J. (1984). Adolescence, the farewell to childhood. New York: Simon and Schuster.

Kegan, Robert. (1982). The evolving self: Problem and process in human development. Cambridge, MA: Harvard University Press.

Kegan, Robert. (1994). In over our heads: The mental demands of modern life. Cambridge, MA: Harvard University Press.

Kelcourse, Felicity Brock. (2004). Human development and faith: Life-cycle stages of body, mind, and soul. St. Louis, MO: Chalice Press.

Killgore, W. D., Oki, M., \& Yurgelun-Todd, D. A. (2001). Sex-specific developmental changes in amygdala responses to affective faces. Neuroreport, 12(2), 427-433.

King, Mike. (2006). Presence-centered youth ministry: Guiding students into spiritual formation. Downers Grove, IL: IVP Books.

King, P. E., \& Furrow, J. L. (2004). Religion as a resource for positive youth development: Religion, social capital, and moral outcomes. Developmental Psychology, 40(5), 703-713.

Krallmann, Günter. (2002). Mentoring for mission: A handbook on leadership principles exemplified by Jesus Christ (2nd ed.). Waynesburo, GA: Gabriel Pub.

Kreider, Larry. (2007). Authentic spiritual mentoring : nurturing younger believers toward spiritual maturity. Ventura, Calif.: Regal Books.

Lapsley, D. K. (1993). Toward an integrated theory of adolescent ego development: The "new look" at adolescent egocentrism. American Journal of Orthopsychiatry, 63, $562-571$.

Larson, R., \& Richards, M. H. (1991). Daily companionship in late childhood and early adolescence: Changing developmental contexts. Child Development, 62, 284-300.

Lee, Kang. (2000). Childhood cognitive development: The essential readings. Malden, MA: Blackwell.

Lefebvre, Solange, \& Ross, Susan A. (2007). Stages of life and Christian experience. London: SCM Press. 
Lerner, Richard M. (2002). Adolescence: Development, diversity, context, and application. Upper Saddle River, NJ: Prentice Hall.

Mallison, John. (1998). Mentoring to develop disciples and leaders. Melbourne: Scripture Union.

Marcia, James E. (1966). Development and validation of ego identity status. Journal of Personality and Social Psychology, 3, 551-558.

McDevitt, Teresa M., \& Ormrod, Jeanne Ellis. (2004). Child development: Educating and working with children and adolescents (2nd ed.). Upper Saddle River, NJ: Pearson/Merrill Prentice Hall.

Middendorf, Jon. (2000). Worship-centered youth ministry: A compass for guiding youth into God's story. Kansas City, MO: Beacon Hill Press of Kansas City.

Morra, Sergio, Gobbo, Camilla, Marini, Zopito, \& Sheese, Ronald. (2008). Cognitive development: Neo-Piagetian perspectives. New York: Lawrence Erlbaum Associates.

Mortimer, Jeylan T., \& Larson, Reed. (2002). The changing adolescent experience: Societal trends and the transition to adulthood. New York: Cambridge University Press.

Neudecker, Reinhard. (1999). Master-disciple/disciple-master relationship in Rabbinic Judaism and in the Gospels. Gregorianum, 80(2), 245-261.

Nichol, Francis D. (Ed.). (1978). The Seventh-day Adventist bible commentary. Washington: Review and Herald.

Novak, Gary, \& Pelaez, Martha B. (2004). Child and adolescent development: A behavioral systems approach. Thousand Oaks, CA: Sage Publications.

Parrott, Les. (2000). Helping the struggling adolescent: A guide to thirty-six common problems for counselors, pastors, and youth workers (Updated and expanded. ed.). Grand Rapids, MI: Zondervan.

Peterson, Eugene H. (1994). Like dew your youth: Growing up with your teenager. Grand Rapids, MI: W.B. Eerdmans.

Phipps, William E. (1993). The wisdom \& wit of Rabbi Jesus (1sț ed.). Louisville, KY: Westminster/John Knox Press.

Piaget, Jean. (1954). The construction of reality in the child. New York: Basic Books.

Pressley, Michael, \& McCormick, Christine. (2007). Child and adolescent development for educators. New York: Guilford Press. 
Richardson, Ken, Sheldon, Sue, \& University, Open. (1990). Cognitive development to adolescence: A reader. East Sussex, U.K.: Lawrence Erlbaum Associates in association with the Open University.

Samra, James G. (2003). A biblical view of discipleship. Bibliotheca Sacra, 160(AprilJune), 219-234.

Scales, Peter. (2003). Other people's kids: Social expectations and American adults' involvement with children and adolescents. New York: Kluwer Academic/Plenum.

Schickedanz, Judith A. (1998). Understanding children and adolescents (3rd ed.). Boston: Allyn and Bacon.

Siegel, Linda S., \& Brainerd, Charles J. (1978). Alternatives to Piaget: Critical essays on the theory. New York: Academic Press.

Siegler, Robert S., DeLoache, Judy S., \& Eisenberg, Nancy. (2006). How children develop (2nd ed.). New York: Worth.

Steinberg, Laurence D. (1985). Adolescence (1st ed.). New York: Knopf.

Steinberg, Laurence D. (1996). Adolescence (4th ed.). New York: McGraw-Hill.

White, Ellen Gould Harmon. (1890). Patriarchs and prophets. Battle Creek, MI: Review and Herald

White, Ellen Gould Harmon. (1893). Christian education. Battle Creek, MI: International Tract Society.

White, Ellen Gould Harmon. (1898). The desire of ages. Oakland, CA: Pacific Press.

White, Ellen Gould Harmon. (1905). The ministry of healing. Mountain View, Calif.,: Pacific press publishing association.

White, Ellen Gould Harmon. (1911). The acts of the apostles in the proclamation of the gospel of Jesus Christ. Mountain View, CA: Pacific Press.

White, Ellen Gould Harmon. (1954). Child guidance: Counsels to Seventh-day Adventist parents as set forth in the writings of Ellen $G$. White. Nashville, TN: Southern

White, Ellen Gould Harmon. (1970). Conflict and courage. Washington: Review and Herald.

White, Ellen Gould Harmon. (1985). Reflecting Christ. Washington: Review and Herald

White, Ellen Gould Harmon. (1988). The voice in speech and song: As set forth in the writings of Ellen $G$. White. Boise, ID: Pacific Press. 
White, Ellen Gould Harmon. (1990). The retirement years. Washington, DC: Review and Herald Pub. Association.

Wimberly, Edward P. (2000). Relational refugees: Alienation and reincorporation in African American churches and communities. Nashville, TN: Abingdon Press.

Wood, David J. (1998). How children think and learn: The social contexts of cognitive development (2nd ed.). Malden, MA: Blackwell.

Woody, Robert Henley. (2011). Helping children and adolescents: Evidence-based strategies from developmental and social psychology. Cambridge, MA: Hogrefe.

Young, Brad. (2007). Meet the rabbis: Rabbinic thought and the teachings of Jesus. Peabody, MA: Hendrickson.

Yuill, N., \& Perner, J. (1988). Intentionality and knowledge in children's judgments of actor's responsibility and recipent's emotional reaction. Developmental Psychology, 24, 358-365. 
VITA 


\section{VITA}

NAME:

DATE OF BIRTH:

PLACE OF BIRTH:

MARRIED:

CHILDREN:

EDUCATION:

\section{EDUCATION:}

Jiwan Stefan Moon

February 20, 1969

Seoul, Korea

June 6, 2006 to Jessica (Escorcio) Moon

Hannah Moon (May 20, 2007), Rebecca Anna Moon

(March 7, 2010), and Isabella Jinah Moon (April 14, 2012).

$2006-2014$

D. Min. in Youth \& Young Adult Ministry

Andrews University SDA Theological Seminary

$2005-2006$

M. A. in Youth \& Young Adult Ministry

Andrews University SDA Theological Seminary

$1997-1999$

M. Div. Emphasis in Youth Ministry

Andrews University SDA Theological Seminary

$1994-1997$

B. A. in Religious Studies, Minor in Practical Theology Southern Adventist University

$1986-1990$

B. A. in Theology

Adventist University of the Philippines

Received the most outstanding international student award for the year 1989 from the secretary of the Department of Education, Culture, and Sports of the Philippines.

\section{ORDINATION:}

July 12, 2003

\section{EXPERIENCE:}

$2014-$

Associate Youth Ministries Director / Director of Public Campus Ministries

General Conference of Seventh-day Adventists, Maryland 
Senior Pastor

Harmony SDA Church, Ontario, Canada

Toronto Italian SDA Company, Ontario, Canada

$2002-2013$

Senior Pastor

Kitchener-Waterloo SDA Church, Ontario, Canada

1998 - $2002 \quad$ Youth Pastor

Toronto Korean SDA Church, Ontario, Canada

1996 - $1997 \quad$ Youth Pastor

Hacienda Korean SDA Church, California

1995 - $1996 \quad$ Youth Pastor

Atlanta Korean SDA Church, California

$1993-1994$

Youth Pastor

Maryland Korean SDA Church, Maryland

$1993-1994$

Youth Pastor

Cerritos Korean SDA Church, California

\section{PROFESSIONAL CONTRIBUTIONS:}

$2013-$

$2008-2012$

2012

$2012-$

$2009-2013$

2009

2008
President \& Co-Founder, Disaster Relief Chaplains of Canada (DRCC)

180 Symposium (Center for Youth Evangelism) presenter

REASON Symposium (Campus Ministries, Andrews University) presenter

President \& Founder, Follow Me Adventist Movement (FMAM)

Chair, Southern Ontario Adventist Camp Meeting, Ontario, Canada

Co-contributor of Reach Youth Campus, Reach the World (Edited by Steve Case)

Co-contributor of Ministering with Millennials (Edited by Roger Dudley with Allan Walshe) 
$2007-$

$2006-$

$2005-2007$

$2000-2002$

\section{CERTIFICAITONS:}

2010

2013
President \& Co-Founder, Reach-Out \& Care Missionary Movement (ROCMM)

President, Asia-Pacific Adventist Workers Association (APAWA), Ontario, Canada

President, Southern Ontario Adventist Ministerial Association, Ontario, Canada

Executive Secretary/Vice-President, GTA (Greater Toronto Area) Adventist Ministerial Association, Ontario, Canada

Pathfinder Master Guide (Ontario Conference of the Seventh-day Adventist Church)

Disaster Relief Chaplaincy (ICISF-International Critical Incident Stress Foundation)

SKILLS \& HOBBIES:

Bilingual (English, Korean) who understands Tagalog (National Language of the Philippines).

Play violin, guitar, bassoon, and piano.

Love to play all sports, especially soccer. 